Florida State University College of Law

Scholarship Repository

Scholarly Publications

$12-2005$

\title{
Horizontal Federalism in an Age of Criminal Justice Interconnectedness
}

Wayne A. Logan

Florida State University College of Law

Follow this and additional works at: https://ir.law.fsu.edu/articles

Part of the Constitutional Law Commons, and the Criminal Law Commons

\section{Recommended Citation}

Wayne A. Logan, Horizontal Federalism in an Age of Criminal Justice Interconnectedness, 154 U. PA. L. REV. 257 (2005),

Available at: https://ir.law.fsu.edu/articles/187

This Article is brought to you for free and open access by Scholarship Repository. It has been accepted for inclusion in Scholarly Publications by an authorized administrator of Scholarship Repository. For more information, please contact efarrell@law.fsu.edu. 


\section{University of Pennsylvania Law Review \\ FOUNDED 1852 \\ Formerly American Law Register}

\section{ARTICLES

\author{
WAYNE A. LOGAN ${ }^{\dagger}$
} \\ INTRODUCTION}

HORIZONTAL FEDERALISM IN AN AGE OF CRIMINAL JUSTICE INTERCONNECTEDNESS

A central precept in American governance is that states should be afforded latitude to pursue their own course in social and economic matters. With such autonomy, as famously recognized by Justice Brandeis, the states can serve as "laborator[ies]," enjoying the freedom to undertake "experiments without risk to the rest of the country." States, ideally, can thereby also better legislate in a fashion con-

\footnotetext{
† Professor of Law, William Mitchell College of Law. Special thanks to Markus Dubber, Stuart Green, Sandra Guerra-Thompson, David Logan, Michael O'Hear, Mark Rosen, Kevin Washburn, and Ron Wright for comments and suggestions; Meg Daniel for editorial support; and Brad Endicott and Carl Nowlin for research assistance.

${ }^{1}$ New State Ice Co. v. Liebmann, 285 U.S. 262, 311 (1932) (Brandeis, J., dissenting).
} 
sistent with the views of their citizens, ${ }^{2}$ permitting a healthy democratic pluralism to flourish, which in turn allows individuals to "vote with their feet" ${ }^{3}$ and increases governmental responsiveness by "putting the States in competition for a mobile citizenry."

Since the Framing Era, diversity has marked state civil ${ }^{5}$ and criminal $^{6}$ law alike, at once shaping and reflecting local norms and practices. Consistent with the tenets of "fifty-labs" federalism, ${ }^{7}$ and the Supreme Court's abiding reluctance to regulate state criminal law ${ }^{8}$

${ }^{2}$ See Gregory v. Ashcroft, 501 U.S. 452, 458 (1991) (“[Federalism] assures a decentralized government that will be more sensitive to the diverse needs of a heterogenous society; it increases opportunity for citizen involvement in democratic processes . ...”); Evan H. Caminker, State Sovereignty and Subordinacy: May Congress Commandeer State Officers To Implement Federal Law?, 95 Colum. L. REv. 1001, 1074 (1995) (asserting that federalism permits "greater local tailoring and aggregate diversity of policies throughout the nation").

${ }^{3}$ The concept derives from the seminal work of Charles Tiebout, who, analogizing from behaviors in consumerist private markets, reasoned that individuals in a federalist system will gravitate to jurisdictions that best serve their personal needs and convictions. See Charles M. Tiebout, A Pure Theory of Local Expenditures, 64 J. POL. ECON. 416, 418-19 (1956) ("[T] he consumer-voter moves to that community whose local government best satisfies his set of preferences. The greater the number of communities and the greater the variance among them, the closer [he] will come to fully realizing his preference position."). For more on Tiebout's work as it applies to criminal law variations among the states, see infra note 360 and accompanying text.

${ }^{4}$ Gregory, 501 U.S. at 458; see also Michael W. McConnell, Federalism: Evaluating the Founders' Design, 54 U. CHI. L. REV. 1484, 1504 (1987) ("The liberty that is protected by federalism is not the liberty of the apodictic solution, but the liberty that comes from diversity coupled with mobility.").

${ }^{5}$ See, e.g., Betsy J. Grey, The New Federalism Jurisprudence and National Tort Reform, 59 WASH. \& LEE L. REV. 475, 513-18 (2002) (discussing variations in state tort law).

${ }^{6}$ See Rochin v. California, 342 U.S. 165, 168 (1952) ("[C] rimes in the United States are what the laws of the individual States make them ....”).

${ }^{7}$ See Heath v. Alabama, 474 U.S. 82, 93 (1985) ("The Constitution leaves in the possession of each State 'certain exclusive and very important portions of sovereign power.' Foremost among the prerogatives of sovereignty is the power to create and enforce a criminal code." (quoting THE FEDERALIST NO. 9, at 55 (Alexander Hamilton) (J.E. Cooke ed., 1961))). Of late, this deference has been most manifest in decisions by the Court to invalidate federal laws seen as unduly intruding upon state criminal law prerogatives. See, e.g., United States v. Lopez, 514 U.S. 549, 551 (1995) (invalidating a federal law prohibiting firearm possession on school premises or within a 1000-foot radius of a school because the law lacked a sufficient nexus with federal concerns under the Commerce Clause); $c f$. United States v. Morrison, 529 U.S. 598, 627 (2000) (invalidating a federal law allowing civil damages for victims of gendermotivated violence).

${ }^{8}$ See William J. Stuntz, The Uneasy Relationship Between Criminal Procedure and Criminal Justice, 107 YALE L.J. 1, 54 (1997) ("Constitutionally speaking, substantive criminal law is almost entirely unregulated.”). Two noteworthy exceptions to this historic solicitude can be found in the Court's recent controversial decisions in Lawrence $v$. Texas, 539 U.S. 558, 578 (2003) (invalidating a Texas law criminalizing consensual homosex- 
and its attendant sanctions, ${ }^{9}$ states continue to evince diverse views on criminal law matters in particular. One sees disagreement on such basic matters as whether particular behavior should be criminalized; ${ }^{10}$ the definitions of criminal offenses; $;^{11}$ the availability of defenses $;{ }^{12}$ punishments ${ }^{13}$ and the means by which they are determined $;{ }^{14}$ resort to imprisonment (versus community-based sanctions) $;^{15}$ and even the rationales justifying punishment. ${ }^{16}$

Diversity also exists in the rights and procedures marking state criminal justice systems. While the Constitution's Supremacy Clause

ual sodomy), and Gonzales v. Raich, 125 S. Ct. 2195, 2212 (2005) (invalidating a California law decriminalizing the medical use of marijuana).

${ }^{9}$ See Ewing v. California, 538 U.S. 11, 28 (2003) (stating that the Supreme Court does not sit as a "superlegislature" to "second-guess" punishment decisions of state legislatures); Rummel v. Estelle, 445 U.S. 263, 285 (1980) (noting that parameters of recidivist enhancement laws "are matters largely within the discretion of the punishing jurisdiction").

${ }^{10}$ See, e.g., Michael M. O'Hear, Federalism and Drug Control, 57 VAND. L. REv. 783, 821 (2004) (noting varied state views on criminalizing possession of small amounts of marijuana); Amy C. Radosevich, Note, Thwarting the Stalker: Are Anti-Stalking Measures Keeping Pace with Today's Stalker?, 2000 U. ILL. L. REV. 1371, 1381-85 (2000) (noting that some states have enacted anti-stalking laws and that there is significant variation among existing statutes). For a discussion of other historic examples of state diversity, concerning such matters as prostitution and polygamy, see Wayne A. Logan, Criminal Law Sanctuaries, 38 HARV. C.R.-C.L. L. REV. 321, 367-68 (2003).

${ }^{11}$ See, e.g., Iris Bennett, Note, The Unconstitutionality of Nonuniform Immigration Consequences of "Aggravated Felony" Convictions, 74 N.Y.U. L. REV. 1696, 1720-29 (1999) (discussing substantive variations in state definitions of statutory rape, assault and battery, petty theft, and driving under the influence). This diversity, in turn, is augmented by political subunits of state governments-municipalities-which enjoy authority to regulate criminal behaviors. See Wayne A. Logan, The Shadow Criminal Law of Municipal Governance, 62 OHIO ST. L.J. 1409, 1421-38 (2001) (discussing the authority of municipalities to enact penal laws as a result of their home rule powers).

${ }^{12}$ See, e.g., 2 PAul H. Robinson, CRiminal LAW Defenses $\$ § ~ 171-194$ (1984 \& Supp. 2005) (surveying state variations in excuse-related defenses).

${ }^{3}$ As the Supreme Court has noted, "the classification of state crimes differs widely among the States." Welsh v. Wisconsin, 466 U.S. 740, 754 n.14 (1984). Compare, e.g., MINN. STAT. ANN. §§ 152.01(16), .027(4) (West 2005) (punishing possession of more than 42.5 grams of marijuana as a petty misdemeanor), with N.D. CENT. CODE $§ 19-$ 03.1-23(6) (Supp. 2005) (punishing such possession as a felony). For a comprehensive overview of differences in state drug laws, see GALE GROUP, NATIONAL SURVEY OF STATE LAws 163-200 (Richard A. Leiter ed., 4th ed. 2003).

${ }^{14}$ See, e.g., Kevin R. Reitz, The Disassembly and Reassembly of U.S. Sentencing Practices, in SENTENCING AND SANCTIONS IN WESTERn CounTRIES 222, 226-27 (Michael Tonry \& Richard S. Frase eds., 2001) (noting variations in state sentencing guideline systems).

${ }^{15}$ See Kevin R. Reitz, The Federal Role in Sentencing Law and Policy, 543 ANnALS AM. ACAD. POL. \& SOC. SCI. 116, 125 (1996) (demonstrating that state-level incarceration rates vary by a factor of seven).

${ }^{16}$ See Geraldine Szott Moohr, The Federal Interest in Criminal Law, 47 SYRACUSE L. REV. 1127, 1132 n.20 (1997) (discussing differing state penal rationales). 
requires that states, at a minimum, provide their citizens with rights prescribed by federal law, ${ }^{17}$ the states of course are free to extend more protections ${ }^{18}$ and otherwise operate their criminal justice systems largely free of federal dictate. ${ }^{19}$

This Article examines some of the challenges bred by this diversity, which, rather than deriving from the frequently clashing competitive interests of states,$^{20}$ result from the states' increasing interconnection in criminal justice matters. Two foremost examples of this phenomenon are examined here: criminal recidivist sentence enhancement laws and sex offender registration laws. Both types of laws have been in effect in some form for decades and have evolved over time to accommodate ex-offenders, who, consistent with constitutional freedom of movement, change state residences. With these refinements, the states have sought to prohibit such individuals from escaping continued accountability for their past wrongdoing ${ }^{21}$ and deprive them of an incentive to migrate elsewhere in search of a "clean slate." ${ }^{22}$ As President Clinton warned when signing federal leg-

${ }^{17}$ See Lynn A. Baker \& Ernest A. Young, Federalism and the Double Standard of Judicial Review, 51 DUKE L.J. 75, 149 (2001) (observing that state experimentation with constitutional rights "is limited by a 'floor' of basic federal constitutional guarantees").

${ }^{18}$ See PruneYard Shopping Ctr. v. Robins, 447 U.S. 74, 81 (1980) (stating that federal law does not "limit the authority of the State to exercise its police power or its sovereign right to adopt in its own Constitution individual liberties more expansive than those conferred by the Federal Constitution").

${ }^{19}$ See, e.g., MARTIN R. GARDNER, Understanding JUVEnile LaW 189-206 (2d ed. 2003) (surveying the broad latitude of states in the operation of their juvenile justice systems). This is so despite the increasing imposition of federal constitutional strictures, first as a result of pro-defendant Warren Court holdings, and later as a result of pro-prosecution holdings of the Burger and Rehnquist Courts. For more on the states' "lively" role and "fervent self-determination" in criminal justice policy, see Ronald F. Wright, How the Supreme Court Delivers Fire and Ice to State Criminal Justice, 59 WASH. \& LEE L. REV. 1429, 1430, 1457 (2002).

${ }^{20}$ As Paul Freund noted over fifty years ago, "[a] federal system presupposes diversity and must cope with corresponding tensions." Paul A. Freund, Umpiring the Federal System, 54 COLUM. L. REV. 561, 561 (1954).

${ }^{21}$ See People v. Johnson, 39 Cal. Rptr. 2d 463, 470 (Ct. App. 1995) (endorsing the goal of "attacking the recidivism of violent sex offenders by providing for longer enhancements for prior convictions ... irrespective of where, or in which jurisdiction, the prior crimes were perpetrated").

${ }^{22}$ See State v. Hulbert, 544 S.E.2d 919, 923-24 (W. Va. 2001) (asserting that failure to consider foreign convictions in recidivist determinations would "invite" ex-offenders to enter the state in search of a "clean slate,' thereby enabling them to continue committing [crimes] in [the] state... without realizing the legislatively-intended effects of enhanced punishment for repeat offenders"); see also, e.g., Alison Bath, Sex Criminals Flocking to Nevada, ReNo GAZETTE-J., Sept. 26, 2004, at 8H, available at http://www.infoweb.newsbank.com (follow "America's Newspapers" hyperlink to 
islation authorizing a national sex offender registry for the use of law enforcement: "If you dare to prey on our children, the law will follow you wherever you go-state to state, town to town." ${ }^{23}$

The Article begins with an overview of the means by which recidivist enhancement and registration laws take account of out-of-state prior convictions, critically important matters largely ignored by commentators. ${ }^{24}$ While state courts often face challenges in applying recidivist and registration laws to indigenous offenders, their task is made considerably more difficult when the predicate convictions occurred elsewhere. In such situations, courts must interpret and apply the law of another state to determine if the conviction, itself possibly aged or marked by ambiguous or incomplete information, warrants consideration under their recidivist or registration law. Part I of this Article examines the two basic approaches-external and internalthat jurisdictions use to make such determinations. The internal approach requires that out-of-state convictions, and any punishment resulting from those convictions, satisfy the eligibility requirements of the forum state's registration or recidivist enhancement law. The external approach, on the other hand, allows such decisions to be based on the legal determinations of the forum state's fellow sovereigns.

\footnotetext{
"Reno Gazette-Journal" hyperlink) (noting local concern over the perceived "mass exodus by sex offenders" to Nevada because of lax registration laws and enforcement).

${ }^{23}$ Ron Fournier, Clinton Signs Law on Sex Offenders, CHI. Sun-Times, May 18, 1996, at 12; see also Brian McGrory, Clinton Sets Tracking of Sex Offenders, Boston GLOBE, Aug. 25, 1996, at A1 (quoting President Clinton's intent in signing the law: "to keep track of [sex offenders] . . . not just in a single state, but wherever they go . . so that parents and police have the warning they need to protect our children .... . Deadly criminals don't stay within state lines, so neither should law enforcement's tools to stop them"). Currently, the U.S. Department of Justice coordinates "a nationwide, Internet-based, searchable National Sex Offender Public Registry website," which promises "one-stop access to registries from all 50 states and the District of Columbia by the end of the year." U.S. Dep't of Justice, National Sex Offender Public Registry, http://www.nsopr.gov (last visited Nov. 15, 2005).

${ }^{24}$ With respect to recidivist enhancements, the literature contains only a single entry, a brief descriptive account by a student commentator published over a decade ago. See Richard A. Galt, Comment, The Use of Out-of-State Convictions for Enhancing Sentences of Repeat Offenders, 57 ALB. L. REv. 1133 (1994). State interconnection relative to registration has been wholly ignored, with commentators focusing instead on the many constitutional and policy implications of registration itself. See, e.g., James R. Acker \& Catherine Cerulli, When Answers Precede Questions: Megan's Law's Uncertain Policy Consequences, 34 CRIM. L. BULl. 235, 240-58 (1998) (discussing the public policy consequences of the enforcement of registration laws); Wayne A. Logan, Liberty Interests in the Preventive State: Procedural Due Process and Sex Offender Community Notification Laws, 89 J. CRIM. L. \& CRIMINOLOGY 1167, 1177-82 (1999) (examining the procedural due process issues potentially presented by registration and notification).
} 
Part II explores the ramifications of interconnection and states' use (or non-use) of one another's criminal justice outcomes. These ramifications assume practical and theoretical form, and vary in accordance with states' adoption of the internal or external approach. In terms of the practical ramifications, the internal approach poses particular analytic challenges because states often must undertake a difficult interstate exercise in statutory construction. Because the approach places premium importance on the forum's legal norms, without deference to how the prior conviction was treated in the other state, it is not uncommon for individuals to escape continued accountability. This very uncertainty, however, can raise notice concerns for immigrants who must fathom (with respect to registration laws, often in a very short time period) the legal consequences of their prior conviction in their newly adopted state. Such concerns are not as pronounced in states using an external approach because, as noted, such legal consequences are predetermined by the individual's erstwhile state of residence.

The external approach, however, results in a consequence of a different sort: unequal treatment of otherwise similarly situated individuals. Because registration and recidivist enhancement outcomes are allowed to hinge on how another state would resolve the question, individuals hailing from especially punitive states can suffer differentially compared both to their counterparts who enter the forum with convictions from less punitive states and to those indigenous to the forum. For individuals, the geographic happenstance of their criminal history in effect determines their destiny. For society as a whole, states' at times extreme criminal law positions are permitted to ripple across not just space but also time, because recidivist and registration laws consider convictions from years before, allowing perhaps draconian and retrograde mores to be frozen in amber and given ongoing, contemporary effect.

Even more intriguing are the theoretical implications of state interconnection, examined in Part III. Internal approach states can be seen as stalwarts of "fifty-labs" federalism. They make their own calls on recidivist and registration eligibility, and resist the characterizations afforded convictions by other states, thereby giving effect to state autonomy and diversity. External approach states, on the other hand, place premium importance on uniformity and comity. Their deferential approach, in addition to depriving the nation of a "lab," has a number of subtle yet significant collateral consequences. These include the following: the deflection of political responsibility for the 
adoption of criminal law norms, which themselves might otherwise not garner sufficient political support in the forum; the skewing of the ostensibly local character of the criminal law; and the removal of incentives for "laggard" states to conform their laws to the standards of their more progressive peers, possibly contributing to a "race to the bottom." Finally, with more uniformity and less experimentation come diminished prospects for democratic competition, with attendant negative effects on the constitutional right of free travel.

Whatever its benefits, criminal justice interconnection has major practical and theoretical implications for "our federalism," ${ }^{25}$ which have gone unaddressed. While courts and commentators have focused intensely upon federal-state interrelations in criminal justice matters,${ }^{26}$ and "vertical" federalism more generally, ${ }^{27}$ scant attention has been paid to the interactions among the states, or "horizontal" federalism, ${ }^{28}$ notwithstanding the reality that states process the lion's share of U.S. criminal offenders. ${ }^{29}$ As the ensuing discussion makes clear, as the states determine the fate of immigrant offenders, they are laying bare many of the benefits and pitfalls of diversity (and uniform-

${ }^{25}$ See United States v. Lopez, 514 U.S. 549, 581 (1995) (Kennedy, J., concurring) (lauding "the theory and utility of our federalism"); see also Younger v. Harris, 401 U.S. $37,44-45$ (1971) (propounding the benefits of a federalist system).

${ }^{26}$ For a sample of the voluminous (and ever-expanding) commentary on federalization, most of it highly critical, see, for example, Kathleen F. Brickey, Criminal Mischief: The Federalization of American Criminal Law, 46 HASTINGS L.J. 1135 (1995); Steven D. Clymer, Unequal Justice: The Federalization of Criminal Law, 70 S. CAL. L. Rev. 643 (1997).

${ }^{27}$ Federalism, of course, has always admitted of different meanings. This Article borrows from a definition provided by Roderick Hills: federalism is taken to mean "the delegation of governmental powers to territorially limited governments within a nation [where] the policymakers of the limited governments are elected by the persons residing within those governments' jurisdictions." Roderick M. Hills, Jr., The Political Economy of Cooperative Federalism: Why State Autonomy Makes Sense and "Dual Sovereignty” Doesn't, 96 MiCH. L. REv. 813, 815 n.3 (1998).

${ }_{28}$ On the horizontal and vertical characterizations of federalism more generally, see Dan L. Burk, Federalism in Cyberspace, 28 CONN. L. REV. 1095, 1100 (1996) (noting that in our federalist system, "power is divided 'vertically' between the states and the federal government and 'horizontally' among the several states"). Horizontal federalism, of course, is susceptible of federal-centric application and definition as well. See L. Harold Levinson, The Legitimate Expectation that Public Officials Will Act Consistently, 46 AM. J. COMP. L. 549, 551-52 (1998) (explaining that horizontal federalism can also refer to the relationship between and among the legislative, executive, and judicial branches of the federal government).

${ }^{29}$ See 1 Wayne R. LaFave et al., Criminal Procedure $§ 1.2$ (b) (1999 \& Supp. 2005) (characterizing the federal criminal justice system as a "bit player" compared to the states and citing data in support (internal quotation marks omitted)). 
ity) in a federal republic whose constituent criminal justice systems are increasingly marked by interconnectedness.

\section{THE MECHANICS OF INTERCONNECTION}

U.S. jurisdictions have only comparatively recently evinced a sensitivity to criminal law outcomes in sister states. Indeed, historically, states readily indulged their power to physically banish offenders in the interest of territorial purification, regardless of the negative effects on their fellow sovereigns. ${ }^{30}$ By the 1930 s, however, states came to recognize the folly of shuttling their unwanted among themselves and began to make common enterprise in handling criminal offenders. ${ }^{31}$ During this time crime also ascended to prominence as a problem of national proportion, ${ }^{32}$ prompted in large part by anxiety over the increasing mobility of criminal offenders. ${ }^{33}$ In 1934, states entered into the first interstate compacts allowing for the monitoring of itinerant

${ }^{30}$ See James Grahame, Progress of the Colonies: The Persecution of the Quakers, in $1 \mathrm{THE}$ GREAT REPUBlic BY THE MASTER HiSTORIANS 217, 219-21 (Charles Morris ed., 1912) (describing the use of banishment in the colonial era); Matthew D. Borrelli, Note, Banishment: The Constitutional and Public Policy Arguments Against This Revived Ancient Punishment, 36 SUFFOLK U. L. REV. 469, 469-86 (2003) (surveying more modern use of banishment).

For a discussion of modern-day expulsionist impulses, predicated on the natural competitive zeal of states to "out-tough" one another in their crime control efforts, see Doron Teichman, The Market for Criminal Justice: Federalism, Crime Control, and Jurisdictional Competition, 103 MiCH. L. REv. 1831, 1849-57 (2005). For a rebuttal, based in part on the evidence advanced here, see Wayne A. Logan, Crime, Criminals and Competitive Crime Control, 104 Mich. L. REV. (forthcoming 2006).

${ }^{31}$ See, e.g., People v. Baum, 231 N.W. 95, 96 (Mich. 1930) (concluding that banishment "tend $[\mathrm{s}]$ to incite dissension, provoke retaliation, and disturb that fundamental equality of political rights among the several states which is the basis of the Union itself").

32 See LaWrence M. Friedman, Crime And Punishment in American History 273 (1993) (identifying Herbert Hoover's 1929 inaugural address as the genesis of crime being viewed as a "national issue").

${ }^{33}$ See id. at 266 ("Crime had become interstate... Twentieth century criminals had wheels and wings.”); Francis H. Bohlen \& Harry Shulman, Arrest With and Without a Warrant, 75 U. PA. L. REV. 485, 491-92 (1927) ("People no longer live their whole lives in the village in which they were born."). During this era, Congress also awakened to the problems presented by the increasing mobility of criminal offenders, prompting a surge in federal criminal laws covering behavior previously the exclusive focus of states. See Jerome v. United States, 318 U.S. 101, 102 (1943) (noting that "[b]y 1934 great concern had been expressed over interstate operations by gangsters against banksactivities with which local authorities were frequently unable to cope," and noting new federal legislation to address the concern). 
ex-offenders and the continued accountability of absconders. ${ }^{34}$ In 1935, the Interstate Commission on Crime was established in the name of enhancing intergovernmental cooperation in crime control. The "interstate criminal was the first target for attack," and the Commission worked to address "loopholes ... in criminal law administration which aided the 'commuting criminal' . . while at the same time handicapping police and law enforcement officials." ${ }^{35}$

Today, faced with an increasingly mobile citizenry, ${ }^{36}$ states have even more reason to be mindful of how their fellow sovereigns handle criminal offenders, despite the challenges often presented ${ }^{37}$ and the competitive impulses frequently marking interstate relations. ${ }^{38}$ This Part examines two specific instances of such interconnection: the use

${ }^{34}$ See Deborah A. Hansen, State Efforts Toward National Crime Control, 63 J. ST. GOV'T 72, 72-73 (1990) (discussing the development of the Compact for the Supervision of Parolees and Probationers). Until Congress enacted the Crime Control Consent Act of 1934, states were forbidden from entering into formal crime control agreements of a coordinated nature. Id. at 73 (citing Virginia v. Tennessee, 148 U.S. $503,517-20$ (1893), which prohibited interstate compacts that would affect the political balance of the federal system). For a discussion of the emergence of compacts during this period more generally, see Felix Frankfurter \& James M. Landis, The Compact Clause of the Constitution-A Study in Interstate Adjustments, 34 YALE L.J. 685, 695-98 (1925).

For the modern incarnation of the Interstate Compact for the Supervision of Adult Offenders, see 4 U.S.C. $§ 112$ (a) (2000) ("The consent of Congress is hereby given to any two or more States to enter into agreements or compacts for cooperative effort and mutual assistance in the prevention of crime and in the enforcement of their respective criminal laws and policies ...."). As of 2003, forty-eight states and the District of Columbia had adopted the Compact. Michael L. Buenger \& Richard L. Masters, The Interstate Compact on Adult Offender Supervision: Using Old Tools to Solve New Problems, 9 ROGER Williams U. L. REV. 71, 73 (2003).

${ }^{35}$ INTERSTATE COMM'N ON CRIME, A REPORT OF ACTIVITIES FOR THE YEAR ENDING DECEMBER 31, 1937, at 3 (1937). The loopholes fell into "three natural categoriesapprehension, prosecution, trial, and punishment." Id. To this end, in 1935 the Commission drafted uniform reciprocal acts for state adoption, allowing for expanded interstate cooperation in the areas of fresh pursuit, extradition, witness rendition, and parole and probation supervision. Id. at 4-6.

${ }^{36}$ According to the 2000 Census, an estimated 8.4 million Americans changed state residences during the preceding twelve-month period. U.S. CENSUS BUREAU, ANNUAL GeOgRAPHICAL MOBILITy RATES, By TyPE OF MOVEMENT: 1947-2003, at 1 tbl.A-1 (2004), http://www.census.gov/population/socdemo/migration/tab-a-1.pdf. On the issue of criminal mobility more generally, see Joseph Deutsch et al., Interjurisdictional Criminal Mobility: A Theoretical Perspective, 21 URB. STUD. 451 (1984).

${ }^{37}$ See People v. Parker, 359 N.E.2d 348, 350 (N.Y. 1976) (“[C] rimes committed in other jurisdictions ... with differing social mores and standards of conduct take on added significance in our highly mobile society.").

${ }^{38}$ On the development of cooperative norms in otherwise competitive or combative environs more generally, see ROBERT AXELROD, THE EVOLUTION OF COOPERATION 3 (1984); PAUl E. PETERSON ET AL., WHEN FEDERALISM WORKS 6 (1986). 
of prior out-of-state convictions to (1) enhance the prison terms of offenders convicted of a new crime in the forum state and (2) require that newly arrived individuals comply with the forum's sex offender registration requirements.

\section{A. Criminal Recidivist Laws}

\section{Historical Background}

Although recidivism has been called "a traditional, if not the most traditional, basis for a sentencing court's increasing an offender's sentence," ${ }^{, 39}$ and prior offenses have been used to enhance sentences in the United States since the seventeenth century, ${ }^{40}$ recidivist laws traditionally paid little heed to foreign prior offenses. ${ }^{41}$ Indeed, there was scant need to do so given that criminal activity itself was largely a local phenomenon. ${ }^{42}$ In addition to this lack of practical need, states remained wary of the wide procedural variations distinguishing the criminal justice systems of individual states. Writing in 1934, for instance, the Georgia Supreme Court invoked such differences in support of its decision to exclude foreign convictions from consideration when the Georgia recidivist statute made no reference to them:

The courts of Georgia do not take judicial cognizance of the laws of these foreign jurisdictions, and therefore we cannot attribute to our General Assembly an intention to give equal dignity to proof of a conviction in another jurisdiction to that which properly inheres in those of our own state, when it may be that in many of these states important

39 Almendarez-Torres v. United States, 523 U.S. 224, 243 (1998); see also Graham v. West Virginia, 224 U.S. 616, 623 (1912) ("The propriety of inflicting severer punishment upon [recidivist] offenders has long been recognized in this country ....”).

${ }^{40}$ For more on the history of criminal recidivist laws, see Wayne A. Logan, Civil and Criminal Recidivists: Extraterritoriality in Tort and Crime, 73 U. CIN. L. REV. 1609, 1618-20 (2005) (tracing the history of U.S. recidivist laws back to the colonial era). In practical terms, the laws assumed importance only in the late 1700 s because until that time death was typically imposed on even first-time felons. Id. at 1618.

${ }^{41}$ The term "foreign" is used throughout this Article to refer to domestic jurisdictions other than the forum state (i.e., other U.S. states and the District of Columbia), not to other nations. For a discussion of the use of foreign nation convictions in making recidivist determinations, see Martha Kimes, Note, The Effect of Foreign Criminal Convictions Under American Repeat Offender Statutes: A Case Against the Use of Foreign Crimes in Determining Habitual Criminal Status, 35 COLUM. J. TRANSNAT'L L. 503, 506-18 (1997); Ethan A. Nadelmann, The Role of the United States in the International Enforcement of Criminal Law, 31 HARV. INT'L L.J. 37, 37 (1990) (noting that the challenge of confronting "transnational crime" has "internationalized" criminal law).

${ }^{42}$ See FRIEDMAN, supra note 32, at 22 (explaining that early American criminal justice was shaped by the fact that colonial life was "small-scale"). 
rules of procedure, in criminal trials, are entirely different from those which our Legislature has adopted for our government. ${ }^{43}$

In ensuing years, states became sensitized to the desirability of considering out-of-state convictions, despite the continued variability of state laws. By 1939, the recidivist laws of a majority of U.S. jurisdictions embraced the "external" method, which classified foreign convictions in the same way the foreign jurisdiction did at the time of conviction, regardless of how the offense would be regarded by the forum state. ${ }^{44}$ Under this method, the focus was on whether the foreign conviction resulted in sufficient punishment to warrant application of the forum's recidivist offender law (typically a one-year prison term, equating with felony status), not whether the underlying behavior was criminalized in the forum, or if a crime would warrant felony status (and thus enhancement viability) in the forum. ${ }^{45}$ Likewise, foreign convictions were recognized even if they were obtained without procedural or constitutional protections that would be available in the forum state. ${ }^{46}$ As the Idaho Supreme Court put it in 1942, the external approach embodies the sentiment that " $[\mathrm{g}]$ ood citizenship requires obedience and observance to the laws of sister states as much as those of this state." ${ }^{47}$

In 1961, the American Law Institute's Model Penal Code endorsed the external approach. ${ }^{48}$ According to the Code's commentary, deference to foreign state determinations "was regarded by the Institute as the most appropriate guide to the seriousness of the prior crime, a guide that also avoids the problems of grading crimes by forum law when the crimes are defined in a manner not replicated in the forum." ${ }^{49}$

On the other extreme there existed the "strict internal" view. With this approach the forum ignored foreign convictions, giving

${ }^{43}$ Lowe v. State, 177 S.E. 240, 240 (Ga. 1934).

${ }^{44}$ See Lyndon B. Allen, Comment, Provisions for Foreign Convictions in Habitual Criminal Legislation, 2 LA. L. REV. 177, 177 (1939) (defining the external view as according "foreign convictions ... exactly the same effect as local convictions").

${ }^{45} \mathrm{Id}$.

${ }^{46}$ See, e.g., People v. Johnson, 76 N.Y.S.2d 41, 42 (Gen. Term 1947) (recognizing two prior felony convictions in New Jersey even though the convictions were obtained after waiver of indictment, impermissible under New York law).

${ }^{47}$ State v. Prince, 132 P.2d 146, 149 (Idaho 1942).

48 See MODEL Penal CODE $\$ 7.05$ (1) (1962) ("[A foreign] conviction shall be deemed to have been of a felony if [a] sentence of death or of imprisonment in excess of one year was authorized under the law of [the] other jurisdiction ....").

Id. $\$ 7.05 \mathrm{cmt} .1$. 
them no effect whatsoever. ${ }^{50}$ By the mid-1970s only one state (Virginia) used such an approach. ${ }^{51}$

The remaining states compromised, adopting a modified internal approach, reflecting neither the extreme deference to the judgments of other states characteristic of the external view, nor the insular disregard for them marking the strict internal view. Under this approach, the forum court examined its indigenous law to determine whether the foreign conviction would qualify as a crime warranting recidivist enhancement under its own state law. ${ }^{52}$ Praising the approach in 1974, and presaging its state's adoption of the internal approach one year later, one New York court identified what it saw as the ill-effects of the external approach. Under it, an individual "convicted of Fornication in Alabama, Seduction in Texas, Blasphemy in New Jersey ... or of stealing a library book in North Carolina or a turkey in Arkansas," would be sentenced as a recidivist offender in New York, even though New York would not see fit to criminalize such behaviors, or would punish them by less than a year in prison, making them ineligible for enhancement. ${ }^{53}$

${ }^{50}$ Until recently, Florida's recidivist laws, in part, reflected such a strict internal view. For many years, the State's "habitual felon" law expressly excluded consideration of prior non-Florida felony convictions, while its "habitual violent felon" law did not. In 1989, the Florida Legislature amended the habitual felon law to allow consideration of foreign convictions. See Clark v. State, 823 So. 2d 809, 811-12 (Fla. Dist. Ct. App. 2002) (discussing the amendment expanding consideration of foreign convictions).

51 See Susan Buckley, Comment, Don't Steal a Turkey in Arkansas-The Second Felony Offender in New York, 45 FORDHAM L. REV. 76, 79 (1976) (citing and discussing VA. CODE ANN. §53-296 (1974), which "gives no effect to foreign convictions"); see also Note, Recidivism and Virginia's “Come-Back” Law, 48 VA. L. REV. 597, 597-601 (1962) (noting Virginia's refusal to consider foreign convictions and condemning the approach for its underinclusiveness).

${ }^{52}$ See Fletcher v. State, 409 A.2d 1254, 1255 (Del. 1979) (endorsing the limited internal approach, which eschews reliance "on technical classifications of other jurisdictions over which [the forum] legislature has no control").

${ }^{53}$ People v. Mazzie, 358 N.Y.S.2d 307, 311-12 (Sup. Ct. 1974) (citations omitted); see also Mitchell v. State, 467 A.2d 522, 533 (Md. Ct. Spec. App. 1983) ("Cutting cacti in California, uprooting the state flower ... in West Virginia, or desecrating a confederate cemetery in Mississippi may be felonies punishable by imprisonment in those states. We ... would not consider such acts as proper bases for mandatory sentencing-no matter how they are viewed by the several jurisdictions."). 


\section{Modern Approaches}

Today, a majority of jurisdictions (twenty-eight) employ a modified internal approach. ${ }^{54}$ As in the past, under this approach the sentencing court of the forum state examines the elements of the foreign conviction to determine if it would have qualified as a predicate for enhancement under the governing law of the forum. ${ }^{55}$ The states vary in the rigor of the statutory exegesis they require. New York, for in-

54 ALASKa STAT. § 12.55.145(a)(1)(B) (2004); ARIZ. REV. STAT. ANN. § 13-604(N) (2001); CAL. Penal CODE $\$ 667.5$ (f) (West 1999); CONN. GEN. STAT. ANN. § 53a-40 (West 2001); FlA. StAT. ANN. § 775.084(1)(c)(1)(r), .084(1)(e) (West 2005); GA. CODE ANN. § 17-10-7(a), (b) (2) (2004); 720 Ill. COMP. STAT. ANN. \$ 5/33B-1(a) (West 2003); LA. Rev. Stat. ANn. § 15:529.1(A) (1) (2005); ME. Rev. StAT. AnN. tit. 17-A, § 1252(4-A), (4-C) (1983 \& Supp. 2004); MiCH. COMP. LAWS ANN. \$§ 769.10(1), 769.11(1) (West 1998); MinN. STAT. ANN. § 609.1095(1)(d) (West 2003); N.Y. PENAL LAW $§ \S 70.04(1)(b)(i), 70.06(1)(b)(i)$ (McKinney 1998); N.C. GEN. STAT. § 15A1340.14(e) (2003); OHIO REV. CODE ANN. \$§ 2929.11, 2929.13(F)(6) (LexisNexis 2004); OKLA. STAT. ANN. tit. 21, § 54 (West 1983); OR. REv. STAT. $§ 161.725$ (2) (b), (c) (2003); 42 PA. CONS. STAT. ANN. §§ 9721, 303.8(f)(1), (2) (West 2004); S.C. CoDE ANN. $\S 17-25-45(\mathrm{~A})(2)$, (B) (3) (1976 \& Supp. 2004); S.D. CODIFIED LAwS $\S 22-7-7$ (2004 \& Supp. 2005); TENN. CODE ANN. \$§ 40-35-106(b) (5), -107(b) (5), -108(b) (5) (1997); UTAH CODE ANN. § 76-3-203.5(c)(ii) (2003); VT. STAT. ANN. tit. 13, §§ 11, 11a(a) (1998); VA. CODE ANN. § 19.2-297.1(B) (2004); WASH. REV. CODE ANN. §§ 9.92.090, 9.94A.030(29) (u), .030(33) (a) (ii), .030(40) (b), 9.94A.525(3) (West 2005).

In five states, the internal approach is used as a result of judicial interpretation. See Burgin v. State, 824 So. 2d 77, 81 (Ala. Crim. App. 2001) (interpreting ALA. CoDE $\$$ 13A-5-9(a)); Fletcher v. State, 409 A.2d 1254, 1255 (Del. 1979) (interpreting DEL. CodE ANN. tit. 11, § 4214); State v. Edmondson, 818 P.2d 855, 856-61 (N.M. Ct. App. 1991) (interpreting N.M. STAT. ANN. § 31-18-17(A)); Hubbard v. State, 544 A.2d 346, 352 (Md. Ct. Spec. App. 1988) (interpreting the predecessor to MD. CODE ANN., CRIM. LAW §14-101); Justice v. Hedrick, 350 S.E.2d 565, 566-69 (W. Va. 1986) (interpreting W. VA. CODE $§ 61-11-18)$.

${ }^{55}$ Typically, with both the internal and external approaches, the prosecution has the burden of convincing the court of the existence of an enhancement-eligible predicate by a preponderance of the evidence. See, e.g., State v. Cabrera, 868 P.2d 179, 181 (Wash. Ct. App. 1994) ("In establishing the defendant's criminal history for sentencing purposes, the State must prove by a preponderance of the evidence that a prior conviction exists."). But see State v. Mankiller, 722 P.2d 1183, 1192 (N.M. Ct. App. 1986) (holding that an out-of-state "judgment and sentence was prima facie proof of defendant's prior conviction" and that "[ $\mathrm{t}]$ he burden was then on defendant to show that the prior conviction did not qualify under the New Mexico habitual offender statute"). A few states require that eligibility be proven to the court beyond a reasonable doubt. See, e.g., IND. CODE ANN. § 35-50-2-8(g) (West 2004) (requiring proof beyond a reasonable doubt that the defendant accumulated two prior unrelated felony convictions). In addition, a handful of jurisdictions require that the jury, not the court, determine whether a prior conviction qualifies for enhancement. See infra note 187 (citing examples of jurisdictions requiring that the "fact" of prior conviction be proven before a jury). 
stance, uses a strict "essential elements" test, ${ }^{56}$ whereas other states require that foreign predicates have elements "similar" "57 or "substantially equivalent" "58 those warranting recidivist enhancement in the forum. With the internal approach courts must undertake a detailed comparative analysis of the respective criminal codes to ascertain whether the foreign conviction would warrant felony treatment in the forum..$^{59}$

The process can be difficult enough given the complex nature of modern criminal codes, with outcomes (even among physically contiguous states) ${ }^{60}$ turning on such questions as whether the states simi-

${ }^{56}$ See N.Y. PENAL LAW $\S 70.04$ (1) (b) (i) (McKinney 1998) ("The conviction must have been . . in any other jurisdiction of an offense which includes all of the essential elements of any such felony for which a sentence to a term of imprisonment in excess of one year ... is authorized in this state.").

${ }^{57}$ See, e.g., ALASKA STAT. \$ 12.55.145(a) (1) (B) (2004) (“[A] conviction in this or another jurisdiction of an offense having elements similar to those of a felony defined as such under Alaska law ... is considered a prior felony conviction ...."). In 1996, Alaska changed its criterion from "substantially identical" to "similar," a more inclusive standard. See Harlow v. State, 820 P.2d 307, 309 (Alaska Ct. App. 1991) ("The main difference between the two statutes, for purposes of this appeal, is that requiring a prior offense to have elements 'substantially identical' appears to be more strict than requiring the prior offense to have elements 'similar."').

58 See, e.g., OHIO REv. CODE ANN. § 2929.13(F) (6) (LexisNexis 2004) (incorporating any "offense under an existing or former law of this state, another state, or the United States that is or was substantially equivalent to one of those offenses"); see also CONN. GEN. STAT. ANN. \$ 53a-40 (West 2001) (requiring throughout that prior convictions in foreign states have "essential elements" that are "substantially the same"); FLA. STAT. ANN. § 775.084(1)(a)(1), .084(1)(e) (West 2005) (requiring that prior convictions in other states be "substantially similar in elements and penalties"); ME. REV. STAT. ANN. tit. 17-A, § 1252(4-A) (1983 \& Supp. 2004) (requiring convictions in other states to be for "essentially similar crimes").

${ }^{59}$ See, e.g., Ex parte French, 687 So. 2d 205, 206 (Ala. 1996) (rejecting the use of a Georgia felony conviction for sentence enhancement because the underlying conduct, possessing a firearm during a drug transaction, did not constitute a felony in Alabama); State v. Clough, 829 P.2d 1263, 1265-67 (Ariz. Ct. App. 1992) (rejecting the use of a prior Montana felony conviction for issuing a bad check because analogous crime in Arizona contained an intent element lacking in Montana law); State v. Glenn, 493 So. 2d 806, 813-14 (La. Ct. App. 1986) (rejecting the use of a Texas felony conviction for unauthorized use of a motor vehicle because the equivalent behavior constituted a misdemeanor in Louisiana); People v. Gonzalez, 463 N.E.2d 1210, 1211 (N.Y. 1984) (rejecting the use of two Florida convictions for aggravated assault because it was unclear whether or not the underlying conduct constituted a felony in New York).

${ }^{60}$ See, e.g., Robinson v. State, 692 So. 2d 883, 888 (Fla. 1997) (rejecting the use of a Georgia conviction for "robbery by sudden snatching" because its elements were not "substantially similar" to those of the comparable Florida offense); Lewis v. State, 587 S.E.2d 245, 246-47 (Ga. Ct. App. 2003) (rejecting the use of a Tennessee conviction for aggravated assault because the defendant's "conduct may not constitute a felony in Georgia"). 
larly define burglary, ${ }^{61}$ assault, ${ }^{62}$ or driving under the influence and causing bodily harm; ${ }^{63}$ employ similar monetary loss thresholds for larceny convictions $;{ }^{64}$ or use similar levels of impairment for purposes of defining driving under the influence. ${ }^{65}$ Often the interpretative task is made more difficult by the lack of a precisely analogous criminal provision in the foreign state. In Tennessee, for instance, statutory law provides that when a foreign felony "is not a named felony in this state, the elements of the offense shall be used by the Tennessee court to determine what classification the offense is given." ${ }^{\prime 6}$ Moreover, the task is complicated by the requirement that courts must identify and construe the foreign criminal law in effect when the predicate conviction was rendered, which frequently entails historical review dating back many years. ${ }^{67}$

While some jurisdictions prohibit consultation of the record supporting the foreign conviction, focusing only on the elements of the offense committed, ${ }^{68}$ many do allow the evidentiary record to be consulted, permitting consideration of accusatory instruments, plea tran-

${ }^{61}$ See, e.g., Timothy v. State, 90 P.3d 177, 180 (Alaska Ct. App. 2004) (holding that Alaska's definition of "burglary" differed sufficiently from Illinois' that defendant's Illinois burglary conviction could not justify an enhanced sentence).

${ }^{62}$ See, e.g., State v. Tapp, 821 P.2d 1098, 1099-1100 (Or. Ct. App. 1991) (determining that the elements of assault in Washington State would not constitute a felony in Oregon).

63 See Leocal v. Ashcroft, 125 S. Ct. 377, 381-82 \& nn.5-6 (2004) (noting the varied mens rea requirements among state drunk driving laws).

${ }^{64}$ See, e.g., State v. Acosta, No. 29512-1-II, 2004 Wash. App. LEXIS 2187, at *29 (Ct. App. Sept. 21, 2004) (distinguishing the value element of Washington's second degree theft laws from California's petty theft law, which lacks a value determination).

${ }^{65}$ See, e.g., Commonwealth v. Shaw, 744 A.2d 739, 744-45 (Pa. 2000) (holding that New York's provision "requires an appreciably lesser degree of impairment than does Pennsylvania's”); $c f$. Shinault v. Commonwealth, 321 S.E.2d 652, 654 (Va. 1984) (holding that Virginia and North Carolina laws are not "substantially similar" due to the differing effects of presumptions in their respective laws).

${ }_{66}$ Tenn. Code AnN. \$ 40-35-106(b) (5) (1997); see also People v. Quintanilla, 571 N.W.2d 228, 228 (Mich. Ct. App. 1997) (holding that the conduct proscribed by foreign law, not its classification as a felony in the foreign state, controls analysis of whether felony recidivist status is warranted in Michigan).

${ }^{67}$ Mississippi, for instance, imposes no time limit on the remoteness of prior convictions. See Adams v. State, 410 So. 2d 1332, 1334 (Miss. 1982) ("Remoteness in the convictions relied upon for enhanced punishment is not a factor to be considered.").

${ }^{68}$ See, e.g., Montoure v. State, 880 So. 2d 793, 794 (Fla. Dist. Ct. App. 2004) (holding that Florida courts can only consider the elements of a foreign conviction, and not the trial record, when determining whether an out-of-state crime has a Florida equivalent); State v. Golden, 829 P.2d 88, 90 (Or. Ct. App. 1992) (noting that Oregon courts can consider only the elements of the foreign conviction, not its underlying facts, in determining the criminal history of the individual to be sentenced). 
scripts, and the like. ${ }^{69}$ This evaluative task itself can be quite difficult because the records supporting pleas or convictions (themselves often aged) are frequently ambiguous or incomplete. ${ }^{70}$ As New York's highest court put it, "[d] etermining whether a particular out-of-State conviction is the equivalent of a New York felony may involve production and examination of foreign accusatory instruments and, conceivably, the resolution of evidentiary disputes, all in the context of comparisons with the law of other jurisdictions." ${ }^{71}$ Adding to the uncertainty, judicial analysis can be influenced by the public policy informing the forum's recidivist law and perhaps the predicate crime itself. ${ }^{72}$

Most jurisdictions using the internal approach do not attach dispositive significance to the punishment imposed by the foreign state; rather, their analysis turns on whether the foreign crime of conviction would be punishable as a felony in the forum. ${ }^{73}$ In State $v$. Bush, for

${ }^{69}$ California permits this as a matter of course. See People v. Riel, 998 P.2d 969, 1005 (Cal. 2000) (holding that the government can "go behind the statutory elements of the crime to prove that a defendant's actual crime constitutes a felony under California law"). Other jurisdictions do so only under limited circumstances. See, e.g., State v. Miller, No. 29326-9-II, 2004 WL 1240374, at *3 (Wash. Ct. App. May 25, 2004) ("If the elements are not identical or if the Washington statute defines the offense more narrowly than does the foreign statute, the trial court may review the record of the out-of-state conviction to determine whether the defendant's conduct would have violated the comparable Washington offense.").

${ }^{70}$ See, e.g., Lewis v. State, 587 S.E.2d 245, 246-47 (Ga. Ct. App. 2003) (rejecting the use of a Tennessee conviction for sentence enhancement because the record did not make clear whether the conduct underlying the offense to which the defendant pled guilty would constitute a felony in Georgia).

${ }^{71}$ People v. Samms, 731 N.E.2d 1118, 1122 (N.Y. 2000). Some fifty years before, the same court warned of the perils of relying on accusatory instruments:

The application of [recidivist enhancement] cannot be made to turn upon the expansiveness of the prosecutor who prepared and drafted the indictment in the other State. One prosecutor may content himself with pleading only essential allegations, while another may choose to include immaterial and surplus recitals. Liberty-even of habitual malefactors-is too important to depend upon the drafting technique or the pleading preference of a particular official.

People v. Olah, 89 N.E.2d 329, 332 (N.Y. 1949).

${ }^{72}$ See, e.g., State v. Zulfer, 547 S.E.2d 885, 887-88 (S.C. Ct. App. 2001) ("To shift the focus to the fact that a defendant's prior offenses may have occurred in different jurisdictions would thwart the objective of requiring heightened accountability from repeat offenders for their subsequent crimes."). But see Commonwealth v. Shaw, 744 A.2d 739, 745 (Pa. 2000) (Cappy, J., concurring) (criticizing the majority for continuing "to promote the fiction that equivalency can also be determined by the mere fact that the underlying public policy of both statutes is similar").

${ }^{73}$ As noted by the Louisiana Court of Appeal, " $[\mathrm{t}]$ he habitual offender statute requires Louisiana courts to determine the analogous Louisiana crime according to the nature of the act involved in the crime of the other state or jurisdiction, not the pen- 
instance, the Washington Supreme Court deemed a Kansas misdemeanor battery conviction a felony for enhancement purposes because the conduct at issue was categorized as a felony under Washington law. ${ }^{74}$ According to the Bush court, this was "to ensure that defendants with equivalent prior convictions are treated the same way regardless of whether those prior convictions were incurred in Washington or elsewhere." ${ }^{75}$ Disregarding the foreign punishment outcome avoided allowing a repeat offender to evade "imposition of a greater sentence merely because the other state imposes a shorter prison term." ${ }^{76}$ Washington courts, in short, enjoy full authority to "reclassify the conviction of a sister state to determine punishment for a current in-state conviction. This reclassification process has no impact on the full faith and credit clause because a sister state has no authority to regulate Washington's sentencing process." ${ }^{77}$

In some internal approach states, however, the focus is on the length of punishment imposed by the foreign sovereign, but again without regard for how the offense is classified (felony or misdemeanor) there. In Ware v. Commonwealth, for instance, the defendant pled guilty to a felony (stalking) in Kentucky, and the prosecution successfully petitioned to have him qualify as a persistent felony offender based on two prior North Carolina convictions for driving with a revoked license and causing damage to personal property. ${ }^{78}$ While North Carolina designated both prior convictions as misdemeanors, each carried a maximum penalty of up to two years imprisonment, and Ware received sentences of eighteen months (probated for three

alty provided for the offense in the other state or jurisdiction." State v. Hennis, 734 So. 2d 21, 24 (La. Ct. App. 1999); see also, e.g., Dunham v. State, 762 P.2d 969, 975 (Okla. Crim. App. 1988) (ordering a reduction in the defendant's sentence because "the length of the sentence imposed under Missouri law is not a proper basis for determining whether a crime is a misdemeanor or a felony under Oklahoma law"); Justice v. Hedrick, 350 S.E.2d 565, 568 (W. Va. 1986) ("[W] hether the conviction of a crime outside of West Virginia may be the basis for application of the West Virginia Habitual Criminal Statute depends upon the classification of that crime in this State." (citation omitted)).

${ }^{74} 9$ P.3d 219, 223-24 (Wash. Ct. App. 2000).

${ }^{75} I d$. at 225 .

${ }^{76}$ Id. (internal quotation marks omitted) (quoting State v. Franklin, 729 P.2d 70, 73 (Wash. Ct. App. 1986)); see also id. ("The elements of the crime, not its maximum punishment, determine whether a crime is comparable.").

${ }^{77}$ Id. For a similar expression of this sentiment see, for example, Mancini v. State, 904 P.2d 430, 432-33 (Alaska Ct. App. 1995) ("The effect of a prior criminal conviction ... on the sentencing of an Alaska offender implicates issues of policy that are uniquely Alaskan in character and have nothing to do with California law.").

7847 S.W.3d 333, 333-34 (Ky. 2001). 
years) for the driving conviction and two years (probated for three years) for the damage to property conviction. ${ }^{79}$ Because Kentucky law deemed a felony any conviction for which a sentence of more than one year was imposed, regardless of its classification in the foreign state, the North Carolina misdemeanor convictions were properly counted in Kentucky, ${ }^{80}$ even though North Carolina would not have treated Ware as a felon recidivist. ${ }^{81}$

This punishment-specific focus can lead to some uncertain outcomes. While it is often the case, as in Ware, that the analysis does not redound to a defendant's benefit, the opposite can be true. Such an outcome occurs when a foreign state classifies the conduct underlying the conviction as a felony yet the forum state does not, requiring that the prior conviction be disregarded for enhancement purposes. ${ }^{82}$

The skepticism characteristic of the internal approach also extends to various types of dispositions. For instance, foreign convictions resulting in dismissal because the defendant satisfied terms of probation or deferred adjudication can be counted by the forum, even when the foreign jurisdiction would ignore such convictions for enhancement purposes. ${ }^{83}$ Similarly, foreign pleas of nolo contendere

${ }^{79}$ Id. at 334.

${ }^{80} I d$. In support, the Ware court cited to the law's 1974 commentary suggesting that the standard

seeks to account for the possibility of conviction from a state which has a distinction between felony and misdemeanor that is different from that used in this state. Thus, although such conviction is for an offense designated in that other state as a misdemeanor, it can be treated as a felony for purposes of this statute if it carried a penalty of one year or more.

Id. (quoting KY. REV. STAT. ANN. § 532.080 cmt. (1974)).

${ }^{81}$ See N.C. GEN. STAT. ANN. \$ 15A-1340.14(b) (1)-(5) (2003) (noting that in North Carolina, non-traffic misdemeanor convictions add one point to an offender's prior record score, while felonies add between two and ten points).

${ }^{82}$ See, e.g., Elston v. State, 687 So. 2d 1239, 1241 (Ala. Crim. App. 1996) ("When the state seeks to use a defendant's out-of-state felony convictions to enhance his sentence under [Alabama law], the state must prove that the conduct for which the defendant was previously convicted constituted a felony in Alabama when it was committed.").

See, e.g., People v. Laino, 87 P.3d 27, 37-39 (Cal. 2004) (ruling that a defendant's earlier conviction for aggravated assault in Arizona, for which he was placed in a diversion program, was a conviction under California's three strikes law); State v. Courtney, 682 N.W.2d 185, 201 (Minn. Ct. App. 2004) (holding that crimes for which the defendant had received a suspended imposition of sentence in another state could be used to enhance a subsequent Minnesota sentence), rev'd on other grounds, 696 N.W.2d 73 (Minn. 2005); State v. Edmondson, 818 P.2d 855, 857 (N.M. Ct. App. 1991) (sustaining the enhanced sentence of a defendant who had received deferred adjudication in Texas because even though his conviction could not be considered in Texas, "[i]t does 
can be counted when the foreign states themselves would not count nolo pleas when assessing recidivism, ${ }^{84}$ or, if counted by the foreign state, can be disregarded when the forum state deems them unworthy of recidivism consideration. ${ }^{85}$ Finally, internal states typically disregard foreign decisions to expunge convictions, ${ }^{86}$ and disregard foreign decisions to restore the civil rights of convicted felons (e.g., the right to carry a firearm). ${ }^{87}$ In short, as the California Supreme Court recently noted, jurisdictions adopting the internal approach take the view that "the profile of the shadow that conviction casts on later events is the business of the state where those later events occur." " 88

Internal approach states show considerable variation in their treatment of foreign decisions relative to the treatment of juvenile offenders. Very often prior juvenile misconduct is not counted when the forum would ignore it for recidivist purposes, even if it would justify enhancement in the foreign jurisdiction. In State $v$. Thomas, ${ }^{89}$ for instance, the Minnesota Court of Appeals refused to count a foreign juvenile conviction, citing its concern that "defendants with similar criminal histories should not receive disparate treatment depending on the age of majority of the state in which they committed prior of-

not follow, however, that a New Mexico court cannot use the conviction for purposes of our habitual-offender statute").

${ }^{84}$ See, e.g., McClish v. State, 962 S.W.2d 332, 335 (Ark. 1998) (upholding the trial court's decision to consider evidence of the defendant's foreign nolo pleas and deferred sentence when determining whether the defendant was a habitual offender).

${ }^{85}$ See, e.g., McCray v. State, 738 So. 2d 911, 916 (Ala. Crim. App. 1998) (holding that a defendant's prior Florida convictions based on nolo pleas could not be used in Alabama to enhance his punishment).

${ }^{86}$ See State v. Clifton, 481 S.E.2d 393, 399-400 (N.C. Ct. App. 1997) (surveying state treatments of expunctions). Executive pardons, on the other hand, do often receive deference, with states taking one of two approaches: regarding pardons as "removing an adjudication of guilt" or regarding pardons as having the "effect of removing punishment and penalties and restoring civil rights, but [failing to] remove the adjudication of guilt." R.J.L. v. State, 887 So. 2d 1268, 1278-79 (Fla. 2004). States have also enacted provisions specifying that pardons based on innocence be accorded special deference. See, e.g., N.Y. PENAL LAW $§ 70.06$ (1) (b) (vi) (McKinney 1998) (barring consideration of felony convictions when defendant has been pardoned on innocence grounds).

${ }^{87}$ See, e.g., Farnsworth v. Commonwealth, 599 S.E.2d 482, 487 (Va. Ct. App. 2004) (ignoring West Virginia's decision to restore a defendant's right to carry a firearm and permitting a defendant to be prosecuted for illegal firearm possession in Virginia), aff'd, 599 S.E.2d 482 (Va. 2005).

${ }^{88}$ Laino, 87 P.3d at 37 (quoting Poo v. Head, 1992 WL 30617, at *6 (S.D.N.Y. Feb. $12,1992)$ ); see also id. at 40 ("No matter what leniency Arizona may or may not bestow upon its recidivist criminals ... once we are satisfied that such conviction constitutes a strike under our three strikes law, that prior crime will count here.").

89374 N.W.2d 586 (Minn. Ct. App. 1985). 
fenses." ${ }^{90}$ Not all states evince such a critical view, however. For instance, in Louisiana, a youth accorded adult status by a foreign court and convicted of a felony there will be deemed a recidivist even though Louisiana would have processed the youth as a juvenile and later would have withheld recidivist enhancement. ${ }^{91}$

Alternatively, twenty-two jurisdictions (including the District of Columbia) today use an external approach when assessing foreign convictions. $^{92}$ As with the earlier incarnation of the approach, disposi-

${ }^{90}$ Id. at 588; see also, e.g., Justice v. Hedrick, 350 S.E.2d 565, 568 (W. Va. 1986) (rejecting consideration of a prior Michigan conviction because the defendant would have been treated as a juvenile in West Virginia).

${ }^{91}$ See State v. Youngblood, 647 So. 2d 1388, 1391-92 (La. Ct. App. 1994) (upholding sentencing enhancement based on a foreign conviction while the defendant was a juvenile). According to the court, by treating the juvenile as an adult, the "youthful offender is made aware of the seriousness of his behavior and thereby placed on notice that, in the event of further violations, society will not regard his actions as minor childhood transgressions to be forgiven upon reaching maturity." Id. at 1391; see also McManners v. State, 650 P.2d 414, 416 (Alaska Ct. App. 1982) (counting a foreign juvenile conviction and noting that "'recent criminal conduct, regardless of whether it antedates the somewhat fortuitous date of legal majority, can aid in the effort to ascertain the magnitude of a defendant's threat to society'" (quoting Davenport v. State, 543 P.2d 1204, 1211 (Alaska 1975)).

${ }^{92}$ ARK. CODE ANN. § 5-4-503 (1997); COLO. REV. STAT. § 18-1.3-801(2) (2004); D.C. CODE ANN. § 22-1804a(b) (1) (LexisNexis 2001 \& Supp. 2005); HAW. REV. STAT. § 706-665 (1993); IDAHO CODE ANN. § 19-2514 (2004); IND. CODE ANN. § 35-50-2-1(a) (b) (West 2004); IOWA CODE ANN. \$902.8 (West 2003); KAN. STAT. ANN. \$§ 21-4504, 214711 (e) (2004); Ky. REV. STAT. ANN. § 532.080 (LexisNexis 1999); MASS. ANN. LAWS ch. 279, § 25 (LexisNexis 2002); MISS. CODE ANN. §§ 99-19-81, 99-19-83 (West 1999); Mont. Code AnN. § 46-18-501 (2003); Neb. Rev. Stat. § 29-2221 (1995); Nev. Rev. STAT. ANN. § 207.010(1) (a) (LexisNexis 2001); N.H. REV. STAT. ANN. § 651:6(II) (LexisNexis Supp. 2004); N.J. STAT. ANN. § 2C:44-4(c) (West 2005); R.I. GEN. LAWS § 12-1921 (2002); Wis. STAT. ANN. § 939.62(2), (3) (b) (West 2005); Wyo. STAT. ANN. § 6-10201 (2005). North Dakota also employs the external approach, but counts foreign convictions only when they are punishable by a maximum term of five years or more. N.D. CENT. CODE § 12.1-32-09(1) (c) (1997 \& Supp. 2005).

Missouri and Texas have adopted the external approach as a result of judicial decision. See State v. Taylor, 779 S.W.2d 636, 642 (Mo. Ct. App. 1989) ("The State was not required to prove that the conduct underlying defendant's Kansas felony conviction would have been punishable as a felony under Missouri law."); Dotson v. State, 28 S.W.3d 53, 57 (Tex. Ct. App. 2000) (deferring to Louisiana's classification of the offense as a felony and using a prior Louisiana conviction for enhancement).

State laws, it is important to note, can vary in their fealty to methods of recidivist assessment, depending on the circumstances. For instance, North Carolina, which uses an internal approach for purposes of assessing criminal history, see supra note 54, uses an external approach when evaluating foreign misconduct for purposes of evaluating "habitual felons." See N.C. GEN. STAT. ANN. § 14-7.1 (2003) (defining a predicate offense as "an offense which is a felony under the laws of the State or other sovereign wherein a plea of guilty was entered or a conviction was returned regardless of the sentence actually imposed"). On the other hand, New Jersey's "three strikes" law, unlike 
tive importance attaches to how the foreign jurisdiction treated the earlier conviction. If the previous misconduct resulted in a felony conviction in another jurisdiction, the forum state will consider it for enhancement, even if the offense would not have been a felony in the forum state and thus would not trigger enhancement if committed there. $^{93}$ As noted by the Idaho Court of Appeals, foreign predicates "must be for felonies under the laws of the state where the conviction was entered.... [I]t [is] immaterial... whether the convictions in other states were for crimes that would also have been felonies under Idaho law, so long as they were for felonies where the offenses occurred." In New Jersey, however, foreign misdemeanors for which punishment in excess of six months is "authorized" (not necessarily

its general recidivist enhancement law that uses the external approach, requires that a foreign conviction be based on a "similar" statute to that warranting a strike in New Jersey or a crime that is "substantially equivalent" to an enumerated crime. See N.J. STAT. ANN. § 2C:43-7.1 (West 2005). Likewise, Wisconsin's "three strikes" law is triggered by foreign predicates that are "comparable" to offenses qualifying under its law. See WIS. STAT. ANN. § 939.62(2m)(d) (defining "[s] erious felony" as a crime under the "law of any other state ... that is comparable" to an enumerated Wisconsin predicate). Texas, for its part, employs the internal approach for its life-eligible enhancements. See Tex. Penal Code ANn. § 12.42(c)(2)(B) (v), .42(g)(2) (Vernon 2003 \& Supp. 2005) (counting foreign convictions for offenses having "elements that are substantially similar").

Recidivist laws can also single out specific predicate crimes for internal approach treatment. Colorado's external approach law, for instance, manifests its concern for differing state views on drug offenses in particular, creating an exception for foreign drug-related convictions. See Colo. Rev. STAT. ANN. § 18-1.3-801(1) (f) (3) (West 2004) ("No drug law conviction shall be counted as a prior felony conviction ... unless such prior offense would be a felony if committed in this state at the time of the commission of the new offense.”); $c f$. N.C. GEN. STAT. ANN. § 14-7.1 (2003) (specifically prohibiting consideration of prior federal felony convictions for alcohol-related offenses).

${ }^{93}$ See, e.g., People v. Johnson, 74 P.3d 349, 356 (Colo. Ct. App. 2002) (allowing enhancement for a prior California felony of "petty theft with a prior conviction"); State v. Crispin, 671 P.2d 502, 509 (Kan. 1983) (allowing enhancement for a prior California felony DUI); State v. Rellihan, 662 S.W.2d 535, 539 (Mo. Ct. App. 1983) (allowing enhancement for a prior Oklahoma felony of "burglary of a vending machine"); Dotson v. State, 28 S.W.3d 53, 56-57 (Tex. App. 2000) (allowing enhancement for a prior Louisiana felony conviction for "illegal possession of stolen things," which required a lower dollar amount than required by Texas law); Cain v. State, 721 S.W.2d 493, 494-95 (Tex. App. 1986) (allowing enhancement for a prior Louisiana felony conviction for negligent homicide).

${ }^{94}$ State v. Williams, 651 P.2d 569, 580 (Idaho Ct. App. 1982); see also, e.g., Gunderson v. State, 925 P.2d 1300, 1305 (Wyo. 1996) ("The fact that the previous convictions were felonies in the rendering states but may not have been felonies in Wyoming is immaterial. The convictions were still felony convictions."). 
imposed) are eligible for enhancement. ${ }^{95}$ As a result, an offender who receives a fine as a sentence, and hence was afforded neither a right to counsel $^{96}$ nor indictment, ${ }^{97}$ can be subject to enhancement. ${ }^{98}$

External approach states also show greater tolerance for different procedures used in their fellow states. This deference often translates into a disregard of the procedural norms that would otherwise preclude consideration of such convictions if they had occurred in-state. For instance, if a foreign state counts a juvenile conviction it will be counted in the forum state, irrespective of the latter's refusal to consider juvenile misconduct for its indigenous offenders. ${ }^{99}$ Likewise, nolo contendere pleas, if counted by the foreign state, are counted in the forum state even when not recognized under its enhancement law. ${ }^{100}$ In addition, foreign predicates rising to felony status only because they themselves were enhanced can be counted for purposes of sentence enhancement. ${ }^{101}$

${ }^{95}$ See N.J. STAT. ANN. $\$$ 2C:44-3, :44-4 (West 2005) (including a conviction in another jurisdiction with over six months of imprisonment as a "prior conviction" for which enhancement is authorized).

${ }^{96}$ See Scott v. Illinois, 440 U.S. 367, 373 (1979) (holding that the Sixth Amendment right to appointed counsel is triggered only when the defendant is subject to "actual imprisonment"). While for a time uncounseled convictions could not be used to enhance sentences for subsequent convictions, see Baldasar v. Illinois, 446 U.S. 222, 227 (1980) (holding that an uncounseled misdemeanor conviction could not be used to support an enhancement for a second misdemeanor theft conviction), the Supreme Court eventually lifted this prohibition, see Nichols v. United States, 511 U.S. 738, 746 (1994) (allowing a sentencing court to consider a prior uncounseled misdemeanor for a sentence enhancement when the misdemeanor did not result in imprisonment).

${ }^{97}$ See 2 SARA Sun BeAle ET AL., GRAND JURY LAW AND PRACTICE $\$ 8.2$ (2d ed. 2004) (surveying different state provisions on when the right to indictment attaches).

${ }^{98}$ Such outcomes provide a prime example of a subtle yet important effect: substantive laws undercutting procedural protections. For more on this phenomenon, see Darryl K. Brown, The Warren Court, Criminal Procedure Reform, and Retributive Punishment, 59 WASH. \& LEE. L. REV. 1411, 1413 (2002) (discussing the power of the legislative and executive branches to use substantive law to neutralize criminal procedure protections).

${ }^{99}$ See, e.g., State v. Taylor, 781 S.W.2d 229, 232 (Mo. Ct. App. 1989) (finding the defendant a persistent offender because his prior conduct was a felony in Arkansas, even though he would have been adjudicated as a juvenile in Missouri).

${ }^{100}$ See, e.g., State v. Vizcaino-Roque, 800 S.W.2d 22, 23 (Mo. Ct. App. 1990) (allowing sentence enhancement based on a nolo contendere plea in Florida).

${ }^{101}$ See, e.g., People v. Johnson, 74 P.3d 349, 356 (Colo. Ct. App. 2003) (allowing enhancement in Colorado based on a prior California felony of "petty theft with a prior conviction"). 


\section{B. Sex Offender Registration}

\section{Background}

Requiring criminal offenders to register with government authorities first took root in the United States in the 1930s. The initial registration provisions were enacted by municipalities and typically targeted felons as a class. ${ }^{102}$ While nominally intended to help police monitor and track ex-offenders in the jurisdiction, the ordinances in fact were often used to discourage ex-offenders from locating to cities in the first instance, and failing this, as a ready basis for incarceration and expulsion (via bartered suspended sentences) should the exoffender violate the registration requirement. ${ }^{103}$ To maximize coverage, the municipal ordinances took account of foreign convictions, using internal and external approaches. ${ }^{104}$ The Norfolk, Virginia, ordinance for instance broadly provided that "“[a]ny person who ... has been ... convicted of any offense punishable as a felony in the state or elsewhere" must register, seemingly requiring a familiarity with the laws of jurisdictions worldwide. ${ }^{105}$ By 1957, the era of municipal registration laws came to an end as the U.S. Supreme Court invalidated a Los Angeles ordinance on due process grounds out of concern that reasonable persons were not likely to recognize the need to inquire into the existence of the local law. ${ }^{106}$

In the 1990s, registration was resuscitated, this time by state governments that singled out sex offenders in particular. Triggered by high-profile victimizations of eleven-year-old Jacob Wetterling in Minnesota and seven-year-old Megan Kanka in New Jersey, states nationwide enacted registration laws, augmented eventually with requirements that community members be notified of registrants' presence

${ }^{102}$ See Note, Criminal Registration Ordinances: Police Control Over Potential Recidivists, 103 U. PA. L. REV. 60, 61-63 (1954) (discussing the history and background of registration provisions). As of 1954, only five states (Arizona, California, Florida, Illinois, and New Jersey) had criminal registration statutes. Id. at 65 n.28.

${ }^{103} I d$. at $63,104$.

${ }^{104} I d$. at 68-69.

${ }^{105} I d$. at 69 n.50 (quoting the registration ordinance of Norfolk, Virginia).

${ }^{106}$ See Lambert v. California, 355 U.S. 225, 228-29 (1957) (holding that due process requires "actual knowledge of the duty to register or proof of the probability of such knowledge"). The Court was also troubled by the passive nature of the prohibition (i.e., punishing an omission, not an act) and that the offense itself was malum prohibitum. Id. For further discussion of Lambert and its influence on modern registration laws enacted by states, see infra notes 217-24 and accompanying text. 
(community notification). ${ }^{107}$ Today, all U.S. jurisdictions have registration laws in effect, prompted by the federal government's threats in the Jacob Wetterling Act (1994) ${ }^{108}$ and Megan's Law (1996) ${ }^{109}$ to withhold funds from non-compliant states. ${ }^{110}$ The laws specify that states must register persons convicted of criminal offenses against victims who are minors, ${ }^{111}$ as well as those convicted of a "sexually violent offense," 112 and maintain registration of such individuals for a minimum

${ }^{107}$ See Wayne A. Logan, Sex Offender Registration and Community Notification: Emerging Legal and Research Issues, 989 ANNALS N.Y. ACAD. SCI. 337, 337-38 (2003) (recounting events leading to the modern proliferation of registration and notification laws).

${ }^{108}$ Jacob Wetterling Crimes Against Children and Sexually Violent Offenders Registration Act, Pub. L. No. 103-322, § 170101, 108 Stat. 1796, 2038 (1994) (codified as amended at 42 U.S.C. $\$ 14071$ (2000)).

${ }^{109}$ Megan's Law, Pub. L. No. 104-145, 110 Stat. 1345 (1996) (amending 42 U.S.C. $\S 14071(\mathrm{~d})(1996))$.

${ }^{110}$ See 42 U.S.C. $\$ 14071(\mathrm{~g})(2)(\mathrm{A})$, (B) (2000) (specifying that non-compliant states shall not receive ten percent of federal funds otherwise allotted and that such money is to be reallocated among compliant states). For criticism of Congress' budgetary strong-arm techniques in this area and others, see Richard W. Garnett, The New Federalism, The Spending Power, and Federal Criminal Law, 89 CORNELl L. REv. 1, 23 (2003). The irony of conservative federal legislators holding states fiscally hostage to federal policy desires, while at the same time touting states' rights, was not lost on at least one elected representative. See 142 CONG. REC. H4456 (daily ed. May 7, 1996) (statement of Rep. Melvin Watt) (criticizing "Big Brother Government" and urging that states be able "to make their own decisions about whether they want a Megan's law or do not want a Megan's law").

${ }^{111}$ The category is defined as the following:

[A]ny criminal offense in a range of offenses specified by State law which is comparable to or which exceeds the following range of offenses:

(i) kidnapping of a minor, except by a parent;

(ii) false imprisonment of a minor, except by a parent;

(iii) criminal sexual conduct toward a minor;

(iv) solicitation of a minor to engage in sexual conduct;

(v) use of a minor in a sexual performance;

(vi) solicitation of a minor to practice prostitution;

(vii) any conduct that by its nature is a sexual offense against a minor; or

(viii) an attempt to commit an offense described in any of the clauses (i) through (vii), if the State-

(I) makes such an attempt a criminal offense; and

(II) chooses to include such an offense in those which are criminal offenses

against a victim who is a minor for the purposes of this section.

42 U.S.C. $\$ 14071(\mathrm{a})(3)(\mathrm{A})$.

${ }^{112}$ See id. $\S 14071$ (a) (3) (B) (including "a range of [state law] offenses ... which is comparable to or which exceeds the range of offenses encompassed by aggravated sexual abuse or sexual abuse ... [or] that has as its elements engaging in physical contact with another person with intent to commit aggravated sexual abuse or sexual abuse"). 
of ten years. ${ }^{113}$ The Pam Lyncher Act (1996), ${ }^{114}$ named after an adult sexual assault victim, requires lifetime registration for offenders with two or more prior convictions for registration-eligible offenses and those initially convicted of specified "aggravated" sex offenses. ${ }^{115}$ Finally, in 1998, Congress required that states take steps to identify "sexually violent predators," by means of judicial hearings. ${ }^{116}$ Such offenders, who are subject to lifetime registration and must verify their address information with the state on a quarterly basis, ${ }^{117}$ are those who have "been convicted of a sexually violent offense and who suffer[] from a mental abnormality or personality disorder that makes [them] likely to engage in predatory sexually violent offenses."118

Current state laws at a minimum contain the aforementioned registration eligibility criteria. However, as the implementing guidelines make clear, these standards "constitute a floor for state programs, not a ceiling." 119 States are free to broaden the list of offenses warranting registration, lengthen the mandated minimum periods of registration, and impose more stringent registration regulations than federal law. ${ }^{120}$ As a result, significant variation exists in the types of offenses warranting registration under state laws.

For instance, Alabama targets public display of obscene bumper stickers, signs, or writings; ${ }^{121}$ Kansas, adultery if one party is less than

${ }^{113} I d . \S 14071$ (b) (6) (A); see also Megan's Law; Final Guidelines for the Jacob Wetterling Crimes Against Children and Sexually Violent Offender Registration Act, 64 Fed. Reg. 572, 579 (Jan. 5, 1999) (describing the minimum registration procedures required of states).

${ }^{114}$ Pam Lyncher Sexual Offender Tracking and Identification Act of 1996, Pub. L. No. 104-236, 110 Stat. 3093 (codified as amended at 42 U.S.C. $\$ 14072$ (2000)).

${ }^{115} 42$ U.S.C. $\$ 14072(d)(2)$.

${ }^{116}$ Id. $\S 14071(\mathrm{a})(2)$, (a) (3), (b) (1)(B), (b) (6) (B); see also Final Guidelines, 64 Fed. Reg. at 583 (describing special registration process for "sexually violent predators").

11742 U.S.C. $\$ 14071$ (b) (3) (B).

${ }^{118} I d$. $\S 14071$ (a) (3)(C). For a definition of "sexually violent offense," see supra note 112. Federal law defines "mental abnormality" as "a congenital or acquired condition of the person that affects the emotional or volitional capacity of the person in a manner that predisposes that person to the commission of criminal sexual acts to a degree that makes the person a menace to the health and safety of other persons." 42 U.S.C. § 14071(a)(3)(D) (2000). Congress failed to define "personality disorder," making it a matter of state discretion. See Final Guidelines, 64 Fed. Reg. at 583 ("The definition of 'personality disorder' is a matter of state discretion since the Act includes no specification on this point.").

${ }^{119}$ Final Guidelines, 64 Fed. Reg. at 575.

${ }^{120} I d$.

${ }^{121}$ ALA. CODE $§ 13 A-11-200$ (Supp. 2005). 
eighteen years of age; ${ }^{122}$ Oregon, promoting (and compelling) prostitution, ${ }^{123}$ South Dakota, bestiality and indecent exposure; ${ }^{124}$ South Carolina, peeping, voyeurism, buggery, indecent exposure, or a "similar offense"; ${ }^{125}$ Idaho and Louisiana, a "crime against nature"; ${ }^{126}$ North Dakota, peeping and indecent exposure; ${ }^{127}$ and Connecticut, consensual sex between minors. ${ }^{128}$ Moreover, several states target the possession of child pornography (as opposed to its production or distribution) $;{ }^{129}$ require registration for non-sexual offense convictions that do not involve child victims-e.g., involuntary manslaughter (Kansas), ${ }^{130}$ kidnapping (Minnesota), ${ }^{131}$ or homicide and aggravated assault (Montana) $;^{132}$ and do not limit registerable offenses to felonies. ${ }^{133}$ Finally, at least twenty-eight states subject juveniles to registration. ${ }^{134}$

While the statutory law of all states contains a laundry list of specified crimes warranting registration, several states supplement their list with open-ended language that substantially broadens the scope of registration. For instance, in Minnesota a court can require registration for any conviction "arising out of the same set of circumstances"

${ }^{122}$ KAN. STAT. ANN. § 22-4902(a) (5) (A) (Supp. 2004).

123 OR. REv. STAT. ANN. § 181.594(2) (j)-(k) (Supp. 2005).

${ }^{124}$ S.D. CODIFIED LAWS $§ 22-22-30(11)$, (14) (2004).

${ }^{125}$ S.C. CODE ANN. $\$ 23-3-430(\mathrm{C})(10),(12),(14),(17)$, (18) (Supp. 2004).

${ }^{126}$ IDAHO CODE ANN. § 18-8304(a) (2004 \& Supp. 2005); LA. REV. STAT. ANN. § 15:541(14.1) (2005).

127 N.D. CENT. CODE $§ 12.1-32-15$ (1) (e) (Supp. 2005).

${ }^{128}$ CONN. GEN. STAT. ANN. $§ \S 54-250(5),-251$ (a) (West 2001 \& Supp. 2005).

${ }^{129}$ See, e.g., ALASKA STAT. $\$ \S 11.61 .127,12.63 .010,12.63 .100(6)(\mathrm{C})(\mathrm{v})$ (2004) (incorporating possession of child pornography in the definition of sex offenses requiring registration); MO. ANN. STAT. \$ 589.400(1) (2) (West Supp. 2005) (mandating registration for conviction of possessing child pornography); TEX. CODE CRIM. ProC. ANN. art. 62.001(5)(B) (Vernon, Westlaw through 2005 2d Called Session of the 79th Legislature) (same). For its part, federal law requires registration for convictions relating only to the "production and distribution of child pornography." 42 U.S.C.A. $\S$ 14071(a) (3) (A) (viii) (West 2005).

${ }^{130}$ KAN. STAT. ANN. § 22-4902(d) (5) (Supp. 2004).

1312005 Minn. Sess. Law Serv. 136 (West) (amending Minn. Stat. Ann. § 243.166(1) (a) (1) (ii) (West 2003 \& West Supp. 2005)).

${ }^{132}$ MONT. CODE ANN. § 46-23-502(9) (a) (2003).

133 See, e.g., ALASKA STAT. \$ 12.63.100(6) (C) (ii), (vi) (2004) (requiring registration for conviction of a Class A misdemeanor); N.D. CENT. CODE $§ 12.1-32-15$ (2) (b) (Supp. 2005) (requiring registration for those found guilty of misdemeanor sexual offenses); WASH. REV. CODE ANN. § 9A.44.130(9) (a) (v) (West Supp. 2005) (including certain gross misdemeanors in the definition of "sex offense").

${ }^{134}$ Elizabeth Garfinkle, Comment, Coming of Age in America: The Misapplication of Sex-Offender Registration and Community-Notification Laws to Juveniles, 91 CAL. L. REV. 163, 177-78 (2003). 
as a charged felony offense that statutory law specifies as requiring registration. ${ }^{135}$ As a result, so long as a statutorily enumerated offense is charged by Minnesota prosecutors, and a conviction for some offense (even a misdemeanor) results, registration is required if the "arising out of" requirement is satisfied. ${ }^{136}$ Other states require registration when one is convicted of a non-enumerated offense and the underlying behavior is "sexually motivated" or committed with a "sexual purpose" or for "sexual gratification." ${ }^{137}$ For its part, Alabama targets "generally any act of sexual perversion involving a member of the same or the opposite sex, or any sexual abuse of any member of the same or the opposite sex...."138 South Carolina permits registration for non-statutorily specified offenses if "good cause is shown by the [prosecutor]." 139 Iowa requires registration of those who have "committed" offenses that would be "indictable" under its law. ${ }^{140}$

1352005 Minn. Sess. Law Serv. 136 (West) (amending MinN. STAT. AnN. § 243.166(1) (a) (1) (West 2003 \& West Supp. 2005)).

${ }^{136}$ Boutin v. LaFleur, 591 N.W.2d 711, 715-16 (Minn. 1999). As a result, as the Eighth Circuit recently acknowledged:

$[\mathrm{T}]$ he statute may lead to unfair results in some cases. We note, for example, the statute would require registration of a person accused of both a predatory offense and a non-predatory offense arising out of the same set of circumstances who exercised his right to a trial and was acquitted of the predatory offense but convicted of the non-predatory one.

Gunderson v. Hvass, 339 F.3d 639, 645 (8th Cir. 2003). For more pointed criticism of the law, in particular the "enormity of the potential unchecked power" it reposes in prosecutors, see State v. Newell, No. C1-02-310, 2002 WL 31253657, at *2 (Minn. Ct. App. Oct. 8, 2002).

137 See, e.g., CAL. PenAl Code $\$ 290$ (a) (2) (E) (West 1999 \& Supp. 2005) (requiring registration if the court finds "that the person committed the offense as a result of sexual compulsion”); CONN. GEN. STAT. ANN. § 54-254(a) (West 2001 \& Supp. 2005) (including "any felony that the court finds was committed for a sexual purpose"); KAN. STAT. ANN. § 22-4902(c) (14) (Supp. 2004) (including "sexually motivated offenses"); NEV. REV. STAT. ANN. § 179D.410(18) (LexisNexis Supp. 2001) (including "sexually motivated" offenses); WASH. REV. CODE §§ 9A.44.130(9) (a), 9.94A.030(39) (West 2000 \& Supp. 2005) (requiring registration if the crime was committed "for the purpose of his or her sexual gratification"); see also, e.g., MD. CODE ANN., CrIM. Proc. $§ 11$ 701(d) (7) (LexisNexis 2001 \& Supp. 2003) (requiring registration for "a crime that by its nature is a sexual offense against a person under the age of 18 years"); N.D. CENT. CODE $\S 12.1-32-15(2)$ (e) (Supp. 2005) (requiring registration when the "individual demonstrated mental abnormality or sexual predatory conduct in the commission of the offense").

138 ALA. CODE $\S 13 A-11-200$ (1994).

139 S.C. CODE ANN. § 23-3-430(D) (Supp. 2004).

${ }^{140}$ IOWA CODE ANN. § 692A.1(5) (o), (9) (e) (West Supp. 2005). 


\section{Approaches to Registration}

The variation just described, both in terms of offenses warranting registration and broad language permitting courts to require registration on an ad hoc basis, creates challenges for sister jurisdictions intent on ensuring that itinerant offenders not evade accountability for their past misconduct. States have adopted different approaches to resolving whether individuals with foreign convictions must register upon arrival in their newly adopted state. As with recidivist laws, one sees two basic camps: internal and external. ${ }^{141}$

Thirty-five jurisdictions use an internal approach requiring that newly arrived ex-offenders register in the forum only if the foreign predicate comes within the ambit of registerable offenses specified by the forum. ${ }^{142}$ Registration laws, like their recidivist counterparts, dif-

${ }^{141}$ With both approaches, whether a foreign conviction warrants registration is a question of law for the court to decide. See, e.g., State v. Kunz, 100 P.3d 26, 28 (Ariz. Ct. App. 2004) ("Whether the trial court properly applied [the state registration statute] is a question of law...."); State v. Chun, 76 P.3d 935, 942 n.12 (Haw. 2003) (“[W] hether a person must register as a 'sex offender' ... is a question of law.").

The process for individuals categorized by other states as "sexually violent predators," a subgroup thought uniquely dangerous and subject to the most draconian registration (and notification) requirements, is more procedurally involved. See supra notes 116-18 and accompanying text (discussing the federal minimum requirements for such determinations). In Ohio, for instance, the court must first assess whether the foreign conviction is "substantially similar" to an Ohio offense requiring predator designation. If so, the individual is entitled to a hearing in which he has the burden of showing by clear and convincing evidence that he is not likely to commit another sexually oriented offense in the future. The court's ultimate decision must be supported by findings of fact and conclusions of law. State v. Pasqua, 811 N.E.2d 601, 606 (Ohio Ct. App. 2004).

${ }^{142}$ ALA. CODE § 13A-11-200(b) (1994 \& Supp. 2004); ALASKA STAT. § 12.63.100(6) (2004); ArIz. Rev. StAT. ANN. § 13-3821 (2001 \& Supp. 2004); ConN. GEN. STAT. ANN. § 54-253(a) (West 2001 \& Supp. 2005); DEL. CODE ANN. tit. 11, § 4120 (e) (1) (2001); D.C. Code ANN. $§ 22-4001(6),(8)$ (G) (LexisNexis 2001 \& Supp. 2005); GA. CodE ANN. $\S$ 42-1-12(a) (7) (1997 \& Supp. 2005); 2005-1 Haw. Rev. Stat. Ann. Adv. Legis. Serv. 251 (LexisNexis) (amending HAW. REv. STAT. 846E-1 (1997 \& Supp. 2004)); IdAHO CODE ANN. § 18-8304(1) (b) (2004 \& Supp. 2005); 730 Ill. COMP. STAT. ANN. 150/2(A) (1), (2)(C) (West Supp. 2005); IND. CODE ANN. § 5-2-12-4(14) (West 2002 \& Supp. 2004); IOwa Code ANN. § 692A.1(5)(o) (West 2003 \& Supp. 2005); Ky. ReV. STAT. ANn. § 17.500(6) (c) (LexisNexis 2003); LA. REV. STAT. ANN. § 15:541(14.1) (2005); MD. CODE ANN., Crim. Proc. $§ 11-701$ (b) (4) (LexisNexis 2001 \& Supp. 2003); MASS. ANN. LAWS ch. 6, § 178C (LexisNexis 1999 \& Supp. 2005); 2005 Minn. Sess. Law Serv. 136 (West) (amending MinN. STAT. ANN. § 243.166(1)(a)(4), (d)(1) (West 2003 \& West Supp. 2005); 2005 Neb. Laws 713 (amending Neb. Rev. STAT. § 29-4003(1) (b) (1996 \& Supp. 2004)); N.H. REV. STAT. ANN. § 651-B:1(III) (b) (LexisNexis 1996 \& Supp. 2004); N.J. STAT. ANN. § 2C:7-2(b) (3) (West 1995 \& Supp. 2005); 2005 N.M. Laws 279 (amending N.M. Stat. ANn. § 29-11A-3(A)(2) (LexisNexis 2001)); N.C. GEN. Stat. § 14208.6(4) (b), (c) (2003); N.D. CENT. CODE $\$ 12.1-32-15$ (3) (b) (1997); OHIO REV. CODE 
fer in their eligibility language, variously requiring registration if the foreign conviction "would" require registration if it occurred in the forum, ${ }^{143}$ or if the foreign conviction is "reasonably" ${ }^{144}$ or "substantially" 145 the same or "similar" While many jurisdictions narrowly construe the language of their internal approach laws, ${ }^{147}$ not all do so. As recently noted by the D.C. Court of Appeals, statutory language requiring registration for "substantially similar" offenses was "designed to overcome difficulties caused by " $\mathrm{t}]$ he variations among different jurisdictions in the termi-

ANN. § 2950.01(D)(f), .04(A) (3) (b) (LexisNexis 2003 \& Supp. 2005); OKLA. STAT. ANN. tit. 57, § 583(B) (West Supp. 2005); R.I. GEN. LAwS § 11-37.1-2(e) (2002 \& Supp. 2004); Tenn. Code Ann. § 40-39-202(2) (1997 \& Supp. 2001); Tex. Code Crim. Proc. ANN. art 62.001(5)(H)-(I), 6(E) (Vernon, Westlaw through 2005 2d Called Session of the 79th Legislature); UTAH CODE ANN. § 77-27-21.5(1)(e) (ii) (2003); VT. STAT. ANN. tit. 13, §5401(10)(C), (11) (Supp. 2004); VA. CODE ANN. § 9.1-902(B) (Supp. 2005); WASH. REv. CODE ANN. §§ 9A.44.130(9)(iv), .140(5) (b) (iii)(E) (West 2000 \& Supp. 2005); W. VA. CODE ANN. § 15-12-2 (LexisNexis 2004 \& Supp. 2005); WIS. STAT. ANN. § 301.45(1d) (am) (1) (West 2005); WYO. STAT. ANN. § 7-19-301 (a) (ii), (iv) (2005).

${ }^{143}$ See, e.g., ARIz. REv. STAT. ANN. § 13-3821(A) (2001 \& Supp. 2004) (requiring registration for commission of an offense in a foreign jurisdiction that "would be a [specified] violation or attempted violation" if committed in Arizona).

${ }^{144}$ See, e.g., MONT. CODE ANN. § 46-23-502(6)(b) (2003) (requiring registration where foreign conviction is "reasonably equivalent"); N.H. REV. STAT. ANN. § 651B:1(III) (b) (LexisNexis 1996 \& Supp. 2004) (providing for registration for "reasonably equivalent" offenses).

${ }^{145}$ See, e.g., D.C. CODE ANN. § 22-4001(8)(G) (LexisNexis 2001 \& Supp. 2005) (mandating registration where foreign conviction is "substantially similar"); $2005 \mathrm{Neb}$. Laws 713 (amending NEB. REV. STAT. § 29-4003(1) (b) (1996 \& Supp. 2004)) (requiring registration where offense is "substantially equivalent" to one in Nebraska); TEX. Code Crim. Proc. ANN. art. 62.001(5)(H) (Vernon, Westlaw through 2005 2d Called Session of the 79th Legislature)) (commanding registration where the out-of-state conviction was "substantially similar" to the enumerated offense in Texas).

${ }^{146}$ See, e.g., ALASKA STAT. $\$ 12.63 .100(6)$ (2004) (requiring registration for convictions under the "similar law of another jurisdiction"); VA. CODE ANN. § 9.1-902(B) (Supp. 2005) (mandating registration where a conviction constitutes a "similar offense" to those enumerated in Virginia).

${ }^{147}$ See, e.g., Cain v. State, 872 A.2d 681, 692 (Md. 2005) (holding that elements of the crime of conviction, not underlying facts, must qualify as a sexual offense against a minor, as required by registration law). The rule of lenity, of course, applies only to criminal law provisions, which, courts have concluded, sex-offender registration is not. However, while registration itself might be nonpunitive for constitutional purposes (e.g., double jeopardy), failure to satisfy a registration requirement is a criminal offense, warranting narrow legal construction in the instance of legislative ambiguity. See People v. Franklin, 975 P.2d 30, 33 (Cal. 1999) (applying "favorable construction" to a sex offender registration law, given that violation of the law is a penal offense); $c f$. United States v. Concha, 233 F.3d 1249, 1256-57 (10th Cir. 2000) (applying the rule of lenity to a federal law that criminalizes possession of firearms by convicted felons). 
nology and categorizations used in defining sex offenses." "148 As a result, the court explained that the statute

eschews "element-by-element comparisons" between offenses in D.C. and similar offenses elsewhere in favor of requiring persons in the District of Columbia to register so long as "they have been convicted under the laws of other jurisdictions of crimes involving sexual assault or crimes involving sexual abuse or sexual exploitation of children, or of inchoate offenses that aimed at such conduct." . . . Thus, the Council did not intend the term "substantially similar" to be construed narrowly or restrictively. Rather, the Council contemplated that the term would be given a broad construction to effectuate the goals of the legislation.

Often the comparison effort is easy enough, readily resulting in a conclusion about whether registration is required. However, because state substantive laws vary to such a significant extent, courts commonly face a far more difficult analytic task of a comparative law nature-a process again made more difficult by the frequent need to construe aged laws and physically and temporally remote conviction records. ${ }^{150}$ In Texas, uniquely, the Department of Public Safety is charged with the responsibility of determining whether out-of-state convictions warrant registration in Texas, with appeals being made to "a district court in Travis County." partment of Public Safety

shall provide or make available to each prosecuting attorney's office in the state: (1) the criteria used in making a determination [of substantial similarity]; and (2) any existing record or compilation of offenses under the laws of another state ... that the department has already determined

${ }^{148}$ In re Doe (“S.D.”), 855 A.2d 1100, 1104 (D.C. 2004) (quoting COUNCIL OF D.C. COMM. ON THE JUDICIARY, REPORT ON BILL 13-350, at 21 (1999), which discusses the legislative history of D.C. CODE ANN. § 22-4001(8) (G)).

${ }^{149} I d$. at 1104-05 (emphasis added in opinion) (quoting COUNCIL OF D.C. COMM. ON THE JUDICIARY, supra note 148, at 21 (1999)); see also In re R.B., 870 A.2d 732, 739 (N.J. Sup. Ct. App. Div. 2005) (comparing "essential elements" and "underlying purposes" of offenses, but stating that "[b] ecause the elements of the offense cannot be viewed in a vacuum, to make this determination may entail examining the facts underlying the offense as charged in the indictment").

${ }^{150}$ See, e.g., State v. Kuntz, 100 P.3d 26, 30 (Ariz. Ct. App. 2004) (holding that a 1981 Minnesota conviction for criminal sexual conduct in the third degree did not require Arizona registration because, inter alia, it was possible that conviction did not involve lack of consent required by the analogous Arizona law); Roe v. Attorney Gen., No. 99-2706-H, 1999 WL 1260188, at*3 (Mass. Super. Ct. Nov. 23, 1999) (holding that a 1983 Florida conviction for indecent assault did not require registration in Massachusetts because Florida law lacked the battery element contained in Massachusetts law).

${ }^{151}$ Tex. Code Crim. Proc. AnN. art. 62.003(a), (c) (Vernon, Westlaw through 2005 2d Called Session of the 79th Legislature). 
to contain elements that are substantially similar to the elements of offenses under the laws of this state. ${ }^{152}$

Sixteen jurisdictions use an external approach. ${ }^{153}$ In addition to specifying offenses warranting registration, external approach states require registration if the foreign jurisdiction where the conviction occurred required registration, regardless of whether it would warrant registration in the forum. ${ }^{154}$ Moreover, in several states otherwise us-

${ }^{152} I d$. art. $62.003(\mathrm{~b})$

${ }^{153}$ ARK. CODE ANN. § 12-12-903(12)(A) (iii) (b) (2003 \& Supp. 2005); CAL. PENAL CODE $§ 290$ (a) (2) (D) (iii), (iv) (West 1999 \& Supp. 2005); COLO. REV. STAT. § 16-22103(3) (2004); Fla. STAT. ANN. § 943.0435(1) (a)(3) (West Supp. 2005); KAN. STAT. ANN. § 22-4902(a) (6) (Supp. 2004); 2005 Me. Legis. Serv. 423 (West) (amending ME. REv. STAT. ANN. tit. 34-A, §§ 11202, 11223 (Supp. 2004)); Mich. COMP. LAWS ANN. § 28.723(3) (1)(d) (West 2004); MISS. CODE ANN. § 45-33-23(g) (xiv) (West Supp. 2004); Mo. ANN. STAT. § 589.400(1)(5) (West 2003 \& Supp. 2005); MonT. CodE ANN. § 4623-502(6) (b) (2005); Nev. REv. STAT. ANN. § 179D.410(20) (LexisNexis Supp. 2001); N.Y. CORRECT. LAW § 168-a(2)(d), (3) (b) (McKinney 2003 \& Supp. 2004); Or. Rev. STAT. \$ 181.597(2)(c) (2003); 42 PA. CONS. STAT. ANN. § 9795.2(b) (4) (West Supp. 2005); 2005 S.C. Acts 141 (amending S.C. CODE ANN. § 23-3-430(A) (Supp. 2004)); S.D. CODIFIED LAWS § 22-22-30(18) (2004 \& Supp. 2005).

Texas law has an external aspect inasmuch as it requires registration of offenders who enter Texas subject to foreign state registration, when Texas has entered into a "reciprocal registration agreement" with the other state. See TEX. CODE CrIM. Proc. ANN. art. 62.001(10)(A) (i) (Vernon, Westlaw through 2005 2d Called Session of the 79th Legislature). Texas law provides that the Department of Public Safety "may negotiate and enter into a reciprocal registration agreement with any other state to prevent residents of this state and residents of the other state from frustrating the public purpose of the registration of sex offenders by moving from one state to the other." Id. art. 62.052 (c). If such an agreement is in place, immigrants required to register in the other state are deemed "extrajurisdictional registrants" in Texas, presuming they are not otherwise required to register under Texas law. See id. art. 62.001(10). These individuals, in turn, must remain registered for the time period prescribed by the foreign state's registration regime. Id. art. 62.052(b)

154 See, e.g., Miss. CODE ANN. § 45-33-23(g) (xiv) (West Supp. 2004) (including among the offenses for which registration is required " $[\mathrm{a}]$ ny offense resulting in a conviction in another jurisdiction ... for which registration is required in the jurisdiction where the conviction was had"); NEV. REV. STAT. ANN. § 179D.410(20) (LexisNexis Supp. 2001) (categorizing as a sexual offense "[a]n offense of a sexual nature committed in another jurisdiction, whether or not the offense would be an offense listed in this section, if the person ... has been required by the laws of that jurisdiction to register"); OR. REV. STAT. $§ 181.597$ (2) (c) (2003) (requiring registration of "a person required to register in another state for having committed a sex offense in that state regardless of whether the crime would constitute a sex crime in this state"); 2005 S.C. Acts 141 (amending S.C. CODE ANN. § 23-3-430(A) (Supp. 2004)) (requiring registration for "an offense for which the person was required to register in the state where the conviction or plea occurred").

California's law, like Colorado's external-based recidivist law, see supra note 92, specifies that particular foreign convictions will not warrant registration in California, even if they triggered registration in the foreign state. See CaL. PEnal Code $\S$ 
ing an internal approach, the external approach is used with particular offenders-for instance, temporary visitors as a result of educational or work arrangements. ${ }^{155}$

By adopting the external approach, jurisdictions avoid the difficult case-by-case comparative analysis marking the internal approach. New York (which employs an internal approach for recidivism) ${ }^{156}$ adopted the external approach to registration in 1999 when it overhauled its Megan's Law. Evincing the same concern voiced by the D.C. Court of Appeals, ${ }^{157}$ one New York court interpreting the new law opined that the amendment was necessary "because '[t]he present language of the statute [i.e., the "essential elements" test] requires a detailed analysis of the statutes in other jurisdictions to determine whether registration is required in New York State."”158 The amendment, in short, was consistent with the Legislature's intent to expand the scope of coverage vis-à-vis out-of-state offenders. ${ }^{159}$

290 (a) (2) (D) (iii), (iv) (West 1999 \& Supp. 2005) (excluding foreign convictions that are the "equivalent" of indecent exposure, unlawful sexual intercourse, incest, and sodomy and oral copulation between consenting adults).

For its part, federal law also endorses an external approach. See 42 U.S.C. $\S$ 14072(g) (3) (2000) (requiring registration of a person "required to register . . under a State sexual offender offender registration program ... who changes address to a State other than the State in which the person resided at the time of the immediately preceding registration"). As a result, all states in theory are obliged to use an external approach (presuming they wish to receive federal funds). However, this aspect of the federal Megan's Law apparently has not been utilized, so in practical terms states remain free to adopt whichever approach they wish.

${ }^{155}$ See, e.g., LA. REV. STAT. ANN. § 15:542.1(H) (6) (2005) (applying the external approach to students); MD. CODE ANN., CRIM. PROC. § 11-704(7) (LexisNexis 2001 \& Supp. 2003) (applying the external approach to workers and students); 2005 R.I. Pub. Laws 05-410 (amending R.I. GEN. LAWS § 11-37.1-3(b) (2002 \& Supp. 2004)) (applying the external approach to workers and students); VA. CODE ANN. § 9.1-905(B) (Supp. 2005) (same).

${ }^{156}$ See supra note 54 and accompanying text; see also People v. Pacheco, 426 N.Y.S.2d 57, 59 (App. Div. 1980) (quoting legislative history to the effect that change from an external to an internal approach for recidivism was motivated by the desire for "a fairer and more logical approach").

${ }^{157}$ See supra notes $148-49$ and accompanying text.

${ }^{158}$ In re Nadel, 724 N.Y.S.2d 262, 270 (Sup. Ct. 2001) (citation omitted). In the event the prior conviction is not for a felony triggering registration in the foreign jurisdiction, the court must undertake the same "essential elements" test used in assessing recidivism. Id. at 269-70.

${ }^{159}$ Id. at 271; cf. State v. Villanueva, 118 P.3d 179, 182 (Mont. 2005) ("While presumably similar, the definition of 'sexual offender' in all other states will not be identical to the definition enacted by the Montana Legislature. If only those offenders satisfying Montana's definition were required to register, [recent amendments] ... would be rendered meaningless."). 


\section{Summary}

As discussed, U.S. criminal justice has become more cognizant of the benefits of interconnection over the past century. By reaching out to their fellow sovereigns, as they are free to do, ${ }^{160}$ states are better able to fulfill their goals of holding ex-offenders accountable for past misconduct and achieving a greater quantum of social control over such individuals, whose foreign convictions signify an unwillingness to abide by criminal prohibitions.

The means of achieving this coordination have evolved over time. With respect to recidivist enhancements, while initially states paid no heed to foreign convictions, eventually they came to see the appeal of ascribing "equal dignity" to them. ${ }^{161}$ By 1939, one commentator lauded the use of the external approach in a then-majority of states, noting the "complications" of the internal approach and the "doubtful advantage of giving full effect to local policy." 162 Today, over sixty years later, states have gravitated back to the internal approach.

Compulsory registration has also evolved over time. Early on, registration laws were enacted by municipalities and typically targeted excriminal offenders more generally. ${ }^{163}$ Today, the laws focus on particular ex-offenders (typically those convicted of sex offenses) ${ }^{164}$ and have been enacted by all fifty states and the District of Columbia, going a long way toward achieving the interconnected surveillance system envisioned by the federal government. ${ }^{165}$

${ }^{160}$ See Clark v. Gladden, 432 P.2d 182, 185 (Or. 1967) ("No state is required to take notice of foreign convictions .... Each state is free to give foreign convictions such force as it deems proper in the administration of local sentencing policy.").

${ }^{161}$ See supra notes 44-47 and accompanying text.

${ }^{162}$ Allen, supra note 44 , at $181-82$.

${ }^{163}$ See supra notes 102-06 and accompanying text.

${ }^{164}$ California, the first state to require registration of sex offenders in particular, also requires registration of persons convicted of gang-related offenses, drug law offenders, and arsonists. See CAL. PENAL CODE $§ 186.32$ (West Supp. 2005) (requiring registration of those convicted of juvenile and adult gang offenses); id. § 457.1 (West 1999 \& Supp. 2005) (requiring registration of arsonists); CAL. HEALTH \& SAFETY CODE $\S 11590$ (West 1991 \& Supp. 2005) (requiring registration of drug offenders). To date, however, the legislature has seen fit to tie only the drug offense registration law to foreign convictions. See id. $\$ 11590$ (a) (adopting an internal approach and mandating registration if the person is convicted of an offense that "if committed or attempted in this state" would be covered by the statute).

${ }^{165}$ See supra note 23 and accompanying text. For further discussion of this effect, with an analogy made to Jeremy Bentham's infamous, yet mythical, penal Panopticon with its all-seeing central tower and inspector's lodge, see Wayne A. Logan, Federal Habeas in the Information Age, 85 MINN. L. REv. 147, 195-99 (2000) (describing how registration and community notification conscript citizens and offenders alike to achieve 
Unlike recidivist laws, registration laws were enacted with a ready capacity to accommodate immigrant offenders, whether by means of the internal or external approach. While at present a majority of jurisdictions employ an internal approach, ${ }^{166}$ it should not come as a surprise to see that, unlike the evolution of recidivist laws, the external approach is increasingly employed, prompted by legislative desire to broaden the net of social control over itinerant sex offenders. New York, for instance, while taking an internal approach for recidivism, opted for the external approach when dealing with the registration of sex offenders moving into the state. ${ }^{167}$ In so doing, it consciously sought to increase the coverage of its registration law, consistent with the avowed remedial intent of affording greater protection to New York's citizens. ${ }^{168}$ As the laws evolve, broad judicial construction of internal approach laws, such as has occurred in the District of Colum-

surveillance and social control). Ironically, while the federal government strongarmed the states into complying with its own registration-criteria law, it actually served to make their registration duties more difficult, at least with respect to federally convicted offenders. This is because, as a practical matter, no registration system now exists under federal law because states, bowing to federal fiscal pressure, have fulfilled federal registration-related requirements. See 42 U.S.C. $\$ 14072$ (a), (c) (2000) (requiring federal registration for sex offenders only if a state has not established a "minimally sufficient" registration regime). As a result, the external approach is of no utility for federal crimes, and states like New York must undertake a "complicated" and "painstaking" comparison of state and federal criminal law to assess whether a person convicted of a federal crime must register in New York. In re Nadel, 724 N.Y.S.2d 262, 26769 (Sup. Ct. 2001)

${ }_{166}$ See supra note 142 and accompanying text.

${ }^{167}$ The divergence might be explained by the distinct goals and effects of recidivist and registration laws. Whereas registration is largely proactive, seeking to monitor offenders and deter criminal activity, and costs relatively little to administer, recidivist laws are reactive, punishing new wrongdoing in the forum and carrying significant costs (i.e., increased judicial and correctional resources). New York's use of the external approach for registration of sex offenders is thus perhaps attributable to its contingent nature, which, while allowing for public safety, only incurs major costs when immigrant offenders are prosecuted and convicted for failing to register. In addition, the State's use of the more inclusive, control-oriented external approach for sex offenders in particular is consistent with the uniquely acute fear of, and disdain for, such offenders.

168 See In re Millan, 730 N.Y.S.2d 392, 398 (2001) (emphasizing the court's responsibility to construe the registration law to achieve the legislative objective of public protection), rev'd on other grounds sub nom. People v. Millan, 743 N.Y.S.2d 872 (2002); see also, e.g., Jeremy Pawlowski, Sex Offender Fights Registery [sic], AlBUQUerQue J., July 7, 2005, at 1, available at 2005 WLNR 10663982 (describing the determination of authorities to require the registration of a new resident, despite statutory exception, because the resident was required to register in his former state of residence). 
bia, ${ }^{169}$ will likely become more common, serving to increase the bounds of state social control.

Taken together, the current assemblage of registration and recidivist laws provides a prime example of horizontal federalism, driven by the unique policy concerns presented by itinerant criminal offenders. Unlike the civil justice system, which is chary of embracing foreign outcomes due to concern over the normative policy differences among states, ${ }^{170}$ the criminal justice system is quite willing to lend them weight. In so doing, states are obliged to undertake a unique interpretive enterprise, largely unknown to conflict of laws practice and jurisprudence. ${ }^{171}$ Using an adjudicative approach akin to that mandated in the vertical federalism context by Erie Railroad Co. $v$. Tompkins, ${ }^{172}$ whereby federal courts in civil diversity-of-citizenship cases employ the substantive law of the state in which they sit, ${ }^{173}$ state criminal courts interpret and apply the criminal laws of other states.

This parallel with Erie, however instructive, is problematic though because it understates the actual complexity and ramifications of state interconnection. With recidivist and registration laws, unlike the typical federal civil diversity suit, ${ }^{174}$ the interpreting court is geographically

169 See supra notes 148-49 and accompanying text.

170 See, e.g., White v. Ford Motor Co., 312 F.3d 998, 1017 (9th Cir. 2002) (eschewing consideration of foreign tort recoveries in punitive damages analysis, citing the concern over difficulty in identifying whether the behavior was unlawful in the forum and the fact that "the variation in policies of punishment, even where the conduct is unlawful in all states, amounts to an important distinction in policy"). For a discussion of this asymmetry in judicial consideration of extraterritorial wrongdoing relative to punitive damage awards and recidivist sentences, see Logan, supra note 40, at 1627-35.

${ }^{171}$ The uniqueness of the enterprise is evidenced in the leading treatise in the field, which dedicates less than two pages to the general issue of sister-state enforcement and interpretation of penal law judgments and claims. EUGENE F. SCOLES ET AL., CONFLICT OF LAWS $\$ \$ 3.17$ to .18 (4th ed. 2004).

${ }^{172} 304$ U.S. 64 (1938).

173 Under Erie, when neither the Constitution nor a federal statute controls the claim, federal courts are constrained to apply the substantive law of the state in which they sit, yet follow federal rules on questions of procedure. Id. at 78, 80. Prior to Erie, federal courts in diversity cases endeavored to cobble together a nationally uniform federal common law. In rejecting this effort, the Erie Court noted that "[i]n attempting to promote uniformity of law throughout the United States, the doctrine had prevented uniformity in the administration of the law of the State." $I d$. at 75.

${ }^{174}$ While most often federal courts interpret and apply the substantive law of the state in which they sit, exceptions do arise. For instance, in a choice-of-law situation a federal court will defer to the forum state's relevant law, which can in turn require application of the law of another jurisdiction. See, e.g., Limbach Co. v. Zurich Am. Ins. Co., 396 F.3d 358, 361-62 (4th Cir. 2005) (affirming application of Pennsylvania contracts law on the basis of Virginia's choice-of-law rules). 
distinct from the foreign court where the underlying conviction occurred, which can present unique challenges. ${ }^{175}$ In addition, the parallel risks obscuring an important distinction: unlike in diversity suits, where the federal court invokes the law of the jurisdiction in which it sits, state criminal courts applying registration and recidivist laws effectuate the laws of other states. As a consequence, the criminal laws of respective states cast, as the California Supreme Court recently put it, "shadow[s]" over one another ${ }^{176}$ affecting outcomes well beyond their territorial domains. These "shadows" raise important questions touching on policy and practice and have a very real impact on the liberty of individuals who, as is their right, ${ }^{177}$ can and do move from one state to another. ${ }^{178}$ It is to these issues that the discussion now turns.

\section{THE CHALlENGES AND CONSEQUENCES OF INTERCONNECTION}

The varied approaches discussed above at once bespeak the "fiftylabs" benefits of federalism, and, as states independently seek to hold migrating ex-offenders accountable for their past misconduct elsewhere, some of its problematic effects. Regardless of whether a state employs an internal or external approach, or uses the foreign conviction for assessing recidivism or requiring registration, criminal justice

${ }^{175}$ As a result of this distance, the state criminal court is not only less likely to be familiar with the law, interpretative tenets, and practice of the foreign jurisdiction, but also less likely to benefit from the input of lawyers' counsel because they are not schooled in the foreign state's law and practice. At the same time, this deficit is not ameliorated, given the lack of any right to appeal adverse determinations to the foreign court, and the diminished pressure on the forum court to "get it right" stemming from the monitoring effect that naturally exists when the court interprets and applies its indigenous law in the full view of the local bench and bar.

${ }^{176}$ People v. Laino, 87 P.3d 27, 40 (Cal.), cert. denied, 125 S. Ct. 146 (2004).

177 See City of Chicago v. Morales, 527 U.S. 41, 53-54 (1999) (“[T]he 'right to remove from one place to another according to inclination' is 'an attribute of personal liberty' protected by the Constitution." (quoting Williams v. Fears, 179 U.S. 270, 274 (1900))); Shapiro v. Thompson, 394 U.S. 618, 629 (1969) (“[T] he nature of our Federal Union and our constitutional concepts of personal liberty unite to require that all citizens be free to travel throughout the length and breadth of our land uninhibited by statutes, rules, or regulations which unreasonably burden or restrict this movement.").

${ }^{178}$ The right to travel can of course be lawfully restricted by state-mandated probation and parole conditions. The discussion here, while not necessarily affected by this distinction, primarily focuses on individuals not subject to such restrictions. See Smith v. Doe, 538 U.S. 84, 101 (2003) (distinguishing probationers from ex-offenders subject to sex offender registration, in that the latter "are free to move where they wish and to live and work as other citizens, with no supervision"). 
interconnection carries with it an array of significant practical challenges and consequences.

\section{A. Practical Challenges}

Before a state can utilize a foreign disposition, it must surmount a variety of practical challenges. The most immediate challenge stems from the need to secure and interpret the records of foreign courts, which are often less than crystal clear. As one court put it, consultation of conviction records creates a "Pandora's box" of judicial archival work and reconstruction. ${ }^{179}$ At times it can be hard to answer the fundamental question of whether the foreign conviction resulted in a felony-level disposition, ${ }^{180}$ a process often made even more difficult by ambiguous or incomplete records. ${ }^{181}$

Even when the records themselves do not pose a problem, courts (especially when employing the internal approach) face the challenge of simultaneously interpreting the criminal laws and procedures of other states and their own, a process complicated when foreign convictions are aged, possibly requiring the interpretation of decades-old statutes and supporting legislative commentary from other states. The judicial resources consumed by such interstate statutory interpretation ultimately implicate not just efficiency ${ }^{182}$ but also distributive justice concerns. ${ }^{183}$

${ }^{179}$ Peacock v. Texas, 876 F. Supp. 865, 868 (E.D. Tex. 1995).

${ }^{180}$ See William A. Schroeder, Factoring the Seriousness of the Offense into Fourth Amendment Equations-Warrantless Entries into Premises: The Legacy of Welsh v. Wisconsin, 38 U. KAN. L. REV. 439, 508 (1990) (noting that the felony/misdemeanor distinction is uncertain because "[i]n many jurisdictions the same conduct can be either a misdemeanor or felony depending on how it is prosecuted or depending on the institution to which the offender is sentenced"). For more on the indistinct lines, both historic and contemporary, distinguishing felonies and misdemeanors, see United States $v$. Watson, 423 U.S. 411, 438-40 (1976) (Marshall, J., dissenting) (describing the substantive changes in the kinds of crimes deemed felonies and misdemeanors); JEROME HALL, THEFT, LAW AND SOCIETY 300-01 (1935) (exploring historical distinctions between felonies and misdemeanors).

${ }^{181}$ See supra notes 68-72 and accompanying text; see also Quentin Brogdon, Admissibility of Criminal Convictions in Civil Cases, 61 TEx. B.J. 1112, 1116-17 (1998) (noting that "criminal records are in abysmally poor shape across the country, and often inaccessible even to the law enforcement officials who need them").

${ }^{182}$ Cf. Small v. United States, 125 S. Ct. 1752, 1756 (2005) (rejecting consideration of a prior foreign nation conviction in part because it would require judges and prosecutors " $[\mathrm{t}] \mathrm{o}$ somehow weed out inappropriate foreign convictions," a task that is "not easy for those not versed in foreign laws to accomplish"). For more on the inefficiencies imposed on legal systems as a result of having to learn and apply varied legal 
These difficulties, in turn, exacerbate ongoing concerns over recidivist enhancement laws in particular. While commentators have long questioned these laws on moral and philosophical grounds, ${ }^{184}$ attention of late has focused on the means by which enhancement eligibility determinations are reached. Today, the prevailing view is that the Supreme Court's decision in Apprendi v. New Jersey ${ }^{185}$ requires that the existence of a prior conviction need not be established beyond a reasonable doubt nor proven to the satisfaction of a jury. ${ }^{186}$ While a handful of states have seen fit to extend such rights to defendants, ${ }^{187}$ the vast majority have not, leaving it to the courts to determine whether enhancement based on a prior conviction is in order. ${ }^{188}$

norms, see Michael P. Van Alstine, The Costs of Legal Change, 49 UCLA L. REV. 789 (2002).

${ }^{183}$ Cf. Mitchell v. Great Works Milling \& Mfg. Co., 17 F. Cas. 496, 499 (C.C.D. Me. 1843) (Story, J.) (rejecting the requirement that federal suits be brought in state court because it "may most materially interfere with the convenience of their own courts, and the rights of their own citizens, and be attended with great expense to the state, as well as great delays in the administration of justice").

184 See, e.g., GeORGe P. Fletcher, RETHINking CRIMINAL LAW $§$ 6.6.2, at 465-66 (1978) (questioning the propriety of recidivist enhancement laws in liberal society); Markus D. Dubber, Recidivist Statutes as Arational Punishment, 43 BUFF. L. REv. 689 (1995) (arguing that enhancement laws lack penological justification).

${ }^{185} 530$ U.S. 466 (2000). While insisting that any fact that increases the penalty for an offense beyond the statutory maximum must be submitted to a jury and proven beyond a reasonable doubt, the Apprendi majority carved out an exception for "the fact of a prior conviction." Id. at 490 .

${ }^{186}$ See, e.g., People v. Johnson, 74 P.3d 349, 355-56 (Colo. Ct. App. 2002) (citing Apprendi for the proposition that the defendant is not entitled to a jury trial on habitual criminal counts); State v. Smith, 75 P.3d 934, 937 (Wash. 2003) (concluding that prior convictions need not be proven beyond a reasonable doubt).

${ }^{187}$ See, e.g., IND. CODE ANN. § 35-50-2-8(g) (West 2004) (requiring proof beyond a reasonable doubt that the person accumulated two prior unrelated felony convictions); MASS. ANN. LAWS ch. 278, § 11A (LexisNexis 2002) (entitling a defendant to a trial by jury on the existence of a prior conviction); N.C. GEN. STAT. $§ 14-7.5$ (2003) (requiring trial by jury to find a person guilty of being a habitual felon); S.D. CODIFIED LAWS $§ 22-7-12$ (2004 \& Supp. 2005) (requiring a defendant to be informed of her right to a trial by jury on the issue of whether she is the same person as alleged in the habitual criminal information); W. VA. CODE ANN. § 61-11-19 (LexisNexis 2000) (requiring a trial by jury if the defendant does not admit to a record of previous conviction).

${ }^{188}$ See supra note 55 and accompanying text; cf. United States v. Patterson, 412 F.3d 1011, 1016 (8th Cir. 2005) (deeming the characterization of a prior state conviction as "violent," justifying enhancement, a legal question for the court), cert. denied, 74 U.S.L.W. 3274 (U.S. Oct. 31, 2005) (No. 05-6668); United States v. Orduno-Mireles, 405 F.3d 960, 962 (11th Cir. 2005) (deeming determination of whether a prior state conviction was a "crime of violence," justifying enhancement, a legal question for the court). 
In the run-of-the-mill case challenging a prior conviction, a defendant might assert that she was not the individual previously convicted or that the supporting records are inauthentic or wrong. ${ }^{189} \mathrm{Al}-$ ternatively, a defendant might challenge an enhancement based on a prior adjudication, such as one in juvenile court, arguing that it did not qualify as a sufficiently reliable "conviction" under Apprendi. ${ }^{190}$

When courts look to foreign convictions, especially pursuant to the internal approach, however, their work is not limited to the largely ministerial determination of the "fact" of a prior conviction. ${ }^{191}$ In internal approach jurisdictions that focus strictly on the elements of the foreign offense conviction (as manifest by the verdict or plea based on established facts of record) ${ }^{192}$ enhancement eligibility can be a complex comparative law question for the sentencing court to resolve. ${ }^{193}$ However, in jurisdictions permitting analysis to go beyond the verdict or plea, a potential constitutional concern is presented because a legally material, disputed fact (i.e., behavior underlying the prior conviction that possibly triggers the forum's recidivist law) was not established by a jury beyond a reasonable doubt or admitted by the defendant.

Such constitutional concern is especially likely in the wake of Shepard $v$. United States, ${ }^{194}$ which recently limited the evidentiary record sentencing courts can consult when deciding if a prior conviction based upon a guilty plea qualifies for a mandatory sentence enhancement. Under Shepard, a court is permitted to consult only the statutory definition of the crime of conviction, the charging document, the plea agreement and colloquy, and any specific findings by the trial

${ }^{189}$ See, e.g., People v. Belmares, 130 Cal. Rptr. 2d 400, 406-07 (Cal. Ct. App. 2003) (rejecting an identity-based claim as well as the assertion that the defendant had a constitutional right to a jury determination of the question).

${ }^{190}$ See, e.g., State v. Brown, 879 So. 2d 1276, 1289 (La. 2004) (refusing to enhance an adult's sentence because the prior juvenile adjudication was obtained without right to jury trial, thus undercutting its constitutional reliability).

${ }^{191}$ In external approach jurisdictions, the role of the sentencing court is essentially ministerial insofar as the court's job is to determine whether the foreign conviction warranted felony status in the foreign jurisdiction.

${ }^{192}$ See supra note 68 and accompanying text.

${ }^{193}$ See, e.g., State v. Heath, 7 P.3d 92, 93 (Ariz. 2000) (deeming determination of whether a foreign felony conviction qualifies for enhancement to be a question of law for the court, which is unaffected by the defendant's admission of the conviction's existence).

194 125 S. Ct. 1254 (2005). 
court to which the defendant assented. ${ }^{195}$ While to date only one state appellate court has agreed that fact-finding by courts outside the formal record is constitutionally problematic (in a decision decided before Shepard) ${ }^{196}$ in the future such challenges will likely become successful mainstays of immigrant ex-offenders who face enhancements.

Moreover, while Shepard refused to renounce the Apprendi "prior conviction" exception, it did cast serious constitutional doubt upon it. ${ }^{197}$ Should this doubt someday evolve into the Court's outright rejection of the exception, as urged by commentators, ${ }^{198}$ then the aforementioned resource concerns would be amplified because juries would be charged with making factual determinations on all prior convictions (in-state and out-of-state alike). ${ }^{199}$

\section{B. Notice}

The aforementioned interpretive challenges, difficult enough for the legal system itself, can present significant problems for migratory ex-offenders, who typically are not schooled in the niceties of statutory interpretation and construction. While of course it is axiomatic that ignorance of the law does not qualify as an excuse, ${ }^{200}$ in theory requir-

${ }^{195} I d$. at 1263. In Shepard, the Court rejected the government's argument that sentencing courts should be able to consider police reports or evidence advanced by police in applying for criminal complaints in the earlier case. Id. at 1260.

${ }^{196}$ See State v. Ortega, 84 P.3d 935, 939 (Wash. Ct. App. 2004) (holding that "underlying facts [of a prior Texas conviction] that were not found by the trier of fact beyond a reasonable doubt may not be used to increase the penalty of a subsequent conviction"), review denied, 119 P.3d 852 (Wash. 2005).

197 See Shepard, 125 S. Ct. at 1264 (Thomas, J., concurring) (noting that past votes of a majority of current Justices signal a willingness to abandon the prior conviction exception).

${ }^{198}$ See, e.g., Colleen P. Murphy, The Use of Prior Convictions After Apprendi, 37 U.C. DAVIS L. REV. 973, 978 (2004) (arguing "that the Constitution guarantees proof beyond a reasonable doubt and a right to a jury trial" to determine the existence of a prior conviction).

${ }^{199}$ If the prior conviction exception is disavowed, more states might be encouraged to adopt the external approach, which requires less in the way of proof for the government: it need only convince the trier of fact beyond a reasonable doubt that the prior conviction exists and warranted felony status in the foreign jurisdiction.

${ }^{200}$ See Cheek v. United States, 498 U.S. 192, 199 (1991) ("The general rule that ignorance of the law or a mistake of law is no defense to a criminal prosecution is deeply rooted in the American legal system."). The pragmatic reason for this view was eloquently captured by Justice Holmes:

It is no doubt true that there are many cases in which the criminal could not have known that he was breaking the law, but to admit [ignorance or mistake as an] excuse at all would be to encourage ignorance where the law-maker has 
ing citizens to learn the nation's patchwork of criminal laws, ${ }^{201}$ notice nevertheless remains a prerequisite of due process. ${ }^{202}$

Notice difficulties are perhaps most pronounced with registration, ${ }^{203}$ which, depending on the jurisdiction, provides as little as two days to determine whether a newcomer must register. ${ }^{204}$ When an individual moves to an external approach state, the task is easy enough: if the foreign jurisdiction required registration, then the newly adopted state does so as well. With internal approach states, however, the individual is forced to undertake what is possibly a quite complex task in statutory interpretation. ${ }^{205}$ Moreover, the task is complicated

determined to make men know and obey, and justice to the individual is rightly outweighed by the larger interests on the other side of the scales.

Oliver Wendell Holmes, JR., The Common LaW 48 (Little, Brown \& Co. 1948) (1881); see also Dan M. Kahan, Ignorance of the Law Is an Excuse-But Only for the Virtuous, 96 MICH. L. REV. 127, 128 (1997) (discussing the moral underpinnings of the "mistake of law" doctrine).

${ }^{201}$ Alexis de Tocqueville, writing 150 years ago, remarked that it was "frightening to see how much diverse knowledge and discernment [federalism] assumes on the part of the governed." AleXIS DE TOCQUEVILle, DEMOCRACY IN AMERICA 164 (J.P. Mayer ed., George Lawrence trans., Doubleday \& Co. 1969) (1850). With the dramatic proliferation in state, federal, and local criminal laws in recent years, one can say with confidence that de Tocqueville would be impressed all the more. See generally Robert C. Ellickson, Taming Leviathan: Will the Centralizing Tide of the Twentieth Century Continue into the Twenty-First?, 74 S. CAL. L. REV. 101, 105-06 (2000) (noting the marked increase in laws by comparing New Haven, Connecticut's laws in the twentieth century to those in the nineteenth).

${ }^{202}$ See Connally v. Gen. Constr. Co., 269 U.S. 385, 391 (1926) (stating that a law so unclear in its substance that citizens "of common intelligence must necessarily guess at its meaning and differ as to its application ... violates the first essential of due process of law"). This is not to say that the law-abiding public at large is especially wellinformed about the criminal law. See JUlian V. ROBERTS \& LORETTA J. STALANS, PUblic OPINION, CRIME, AND CRIMINAL JUSTICE 35-52 (1997) (discussing research highlighting a lack of public familiarity with criminal laws and punishments); William J. Stuntz, Self-Defeating Crimes, 86 VA. L. REv. 1871, 1871 (2000) ("Ordinary people do not have the time or training to learn the contents of criminal codes . . . . Criminal codes therefore do not and cannot speak to ordinary citizens directly.").

${ }^{203}$ See People v. Franklin, 975 P.2d 30, 33 (Cal. 1999) (stating that notice is especially important with registration, "which, to ensure effective compliance, must give clear notice to all registrants of their responsibilities so that laypersons such as defendant can readily understand and properly discharge them"); State v. Chun, 76 P.3d 935, 942 n.12 (Haw. 2003) (urging the legislature to "clearly enumerate the statutory offenses that trigger the registration requirement").

${ }^{204}$ See, e.g., MASs. ANN. LAWS ch. 6, § 178E(g) (LexisNexis Supp. 2005) (requiring registration within two days of moving into the commonwealth).

${ }^{205}$ See, e.g., Creekmore v. Attorney Gen., 341 F. Supp. 2d 648, 666 (E.D. Tex. 2004) (noting that "determining whether elements of one offense are substantially similar to elements of another offense is a difficult task," especially for an "untrained layman"); Roe v. Attorney Gen., No. 99-2706-H, 1999 WL 1260188, at *1 (Mass. Super. Ct. Nov. 23,1999 ) (discussing the difficulty of discerning whether a Florida crime constituted a 
by various special features contained in state laws, including registration requirements triggered by broad statutory language ${ }^{206}$ the varied use of juvenile convictions; ${ }^{207}$ and major differences in how many years into the past jurisdictions will consider registerable offenses. ${ }^{208}$ So challenging is the task that Texas has designated a particular agency with making registration eligibility determinations, requiring that agency to make available its accumulated wisdom of criteria and determinations, and has consolidated all registrant appeals in a single county court jurisdiction. ${ }^{209}$

The consequences of getting this legal analysis wrong are significant. Despite the fact that some state registration laws have been interpreted to contain no scienter requirement, ${ }^{210}$ prosecution at the felony level can result from a first offense. ${ }^{211}$ Moreover, failure-toregister convictions, even though predicated upon the nominally civil requirement of registration, can serve as a basis for future recidivismbased assessments and result in extended prison terms. ${ }^{212}$

In 1997, mindful of the variability of state registration laws and wishing to enhance registration coverage overall, Congress specified that states wishing to qualify for federal funds (1) require registrants

"like offense," requiring registration under Massachusetts law). Twenty years ago, Meir Dan-Cohen drew a distinction between "decision rules," addressed to judges and intended to guide decisions on the law's application, and "conduct rules," addressed to potential offenders. Meir Dan-Cohen, Decision Rules and Conduct Rules: On Acoustic Separation in Criminal Law, 97 HARV. L. REV. 625, 625-26 (1984). Dan-Cohen notes, however, that the respective rule types can be wedded in a single statute, $i d$. at 633-36, which would appear to be the case with recidivist and registration laws, because they at once speak to the judiciary and the lay public. But cf. Dru Stevenson, Toward a New Theory of Notice and Deterrence, 26 CARDOZO L. REV. 1535, 1542 (2004) (offering a defense of legal inscrutability more generally, based on the idea that laws "are addressed to the state itself, and not to the general public").

${ }^{206}$ See supra notes 135-40 and accompanying text.

${ }^{207}$ See supra note 134 and accompanying text.

${ }^{208}$ While many states use ten years as the cutoff, California extends back over sixty years and Missouri over twenty-five years. See CAL. Penal Code $\$ 290$ (a) (2) (D) (i) (West 1999 \& Supp 2005) (extending back to July 1, 1944); MO. ANN. STAT. § 589.400.1(1)-(5) (West 2003 \& Supp. 2005) (extending back to July 1, 1979).

${ }^{209}$ See supra notes 151-52 and accompanying text.

${ }^{210}$ See, e.g., State v. Young, 535 S.E.2d 380, 384 (N.C. Ct. App. 2000) (finding no scienter requirement in North Carolina law); State v. Cook, 700 N.E.2d 570, 583 (Ohio 1998) (finding no scienter requirement in Ohio law).

${ }^{211}$ See, e.g., ALASKA STAT. $\$ 11.56 .835$ (2004) (making failure-to-register a felony offense); ARIZ. REV. STAT. ANN. § 13-3824 (2001 \& Supp. 2005) (same).

${ }^{212}$ See People v. Carmony, 26 Cal. Rptr. 3d 365, 376-78 (Ct. App. 2005) (surveying state laws with regard to failure-to-register convictions and their effects on recidivismbased extended prison terms). 
to report any intended changes in state residence, (2) inform registrants of their duty to comply with registration requirements in their new state residence, and (3) notify the new state of residence of the registrant's anticipated move. ${ }^{213}$ To date, however, jurisdictions have been slow to take such steps, and constitutional challenges are only now surfacing in appellate courts.

In State v. Bryant, ${ }^{214}$ for instance, the Supreme Court of North Carolina addressed the due process claim of a carnival worker who, while subject to lifelong registration when living in South Carolina, failed to register in North Carolina when he decided to remain there while on tour. Neither North nor South Carolina, however, informed him that he was duty-bound to register in North Carolina upon his move. ${ }^{215}$ The Bryant court reversed a prior holding of the Court of Appeals that the North Carolina Legislature unconstitutionally failed to "adequately address the reality of our mobile society, in which people frequently move across state lines," ${ }^{216}$ and rejected application of Lambert v. California. ${ }^{217}$

According to the court, North Carolina's registration requirement materially differed from that invalidated in Lambert, which applied only in a municipality, not statewide, and targeted all convicted felons, not only sex offenders. ${ }^{218}$ Moreover, to the extent Lambert pertained, it applied only to conduct that is "wholly passive" and where no underlying circumstances existed "which might move one to inquire as to the necessity of registration." 219 The instant appeal, however, was "rich with circumstances" sufficient to put Bryant, when in South Carolina, on notice of the need to register in North Carolina:

21342 U.S.C. $\$ 14071$ (b) (1) (A) (iii), (b) (5) (2000). For an example of a state law to this effect, see WASH. REv. CODE ANN. § 9A.44.130(4) (a) (ix) (West Supp. 2005) ("Offenders required to register in Washington, who move to another state, ... shall register ... with the new state within ten days after establishing residence.").

${ }^{214} 614$ S.E.2d 479 (N.C. 2005).

${ }^{215}$ North Carolina law provided that notice of the state's registration requirement be given only to individuals prior to their release from its own prisons. N.C. GEN. STAT. $\$ 14-208.8$ (2003). For its part, South Carolina only required that a registrant provide written notice "within ten days of the change of address to a new state to the [South Carolina] county sheriff with whom the person last registered." S.C. CODE ANN. § 23-3-460 (Supp. 2004).

${ }^{216}$ State v. Bryant, 594 S.E.2d 202, 207 (N.C. Ct. App. 2004), rev'd, 614 S.E.2d 479 (N.C. 2005).

217355 U.S. 225 (1957). For discussion of Lambert, see supra note 106 and accompanying text.

${ }_{218}^{21}$ Bryant, 614 S.E.2d at 487.

${ }^{219}$ Id. at 488 (quoting Lambert, 355 U.S. at 228-29). 
First, defendant had actual notice of his lifelong duty to register with the State of South Carolina as a convicted sex offender. Second, defendant had actual notice that he must register as a convicted sex offender in South Carolina for "similar offenses from other jurisdictions" and had a duty to inform South Carolina officials of a move out of the state.... Third, defendant himself informed [South Carolina] law enforcement authorities that he had been convicted of a sex offense in Florida. ${ }^{220}$

These case-specific circumstances, the Bryant court held, coupled with the "pervasiveness" of the nation's sex offender registration laws, sufficed to "lead the reasonable individual to inquire of a duty to register in any state upon relocation." 221 Given the omnipresence of registration laws, the Bryant court reasoned, "it would be nonsensical to allow sex offenders to escape their duty to register by moving to another state that has not provided them with actual notice of their duty to register, and then claim ignorance of the law." ${ }^{222}$

The Ohio Court of Appeals reached a similar result in State v. Beckley, ${ }^{223}$ where both Ohio and Washington failed to notify a former Washington resident of the need to register in Ohio upon his arrival there. Distinguishing Lambert, the court also held that it would be "nonsensical to find that a sex offender could escape his reporting requirements by moving to Ohio, a state that does not have notice requirements for out-of-state sex offenders, and then claim ignorance or no notice." ${ }^{224}$ The court added:

If a sex offender moves from a state in which he has been required to register, it is logical and imperative that the offender inquire into the registration laws of the new state. A sex offender should not escape criminal responsibility when he violates one state's laws of registration and then claim ignorance of another state's laws. The classification of a sex offender does not disappear when the offender crosses state lines. All fifty states have enacted sex offender registration laws in varying degrees in compliance with [federal mandates].

Whatever the outcomes of future challenges, and regardless of state efforts to inform immigrant offenders of the need to register, no-

${ }^{220} I d$.

${ }^{221} I d$.

${ }^{222}$ Id.; see also People v. Patterson, 708 N.Y.S.2d 815, 826 n.5 (Crim. Ct. 2001) (distinguishing Lambert on the rationale that, unlike the municipal law condemned there, modern registration laws are enacted by states and are in effect nationwide).

${ }^{223}$ No. 83254, 2004 WL 1277358 (Ohio Ct. App. June 10, 2004), appeal denied, 816 N.E.2d 1080 (Ohio 2004), cert. denied, 125 S. Ct. 2548 (2005).

${ }^{224} I d$. at $* 3$.

${ }^{225}$ Id. at $* 4$. 
tice concerns will persist. ${ }^{226}$ This is because even when general notice of the registration requirement is given, whether by registrants' former or future states of residence, ${ }^{227}$ registrants (and law enforcement in the new state) are still faced with a complex interpretive legal task. Even more problematic, under the internal approach, individuals not previously required to register in a foreign state might, unbeknownst to them, be required to do so in their newly adopted state. Finally, exacerbating the foregoing, courts will be inclined to deem registration failures as a mistake of law, not likely warranting a defense in prosecutions. ${ }^{228}$

Similar challenges are faced by individuals convicted of a felony in their newly adopted state, who face the specter of enhancement on the basis of a prior foreign state conviction. To be sure, the consequences are less immediate with recidivism, inasmuch as the interjurisdictional analysis is triggered only upon conviction for a new felony, not a mere change of domicile as with registration. However, as notice is a prerequisite to the fair enforcement of the criminal law generally, so too should notice apply to application of sentence enhancements triggered by violations of the underlying substantive criminal law. If a crime classified as a misdemeanor in a foreign state can be treated by the forum as a felony for purposes of assessing recidivism, ${ }^{229}$ or the foreign state would not count deferred or probated adjudications, ${ }^{230}$ or a nolo contendere plea, ${ }^{231}$ or a prior juvenile disposition, ${ }^{232}$ notice is implicated. ${ }^{233}$ Moreover, to the extent that recidi-

${ }^{226}$ For a rare instance of a successful notice-based claim, see State $v$. Tippett, 624 N.W.2d 176, 178 (Iowa 2001) (reversing the conviction of a former Illinois registrant prosecuted for failure to register in Iowa).

${ }^{227}$ The authority of one state to impose a registration requirement on another itself presents an intriguing question of extraterritorial authority, which to date has failed to raise judicial concern. See People v. Smith, 86 P.3d 348, 354 (Cal. 2004) (upholding the authority of California to impose a reporting duty on registrants wishing to leave the state and likening the requirement to a preexisting tax or child support obligation); State v. Wigglesworth, 63 P.3d 1185, 1190 (Or. Ct. App. 2003) (holding that the Oregon reporting requirement and its violation were "triggered by defendant's action in Oregon and, as such, had no extraterritorial effect”).

${ }^{228}$ See, e.g., People v. Baker, No. C039458, 2003 WL 22422414, at*4 (Cal. Ct. App. Oct. 24, 2003) (holding that a registrant's "belief regarding his legal status was a mistake of law," not a justifying defense). See generally JOSHUA DRESSLER, UNDERSTANDING CRIMINAL LAW $\S \S 13.01-.03$, at 165-77 (3d ed. 2001) (discussing mistakes of law).

${ }^{229}$ See supra notes 73-77 and accompanying text.

${ }^{230}$ See supra note 83 and accompanying text.

231 See supra notes 84-85 and accompanying text.

${ }^{232}$ See supra notes 89-91 and accompanying text. 
vism-based enhancements are predicated on deterrence and recidivists calculate the risks, costs, and benefits of committing a new crime ${ }^{234}$ practical concern should arise over the uncertain quality of internal approach laws. ${ }^{235}$ Finally, such uncertainty inevitably influences plea bargains, as the leverage of prosecutors is enhanced. ${ }^{236}$

${ }^{233}$ Emblematic of this concern, states typically require that the prosecution give advance notice of its intent to use a prior foreign conviction for enhancement. See, e.g., MONT. CODE ANN. § 46-13-108 (2003) ("[I]f the prosecution seeks treatment of the accused as a persistent felony offender, notice of that fact must be given ....”); N.H. Rev. STAT. ANN. § 651:6(III) (LexisNexis Supp. 2004) ("[I]f notice . . is given the defendant prior to the commencement of trial, a defendant may be sentenced to an extended term of imprisonment."); cf. Small v. United States, 125 S. Ct. 1752, 1753 (2005) (rejecting consideration of a prior foreign nation conviction because, inter alia, "it would leave those previously convicted in a foreign court ... uncertain about their legal obligations").

${ }^{234}$ See, e.g., N.Y. PENAL LAW $\$ 1.05(6)$ (McKinney 1998) (identifying as a goal of recidivist enhancement "insur[ing] the public safety by preventing the commission of offenses through the deterrent influence of the sentences authorized"). As Paul Robinson has observed, notice at once implicates due process and deterrence concerns:

A central function of the criminal law is to publicly announce what the criminal law commands, both what it prohibits and what it requires. The function is central for two reasons. First, people must know the rules if the deterrence threat of the sanction is to have an effect: The law cannot deter people from engaging in conduct that they do not know it prohibits, or compel people to engage in conduct that they do not know it requires. Second, notions of fairness require that a person have a fair opportunity to know the law's commands before being punished for failing to obey them.

Paul H. Robinson, Are Criminal Codes Irrelevant?, 68 S. CAL. L. REV. 159, 163 (1994).

${ }^{235}$ See United States v. Wilson, 159 F.3d 280, 295 (7th Cir. 1998) (Posner, C.J., dissenting) (decrying the lack of notice to those subject to a federal firearms ban, and concluding that when a law is not patent, it is "not a deterrent. It is a trap"). Moreover, while perhaps rare, the uncertainty noted might discourage migration and thus socially and economically advantageous activities. For instance, writing with respect to the uncertainties of the Racketeer Influenced and Corrupt Organizations Act, one author commented:

Neither the RICO statute nor its judicial interpretations provide equivalent clarity or specificity. In this respect, uncertainty also imposes costs. In many cases, when the outcome is uncertain, a prudent defendant may assume the worst and proceed from there. This creates an incentive to avoid risky situations through extra investigation and settlement expenditures.

Michael A. DiMedio, A Deterrence Theory Analysis of Corporate RICO Liability for "Fraud in the Sale of Securities," 1 GEO. MASON L. REV. 135, 158-59 (1994); see also Richard Craswell \& John E. Calfee, Deterrence and Uncertain Legal Standards, 2 J.L. ECON. \& ORG. 279, 29899 (1986) (noting that legal uncertainty can lead to undue risk aversion and thus suboptimal social gain).

${ }^{236}$ See Bordenkircher v. Hayes, 434 U.S. 357, 364-65 (1978) (upholding the authority of a prosecutor to threaten pursuit of recidivist enhancement if a defendant refuses to plead guilty to the initial charge); see also Blakely v. Washington, $124 \mathrm{~S}$. Ct. 2531, 2542 (2004) (noting that there is "no shortage of in terrorem tools at prosecutors' disposal”); Lynn N. Hughes, Don't Make a Federal Case Out of It: The Constitution and the 
This informational deficit, in turn, is not likely remedied by judicial involvement, given that courts undertake a highly particularized, caseby-case, post-hoc analysis unlikely to be of much utility to immigrating offenders. ${ }^{237}$

\section{Unequal Treatment}

Even assuming that registrants and recidivists are able to accurately assess the impact of the applicable laws in their newly adopted states, the laws themselves threaten unequal treatment. The effect is especially pronounced with the external approach. When forum states defer to outcomes reached in foreign states with significant variations in substantive laws, punishments, and procedural rights, otherwise similarly situated individuals can be treated unequally. ${ }^{23}$

With respect to registration, the notable idiosyncrasies of state laws are permitted to affect outcomes in other states. For instance, if an individual moves from South Carolina to one of the fifteen other states using an external test for registration, the Palmetto State's unusually broad gamut of registerable offenses will come into play (including, for example, peeping, voyeurism, and buggery). ${ }^{239}$ Similar scenarios arise if one moves to an external state after having been convicted of obscenity or second degree prostitution (involving adults) in Alabama; ${ }^{240}$ adultery in Kansas; ${ }^{241}$ bestiality in South Dakota; ${ }^{242}$ a "crime against nature" in Idaho and Louisiana; ${ }^{243}$ or consen-

Nationalization of Crime, 25 AM. J. CRIM. L. 151, 161 (1997) (containing the observation of a U.S. district judge urging that " $[\mathrm{w}] \mathrm{e}$ need to limit the range and number of laws a prosecutor has to use").

${ }^{237}$ Nor are the judicial efforts likely to be of much use to the jurisprudence of either the foreign state or the forum, given that the former is not obliged to take note of the construction, and the latter typically has little ongoing need for the construction of another state's laws. In Erie situations, on the other hand, states benefit from federal court interpretations of state laws and constitutions. See Barry Friedman, Under the Law of Federal Jurisdiction: Allocating Cases Between Federal and State Courts, 104 Colum. L. REV. 1211, 1237-41 (2004) (surveying scholarship on "cross-fertilization”).

${ }^{238}$ In such circumstances, there arises another parallel with Erie Railroad Co. $v$. Tompkins, 304 U.S. 64 (1938). While the Erie doctrine was motivated out of uniformity concerns, see supra notes 172-73, it, like the state-state use of the external approach, has resulted in unequal outcomes. See Michael H. Gottesman, Draining the Dismal Swamp: The Case for Federal Choice of Law Statutes, 80 GEO. L.J. 1, 10-11 (1991) (noting that Erie replaced vertical forum-shopping concerns with horizontal forum-shopping concerns).

2392005 S.C. Acts 141 (amending S.C. CODE ANN. § 23-3-430(C) (10), (12), (14), (17), (18) (Supp. 2004)).

2402005 Ala. Laws 301 (amending ALA. CODE $§ 13 A-11-200$ (1994)).

${ }^{241}$ KAN. STAT. § 22-4902(a) (5) (A) (2003).

${ }^{242}$ S.D. CODIFIED LAws $\$ \S 22-22-30(14)$, 22-22-31 (Supp. 2005). 
sual sex between minors in Connecticut. ${ }^{244}$ A conviction for possessing child pornography can have a similar effect in many states, ${ }^{245}$ as can one for indecent exposure, ${ }^{246}$ despite judicial concerns expressed over the requirement. ${ }^{247}$ Some states require registration for nonsexual offenses, for example, involuntary manslaughter (Kansas) ${ }^{248}$ or robbery, homicide, and aggravated assault (Montana), ${ }^{249}$ and do not limit registerable offenses to felonies. ${ }^{250}$ Finally, most but not all states require juveniles to register ${ }^{251}$ and can vary significantly in the length of time during which registration is required. ${ }^{2.2}$

Under such circumstances, the external approach results in two possible kinds of unequal treatment. The first involves immigrants from states with narrower registration eligibility criteria; they, unlike the immigrant from, say, South Carolina, will not be subject to registration because it was not required by the foreign state from which they migrated. The second arises when an offender in the forum state is not required to register as a result of being convicted of an offense (e.g., peeping), yet the newcomer is so required, again because of the idiosyncratic nature of the foreign state's registration law. Alternatively, the duration of registration can be made lengthier for newcomers if the forum state ties the newcomer's period of registration to the

243 IDAHO CODE ANN. § 18-8304(a) (Supp. 2005); LA. REV. STAT. ANN. §§ 15:541(14.1), :542 (2005).

${ }^{244}$ CONN. Gen. STAT. ANN. $§ \S 54-250(2)$ (A), -250(5), -251 (a) (West Supp. 2005).

${ }^{245}$ See, e.g., ALASKa STAT. $\$ \S 11.61 .127,12.63 .010,12.63 .100(6)(\mathrm{C})(\mathrm{v})$ (2004) (including possession of child pornography as a registerable offense); MO. ANN. STAT. $\S$ $589.400(1)-(2)$ (West Supp. 2005) (same); S.D. CODIFIED LAWS $§ \S 22-22-30(5), 22-22-$ 31 (Supp. 2005) (same).

${ }^{246}$ See, e.g., 2005 N.D. Laws 121 (amending N.D. CENT. CODE $\$ § 12.1-20-12.1$, 12.132-15(1)(e) (1997 \& Supp. 2005)) (defining indecent exposure as a class A misdemeanor and requiring registration); 2005 S.C. Acts 141 (amending S.C. CODE ANN. § 23-3-430(C)(14) (Supp. 2004) (including indecent exposure as a registerable offense)).

${ }^{247}$ See State v. Chun, 76 P.3d 935, 939-40 (Haw. 2003) (questioning the propriety of using indecent exposure as a registration predicate); see also CAL. PENAL CODE $\S$ 290 (a) (2) (D) (iii), (iv) (West $1999 \&$ Supp. 2005) (adopting an external approach to registration, but expressly excluding indecent exposure).

${ }^{248}$ KAN. STAT. ANN. \$ 22-4902(a) (2), (d) (5) (2003).

2492005 Mont. Laws ch. 313 (amending MONT. CODE ANN. §§ 45-5-102, -202, -401, 46-23-502(9) (a) (2003)).

${ }_{251}^{250}$ See supra note 133 and accompanying text.

${ }^{251}$ See supra note 134 and accompanying text.

${ }^{252}$ Compare, e.g., CAL. PenAl CODE $\$ 290$ (a) (1)(A) (West 1999 \& Supp. 2005) (requiring lifetime registration), with 42 PA. CONS. STAT. ANN. § 9795.1(a) (West Supp. 2005) (requiring that non-aggravated offenders register for ten years). 
duration imposed by the state left behind. ${ }^{253}$ In each such situation, registration, with its direct ${ }^{254}$ and collateral burdens (including possibly community notification, with its litany of negative consequences) ${ }^{255}$ is driven by the geographic happenstance of where the foreign conviction occurred, leading to unequal outcomes in the forum state. ${ }^{256}$

Similar effects can occur with recidivist laws. For instance, New York law, characterized by an internal approach, contains the unusual provision that prior foreign convictions be evaluated for recidivist eligibility in terms of the sentence authorized in New York at the time of the subsequent crime, whereas prior New York convictions are assessed in terms of the time of the prior conviction. ${ }^{257}$ As a result, prior foreign convictions, unlike domestic ones, can possibly benefit from a "downgrade." 258 On the other hand, Alaska mandates sentence enhancement for persons convicted elsewhere of a lewd and lascivious

${ }^{253}$ Under Pennsylvania law, for instance, an immmigrating ex-offender previously subject to community notification in another state remains subject to registration for the durational extent the other state requires, or ten years (Pennsylvania's duration), whichever is greater. 42 PA. CONS. STAT. ANN. § 9795.2(b) (4) (v) (West Supp. 2005). As a result, an individual moving to Pennsylvania from one of the many states reflexively imposing notification on all registrants, and imposing lifetime registration, will experience a significantly extended period of registration (and notification) compared to an indigenous Pennsylvanian. See, e.g., FLA. Stat. ANN. § 943.0435 (West Supp. 2005) (subjecting all registrants to notification and requiring them to maintain registration for life).

${ }^{254}$ Such effects include, inter alia, significant variations in duration of registration, the intervals at which registration information must be updated and the means by which it must occur, prohibitions of name changes, and the requirement that personal identification cards be carried. See Logan, supra note 165, at 183-86 (surveying a variety of direct effects of registration requirements). To this list of burdens can be added strict limits on where registrants can live. See, e.g., Doe v. Miller, 405 F.3d 700, 723 (8th Cir. 2005) (upholding against constitutional challenges an Iowa law that prohibits registrants from living within 2000 feet of a school or child care facility).

${ }^{255}$ See Logan, supra note 165, at 182-207 (noting the many significant collateral consequences of registration and notification, including stigma and limited housing and employment opportunities).

${ }^{256}$ Hendrix v. Taylor, 579 S.E.2d 320 (S.C. 2003), provides a variation on this scenario. There an immigrant with a Colorado conviction was required under South Carolina law to register annually for life, even though Colorado would possibly allow registration to cease in five years. $I d$. at 322,325 .

${ }^{257}$ See People v. Walker, 623 N.E.2d 1, 4 (N.Y. 1993) (interpreting New York's penal code defining a second felony offender).

${ }^{258}$ People v. Pacheco, 426 N.Y.S.2d 57, 61 (App. Div. 1980), aff'd, 421 N.E.2d 114 (N.Y. 1981). According to the court, "[t] he statute concededly works a harsher result on those with a prior New York felony conviction," but the distinction is justified by a proper legislative desire "to be more severe with those who have consistently violated the laws of this State." Id. 
act upon a child, yet refuses to enhance sentences based on prior similar in-state convictions. ${ }^{259}$

More commonly, disparity arises with the external approach. In states using this approach, decisions by foreign jurisdictions to punish an offense at the felony level can compel that the conviction be counted in assessing recidivism in the forum state, even when the offense would not be punished as harshly (and trigger recidivist status) in the forum. ${ }^{260}$ Variations in the treatment of juveniles and pleas of nolo contendere can also lead to unequal treatment when a state defers to another state's use of such dispositions, yet does not do so with respect to its indigenous offenders. ${ }^{261}$

Finally, with both registration and recidivist enhancement laws, varied procedural rules and rights among states come to have extraterritorial significance. Variations with respect to such matters as the requirement of indictment, ${ }^{262}$ jury size and unanimity, ${ }^{263}$ and even application of the Fourth Amendment's exclusionary rule, ${ }^{264}$ can influence underlying outcomes and hence impact the criminal histories of individuals who migrate. Again, disparity can arise in at least two distinct respects: first, among individuals who migrate from foreign states with varied protections, and as a result potentially bring different outcomes; second, when the forum state defers to the disposition of the foreign state, yet would provide more protection to its indigenous criminal defendants.

259 See AlASKA STAT. \$ 12.55.145(a) (4) (B) (2004) (“[A] felony conviction in another jurisdiction making it a crime to commit any lewd and lascivious act upon a child ... is a prior conviction for sexual felony."). The provision was prompted by a judicial decision refusing to count a defendant's prior California conviction for lewd and lascivious conduct, because that California law swept more broadly than the analogous Alaska law. Scroggins v. State, 951 P.2d 442, 444 (Alaska. Ct. App. 1998).

${ }^{260}$ See supra note 93 and accompanying text.

261 See, e.g., State v. Vizcaino-Roque, 800 S.W.2d 22, 23 (Mo. Ct. App. 1990) (counting a prior Florida nolo contendere-based conviction that would not be recognized in Missouri).

${ }^{262}$ See Bryan H. Wildenthal, The Road to Twining: Reassessing the Disincorporation of the Bill of Rights, 61 OHIO ST. L.J. 1457, 1476-77 (2000) (discussing the decreasing use of grand juries).

${ }^{263}$ See Robert H. Miller, Comment, Six of One Is Not a Dozen of the Other: A Reexamination of Williams v. Florida and the Size of State Criminal Juries, 146 U. PA. L. REV. 621, 625-31 \& n.42 (1998) (discussing the increasing use of petit juries comprised of fewer than twelve jurors and experimentation with non-unanimous juries).

${ }^{264}$ Compare, e.g., State v. Duntz, 613 A.2d 224, 228 (Conn. 1992) (rejecting the "good faith" exception to the exclusionary rule), with Crayton v. Commonwealth, 846 S.W.2d 684, 688-89 (Ky. 1992) (embracing the "good faith" exception). 
Under each of the foregoing scenarios, while as a technical matter the individual is not being "punished" again, ${ }^{265}$ the effect can be the same. With registration and recidivist laws, the decisions of a foreign state function to regulate and affect the liberty of ex-residents as they migrate elsewhere. ${ }^{266}$ A residual legal world is thus created with outcomes, sometimes quite unfairly, turning on the legal regime of the jurisdiction the individual has left behind. ${ }^{267}$

\section{Replication and the "Frozen-in-Amber" Effect}

In addition to its significant institutional and personal effects, interconnection has broad societal consequences. In particular, the use by states of one another's prior criminal convictions can serve to replicate temporally and geographically contingent aspects of substantive criminal law, punishment, and procedure.

Temporal contingency is most evident with respect to the substantive law, which, in tandem with prosecutorial priorities, typically reflects the public sentiment of its time of origin and application. As a

${ }^{265}$ See Smith v. Doe, 538 U.S. 84, 105-06 (2003) (holding that registration and community notification do not qualify as punishment and thus do not violate the Ex Post Facto Clause); Witte v. United States, 515 U.S. 389, 400 (1995) (noting that a recidivism-based enhancement is not an additional punishment for a prior conviction but rather "a stiffened penalty for the latest crime, which is considered to be an aggravated offense because a repetitive one”); cf. Kansas v. Hendricks, 521 U.S. 346, 362 (1997) (condoning the use of a prior criminal conviction as an evidentiary basis to justify involuntary civil commitment of "sexually violent predators").

${ }^{266}$ For discussion of the propriety of extraterritorial regulation more generally, in the face of the traditional position rejecting it, see Seth F. Kreimer, The Law of Choice and Choice of Law: Abortion, the Right to Travel, and Extraterritorial Regulation in American Federalism, 67 N.Y.U. L. REV. 451 (1992) (discussing and endorsing the traditional view that states should not punish their citizens for conduct that occurred in other states where such conduct is condoned); Mark D. Rosen, Extraterritoriality and Political Heterogeneity in American Federalism, 150 U. PA. L. REv. 855 (2002) (advocating a state's authority to regulate the out-of-state behavior of its citizens, in order to avoid the prospect of "travel-evasion").

${ }^{267}$ This of course is not to say that intrastate disparities do not result in unequal treatment vis-à-vis indigenous defendants. See, e.g., Joshua Bowers, Comment, "The Integrity of the Game Is Everything": The Problem of Geographic Disparity in Three Strikes, 76 N.Y.U. L. REV. 1164, 1172-80 (2001) (discussing inconsistencies in the application of California's "three strikes" recidivist law); Ashley Rupp, Comment, Death Penalty Prosecutorial Charging Decisions and County Budgetary Restrictions: Is the Death Penalty Arbitrarily Applied Based on County Funding?, 71 FORDHAM L. REV. 2735, 2752-67 (2003) (discussing inconsistent applications of the death penalty within states due to budgeting constraints). 
consequence, criminal laws are subject to "intergenerational drift,"268 which the static, retrospective methodology typical of registration and recidivism fails to accommodate. ${ }^{269}$ Convictions for offenses once defined differently, ${ }^{270}$ which are no longer applied or are repealed, ${ }^{271}$ or which themselves perhaps reflect discriminatory effects (e.g., racial discrimination $^{272}$ or homophobia ${ }^{273}$ ), can be preserved and given contemporary force. ${ }^{274}$

${ }^{268}$ Harry V. Ball \& Lawrence M. Friedman, The Use of Criminal Sanctions in the Enforcement of Economic Legislation: A Sociological View, 17 STAN. L. REV. 197, 221 (1965). As Susan Pilcher more recently noted:

Public perception of the magnitude of any given social harm is likely to shift over time in response to the changing social context. Conduct that is regarded as morally neutral at one time ... at a later date may come to be regarded as wrongful and deserving of community condemnation. Similarly, conduct that is considered blameworthy today may easily be seen as "innocent" in a more permissive era.

Susan L. Pilcher, Ignorance, Discretion and the Fairness of Notice: Confronting "Apparent Innocence” in the Criminal Law, 33 AM. CRIM. L. REV. 1, 35-36 (1995).

${ }^{269}$ Of course, the criminal law itself is not static; on the contrary, it is constantly being added to (but rarely subtracted from). Rather, the point is that interconnection gives old laws new life.

${ }^{270}$ See, e.g., State v. Brown, 636 S.W.2d 929, 936 (Mo. 1982) (counting a prior statutory rape conviction involving a fifteen-year-old victim, notwithstanding a statutory change taking effect two months later revising the age to "less than fourteen"), overruled on other grounds by State v. Jones, 716 S.W.2d 799 (Mo. 1986); State v. Sandoval, 89 P.3d 92, 94 (N.M. Ct. App. 2004) (counting a prior criminal trespass conviction that lacked the "knowing" element, notwithstanding that the element was subsequently added by the legislature); State v. Frederick, 674 P.2d 136, 142-43 (Wash. 1983) (counting a prior grand larceny conviction, notwithstanding a statutory change that increased the value element triggering felony status), overruled on other grounds by Thompson v. State Dep't of Licensing, 982 P.2d 601 (Wash. 1999). But see Lee v. State, 673 P.2d 892, 894 (Alaska Ct. App. 1983) (rejecting a prior grand larceny conviction based on a subsequent statutory change in the qualifying amount).

${ }^{271}$ See William J. Stuntz, Substance, Process, and the Civil-Criminal Line, 7 J. ConTEMP. LEGAL ISSUES 1, 34-37 (1996) (discussing a variety of criminal laws that are no longer enforced).

272 See generally CORAMAE Richey MANN, UnEQUAL JUSTICE: A QUESTION OF COLOR 115-18 (1993) (noting historic and contemporary laws targeting particular minority groups); RANDALL KENNEDY, RACE, CRIME AND THE LAW 84-85 (1997) (discussing postCivil War "Black Codes" permitting African-Americans to be singled out for prosecution).

${ }^{273}$ See generally William N. Eskridge, Jr., Law and the Construction of the Closet: American Regulation of Same-Sex Intimacy, 1880-1946, 82 IOWA L. REV. 1007, 1068-69 (1997) (discussing biased enforcement of criminal laws against non-heterosexuals); Robert L. Jacobson, Note, "Megan's Laws" Reinforcing Old Patterns of Anti-Gay Police Harassment, 87 GEO. L.J. 2431, 2449-50 (1999) (discussing unequal enforcement of criminal laws against homosexual men).

${ }^{274}$ See infra note 373 and accompanying text (noting that before Lawrence $v$. Texas, 539 U.S. 558 (2003), invalidated laws criminalizing consensual adult sodomy, such con- 
Similarly, because analysis usually focuses on the punishment imposed at the time of the former conviction, the laws can resist progressive change in sentencing mores, replicating especially punitive times in the nation's history. This is especially the case with recidivist enhancements. ${ }^{275}$ Although many states are now re-thinking the draconian sentences imposed in past decades, ${ }^{276}$ the retrograde mien of recidivist laws functions to perpetuate past harshness and give it contemporary effect. ${ }^{277}$

victions would be exported and incorporated by registration laws); see also Lawrence, 539 U.S. at 579 ( "[L] aws once thought necessary and proper [can] in fact serve only to oppress.").

${ }_{275}$ See, e.g., Elston v. State, 687 So. 2d 1239, 1241 (Ala. Crim. App. 1996) (holding that a prior out-of-state conviction need only have been a felony as defined by Alabama law at the time of its adjudication); State v. Brooks, 968 S.W.2d 312, 313-14 (Tenn. Crim. App. 1997) (comparing Virginia and Tennessee laws from the time of the defendant's prior conviction, not as they exist at the time of enhancement); State v. Serr, 664 P.2d 1301, 1303 (Wash. Ct. App. 1983) (holding that prior convictions must have been felonies at the time of perpetration); see also Maier v. State, 437 N.E.2d 448, 453 (Ind. 1982) (noting that the defendant was not entitled to have the jury instructed that a prior conviction, although a felony offense at the time of conviction, had been reduced to a misdemeanor in the interim). This ossification effect, it bears mention, is not unique to interstate recidivist analysis. See, e.g., State v. King, 336 N.W.2d 576, 580 (Neb. 1983) (counting a prior Nebraska felony conviction for operating a motor vehicle to avoid arrest notwithstanding the later statutory reduction of the crime to a misdemeanor).

${ }^{276}$ Among the most notable examples is New York's decision to mitigate its draconian "Rockefeller drug laws." See Joe Mahoney \& Tracy Connor, State KOs Toughest Drug Laws, N.Y. DAILY NEWS, Dec. 8, 2004, at 4 (noting that although the laws have not been repealed, mandatory fifteen-years-to-life sentences have been cut to eight years); see also Fox Butterfield, States Ease Laws on Time in Prison, N.Y. Times, Sept. 2, 2001, at 1A (noting that fiscal pressures have prompted several states to modify draconian sentencing laws). For a discussion of harsh criminal law-related measures enacted in recent years, see Wayne A. Logan, "Democratic Despotism" and Constitutional Constraint: An Empirical Analysis of Ex Post Facto Claims in State Courts, 12 WM. \& MARY BILl RTS. J. 439, 468-75 (2003). For an overview of the shifting tides of penal theory and sentencing policy more generally, see Michael Tonry, Obsolescence and Immanence in Penal Theory and Policy, 105 COLUM. L. REV. 1233 (2005).

${ }^{277}$ This effect is especially pronounced in jurisdictions that focus on the extent to which a prior offense was "punishable," focusing not on the actual sentence imposed or actually served, but rather on what the legislature authorized. See, e.g., Welch v. State, 828 N.E.2d 433, 439 n.5 (Ind. Ct. App. 2005) (observing that the term served was less important than the "term for which the convicted person might have been imprisoned"). Such a focus ignores individualized judicial determinations in actual cases warranting mitigation and fails to accommodate the common tendency of legislatures to set punishments at an extreme, with the expectation that judges will rarely reify the political position with actual imposed liberty deprivations. See Ewing v. California, 538 U.S. 11, 43 (2003) (Breyer, J., dissenting) ("Sentencing statutes often shed little light upon real prison time... [T] he statutory maximum is rarely the sentence imposed, and the sentence imposed is rarely the sentence that is served." (citations omitted)). 
Geography comes into play because of the many regional and state-level differences at work, which the static methodology of registration and recidivist laws replicates. States, of course, vary considerably with respect to the behaviors they deem worthy of criminal condemnation ${ }^{278}$ and the punishments they impose, ${ }^{279}$ with race playing a distinct and geographically varied role. ${ }^{280}$ Considerable variation also exists with procedural practices. While courts disregard foreign convictions secured without affording defendants constitutional rights (for example, failing to obtain valid waivers for guilty pleas), ${ }^{281}$ they regularly tolerate a broad array of less rights-protective procedures that are not of constitutional magnitude. ${ }^{282}$ As a result, rather than remaining cabined in their respective states of origin, perhaps less than optimal procedural standards may be replicated across the land.

\section{E. The Prospects for Amelioration}

Despite the foregoing concerns, it is unlikely that states will take ameliorative measures any time soon. Such change is especially improbable as a result of the political process. The political impotence of criminal offenders as a whole, amply demonstrated in the public choice literature ${ }^{283}$ is apt to be particularly pronounced among immi-

278 See supra note 10 and accompanying text.

279 See supra note 13 and accompanying text.

280 See, e.g., Daniel M. Filler, Silence and the Racial Dimension of Megan's Law, 89 IOWA L. REV. 1535, 1538 (2004) (noting that African Americans are more than sixteen times as likely to be subject to registration and community notification than whites, and discussing significant variations among states). For more on the racially disparate effect of sentencing more generally, see DAVID COLE, NO EQUAL JUSTICE: RACE AND CLASS IN THE AmERICAN CRIMINAL Justice System (1999); Symposium, The New Data: OverRepresentation of Minorities in the Criminal Justice System, 66 LAW \& CONTEMP. PROBS. 1 (2003).

281 See, e.g., People v. Bradley, 324 N.W.2d 499, 502 (Mich. Ct. App. 1982) (finding a defendant's prior guilty pleas invalid and stating that " $[\mathrm{w}]$ hile we certainly cannot reverse the Indiana convictions, we will not permit the prior convictions to lengthen the defendant's imprisonment for his present felony conviction [in Michigan]"); see also United States v. Tucker, 404 U.S. 443, 449 (1972) (holding that the Sixth Amendment prohibits the use of a prior conviction to enhance a sentence if the conviction was obtained in violation of the right to counsel).

${ }^{282}$ See, e.g., People v. Johnson, 285 Cal. Rptr. 394, 399 (Ct. App. 1991) (counting a prior Nevada conviction toward sentence enhancement even though it was secured without the same procedural protections that California would afford).

283 As Harold Krent has written, "[l] egislators need not fear that enacting most criminal measures will dry up campaign coffers. Throughout history, criminal offenders have been from the poorest strata in society . . . . Nor will legislators necessarily lose votes if they are insensitive to the needs of convicted felons." Harold J. Krent, The Puzzling Boundary Between Criminal and Civil Retroactive Lawmaking, 84 GEO. L.J. 2143, 2168- 
grant ex-offenders, and sex offenders in particular, ${ }^{284}$ whose newcomer status makes them even less capable of influencing political change. ${ }^{285}$

Nor are the courts likely to hold much promise for redress based on any potential constitutional challenges. As for equal protection, the Supreme Court, consistent with its view that interstate disparities must only satisfy rational basis review, ${ }^{286}$ has twice upheld West Virginia's recidivist law that allows enhanced sentences for those previously convicted of a crime punishable by "confinement in a penitentiary." ${ }^{287}$ As New York's highest court concluded in rejecting an equal protection challenge (against its erstwhile external recidivist law):

[Such enhancements are] rationally related to the valid governmental aim of treating habitual offenders more severely than first time offenders .... While persons guilty of acts which are felonies in other jurisdictions[,] but not in New York, are treated as second felony offenders, the statutory classification does not result in treatment so disparate as to be arbitrary or invidiously discriminatory ....

69 (1996); see also Logan, Democratic Despotism, supra note 276, at 468, 495 (surveying extensive public choice commentary addressing the political impotence of criminal offenders).

${ }^{284}$ See Eric S. Janus \& Wayne A. Logan, Substantive Due Process and the Involuntary Confinement of Sexually Violent Predators, 35 CONN. L. REV. 319, 320-21 (2003) (discussing the widespread disdain felt for sex offenders and their attendant political powerlessness).

${ }^{285}$ Short of lobbying as such, voting itself is in question: even those immigrant exoffenders who wish to vote might be barred as a result of their prior felony convictions. See Angela Behrens, Note, Voting-Not Quite a Fundamental Right? A Look at Legal and Legislative Challenges to Felon Disenfranchisement Laws, 89 MINN. L. REV. 231, 239 n.55 (2004) (noting that fourteen states permanently bar persons convicted of felonies from voting); cf. Paul Tiao, Student Article, Non-Citizen Suffrage: An Argument Based on the Voting Rights Act and Related Law, 25 Colum. Hum. RTS. L. REV. 171, 171-72 (1993) (noting that legal permanent residents are not allowed to vote and thus are unable to voice their political opinions at the polls). An interesting, and seemingly as yet unaddressed question, thus looms: can a conviction in a foreign state serve to permanently disenfranchise an ex-felon who moves to a state with a more lenient view on suffrage, or, vice versa, a less lenient one? Precedent exists for the proposition that one state need not honor another's decision to restore the civil rights of a convicted felon, permitting the felon to be prosecuted for illegal possession of a firearm. See Farnsworth v. Commonwealth, 599 S.E.2d 482, 484 (Va. Ct. App. 2004) (permitting the use of a prior West Virginia conviction as a predicate felony even though the defendant's civil rights had been restored in West Virginia).

${ }^{286}$ See, e.g., Martinez v. Bynum, 461 U.S. 321, 328 n.7 (1983) (applying a rational basis test to state citizenship criteria).

${ }^{287}$ Oyler v. Boles, 368 U.S. 448, 449 (1962); Graham v. West Virginia, 224 U.S. 616, 631 (1912). Of note, West Virginia itself has since conceived of its recidivist enhancement provision as being of an internal nature. See supra note 54. 
The Legislature . . . exercised its considered judgment to provide that the seriousness of a crime should be determined by the severity of the sentence and the norms prevailing in the jurisdiction in which a crime was committed. There is no warrant for any alarm in what may be termed as exaggerated fears of frivolous or perverse sister-State punishment. The possible disparity of treatment between prior New York offenders vis-à-vis prior out-of-State offenders does not vitiate the legislative decision that an individual who has previously elected to violate the criminal standards of the society in which he was found should be treated as an habitual offender. ${ }^{288}$

On the other hand, equal protection claims challenging the differential use of registration, and more specifically community notification, have of late shown some potential for success. While courts have uniformly upheld state decisions to single out those convicted of sex offenses for registration and notification, ${ }^{289}$ and even to target solely those convicted of particular sex offenses, ${ }^{290}$ federal district courts-in Pennsylvania at least-have been troubled by the Commonwealth's disparate treatment of in- versus out-of-state registrants. In Doe v. McVey ${ }^{291}$ and Lines v. Wargo, ${ }^{292}$ the Eastern and Western Districts, respectively, enjoined application of a Pennsylvania law that allowed indigenous sex offenders to contest their eligibility for community notification, and afforded them due process protections (including right to counsel and a hearing), yet withheld such rights from immigrant registrants and automatically subjected them to registration and notification. ${ }^{293}$

${ }^{288}$ People v. Parker, 359 N.E.2d 348, 350-51 (N.Y. 1976); cf. Marshall v. United States, 414 U.S. 417, 430 (1974) (rejecting an equal protection challenge against a federal law denying rehabilitative treatment and imposing a prison term on persons twice convicted of felonies, as classified by the offense situs).

${ }^{289}$ See, e.g., Doe v. Moore, 410 F.3d 1337, 1347 (11th Cir. 2005) (upholding Florida's decision to require sex offenders, but not other criminal offenders, to register).

${ }^{290}$ See, e.g., Jones v. Solis, 121 F. App'x 228, 229-30 (9th Cir. 2005) (upholding California's decision to require registration of those convicted of oral copulation with a minor but not those convicted of sexual intercourse with a minor).

${ }^{291} 381$ F. Supp. 2d 443, 451 (E.D. Pa. 2005).

292271 F. Supp. 2d 649, 664 (W.D. Pa. 2003). In an earlier decision, Doe v. Ward, 124 F. Supp. 2d 900, 916 (W.D. Pa. 2000), the Western District held that Pennsylvania's Interstate Compact Concerning Parole precluded the Commonwealth from placing "extraneous conditions" on out-of-state but not in-state registrants before subjecting them to community notification.

${ }^{293}$ Under Pennsylvania law at the time, only registrants deemed "sexually violent predators" were subject to community notification. Under current law, effective January 2005, all registrants are subject to community notification via the Internet. See McVey, 381 F. Supp. 2d at 446 n.4 (discussing 42 PA. Cons. StAT. AnN. § 9798.1 (2005)). 
In McVey, the most recent decision, Judge Pollak rejected each of the Commonwealth's proffered justifications for distinguishing residents on the basis of where a predicate offense occurred, concluding that the classification failed to satisfy rational basis review. ${ }^{294}$ First, Judge Pollak dismissed the asserted cost-savings involved, concluding that " $[w]$ hile Pennsylvania might have a legitimate interest in saving money, it may not achieve this end by discriminating among similarly situated citizens." ${ }^{295}$ Second, Judge Pollak rejected the Commonwealth's asserted goal of not "becom[ing] a haven for sex offenders, even though they are not sexually violent predators, by encouraging them to seek the anonymity that they lost in the state where they were convicted." ${ }^{296}$ To Pollak, the desire to not become a "haven" was "unlikely" to be a constitutionally permissible goal, ${ }^{297}$ and at any rate did not justify withholding due process rights from similarly situated out-of-state registrants. ${ }^{298}$

Finally, Judge Pollak gave short shrift to the Commonwealth's argument that the classification was justified because Pennsylvania's residents are less likely to be aware of the offense/offender "in the daily public discourse or through the media than would be the case for an in-state offender." "'99 Invoking the Western District's analysis in Lines, Judge Pollak reasoned that this same knowledge deficit was at play with respect to in-state registrants, and indeed motivated and justified registration and notification laws more generally. ${ }^{300}$ As a result, to Pollak "any concern over the public's lack of knowledge about outof-state offenders applies with equal force to in-state offenders and, therefore, cannot justify Pennsylvania's disparate treatment of the two groups." 301

The outcomes in McVey and Lines, while surely cause for optimism among the defense bar, should be greeted with some reserve, however, insofar as the constitutionality of external variety laws in general is concerned. This is so for several reasons. First, the claims in each case concerned community notification which, unlike registration alone, has traditionally inspired greater judicial concern due to its

294 Id. at 451.

295 Id. at 450.

296 Id. (quoting Brief for Defendant at 24)

297 Id. at 450 n. 8.

298 Id. at 450.

299 Id. (quoting Brief for Defendant at 24).

300 Id.

301 Id. at 451. 
more burdensome effects. ${ }^{302}$ Second, Pennsylvania law, as of January 2005, did away with the two-track notification scheme for in- and outof-state offenders (the only such regime in the nation), mooting the analytic rubric. ${ }^{303}$ In sum, courts, as they have been inclined to do with registration-related claims more generally, will very likely be inclined to find, as they have with recidivists, that any in- versus out-ofstate classification itself is not cause for equal protection concern. ${ }^{304}$

Assuming that classification itself fails to pose a problem, an equal protection concern might arise because a fundamental right is differentially infringed by registration. Conceivably, the privacy intrusions attending registration (and especially notification) might be thought to jeopardize the right to privacy. Courts, however, have rejected such challenges. ${ }^{305}$ The differential impact on the right to travel also might serve as a basis for challenge. However, again, courts have not been amenable to such claims. ${ }^{306}$

A claim sounding in privileges and immunities, based on the argument that the forum treats incoming ex-offenders differently than it treats its indigenous population, might hold greater promise. In Saenz

302 See, e.g., In re Risk Level Determination of C.M., 578 N.W.2d 391, 399 (Minn. Ct. App. 1998) (precluding notification, but not registration, when an individual is charged with, but not convicted of, a statutorily enumerated offense requiring registration).

303 Act of Nov. 24, 2004, 2005 Pa. Laws 152, secs. 7-8 (amending 42 PA. Cons. STAT. $\$$ 9792, 9795.1-.2 (2002)).

${ }^{304}$ Despite the pessimistic view expressed in the text, a recent decision from the Ninth Circuit suggests that California law might present an equal protection difficulty. In Beene $v$. Terhune, the court noted that California requires out-of-state juvenile offenders to register regardless of when they committed their offense, but requires instate juvenile offenders to register only if they committed their offense after 1986. 380 F.3d 1149, 1152 (9th Cir. 2004). The State conceded that if the provision applied, the case "might present an 'equal protection problem.'" Id. Because the Arkansas records were unclear on whether Beene was adjudicated as a juvenile, however, the issue was not squarely addressed by the panel. Id. at 1153 .

305 See, e.g., Hendrix v. Taylor, 579 S.E.2d 320, 324 (S.C. 2003) ("[P] rivacy protections do not extend to information about a sexual offense Appellant committed in another state, which became a matter of public record when Appellant registered as a sex offender in [the foreign state]."). South Carolina's external approach registration law satisfied rational basis review in Hendrix because "the purpose of the law is to protect the public welfare and to assist law enforcement in accomplishing that goal." Id. Deferring to a foreign state's registration decision was a "reasonable method" of achieving public protection. Id.

306 See, e.g., State v. Wigglesworth, 63 P.3d 1185, 1190 (Or. Ct. App. 2003) (concluding that registration does not impinge the constitutional right to free travel); $E x$ Parte Robinson, 80 S.W.3d 709, 716 (Tex. App. 2002) (holding that registration, rather than denying appellant his fundamental right to travel, at most "demonstrated an indirect burden on his right to travel”), aff'd, 116 S.W.3d 794 (Tex. Crim. App. 2003). 
v. Roe, the Court invoked the Fourteenth Amendment's Privileges and Immunities Clause to invalidate a law that, akin to the external variety of laws examined here, permitted newcomers to receive welfare benefits only to the extent permissible under the law of their former state of residence. ${ }^{307}$ Observing that the Clause removes "the disabilities of alienage" from state citizens entering other states in the Union and affords them "equality of privilege with citizens of [the host] States," 308 the majority concluded:

The "right to travel" discussed in our cases embraces at least three different components. It protects the right of a citizen of one State to enter and to leave another State, the right to be treated as a welcome visitor rather than an unfriendly alien when temporarily present in the second State, and, for those travelers who elect to become permanent residents, the right to be treated like other citizens of that State.

By extension, the differential treatment of offenders might raise constitutional concern. Unlike Saenz, however, which involved the disparate distribution of subsistence benefits, subjecting individuals to unequal registration and recidivist sentence enhancements would not likely implicate a constitutionally protected interest. ${ }^{310}$ Moreover, while in effect external laws might discourage interstate migration, the laws, unlike the two-track welfare benefits invalidated in Saenz, are not expressly enacted with this intent, which was of particular concern to the Court. ${ }^{311}$ And even if the courts were to be persuaded otherwise, a forum state could still likely defend its action by showing that valid "reasons do exist and [that] the degree of discrimination bears a close relation to them." ${ }^{312}$ This is especially so given the significant judicial deference afforded state criminal justice policies, even those harshly out of kilter compared to the nation as a whole. ${ }^{313}$

${ }^{307} 526$ U.S. 489, 504-07 (1999).

308 Id. at 502.

${ }^{309} I d$. at 500.

310 See JOHN E. NOWAK \& RONALD D. ROTUNDA, CONSTITUTIONAL LAW § 14.38, at 1066-67 (7th ed. 2004) (noting that to be actionable, a law must "constitute[] a substantial impairment" of a fundamental right and serve as "a significant deterren[t] to persons migrating into a state"); see also id. at 1065 (noting that the Privileges and Immunities Clause of Article IV prohibits "restricting certain basic rights, such as the ability to engage in private sector commercial activity or the ability to exercise a constitutionally protected liberty").

${ }^{311}$ See Saenz, 526 U.S. at 506 (acknowledging that "such a purpose would be unequivocally impermissible").

312 Toomer v. Witsell, 334 U.S. 385, 396 (1948).

313 The Court's decision in Ewing v. California, 538 U.S. 11 (2003), is a case in point. In Ewing, a 5-4 majority upheld against an Eighth Amendment attack Califor- 
Finally, any procedure-based challenge would also likely fail. Recidivist enhancements have long been impregnable to due process challenges, on the reasoning that prior convictions (wherever they occur) are "circumstances" individuals have already had a procedurally safeguarded chance to contest. ${ }^{314}$ Likewise, while room now exists to challenge consideration of the extra-judicial record in enhancement eligibility decisions, and perhaps even to challenge the "prior conviction exception" as a whole, pursuant to the Court's recent decision in Shepard, thereby requiring that juries play a greater role in eligibility determinations, $\mathrm{T}^{315}$ the constitutional integrity of interconnection itself would remain intact.

The prospects for mounting a procedure-based challenge to registration are only somewhat less bleak. In Connecticut Department of Public Safety v. Doe, the Supreme Court concluded that states need not afford individuals any procedural rights and protections before mandating registration and community notification. ${ }^{316}$ In so doing, the Court attached particular importance to the fact that the challenged Connecticut law was triggered solely on the basis of a conviction for a statutorily enumerated offense, not any finding or inference that an individual was "currently dangerous." 317 Because the law was applied automatically, and did not hinge on proof of a particular fact (i.e., "dangerousness"), the Court did not address whether a protectible liberty interest was implicated, warranting due process. ${ }^{318}$ However, the vast majority of federal courts addressing the question have concluded that registration and community notification do not

nia's three strikes law, the harshest in the nation, noting the Court's "tradition of deferring to state legislatures in making and implementing such important policy decisions." Id. at 24. While agreeing that the law had "sparked controversy," the majority also observed with seeming approval its "unintended but positive consequence" of encouraging parolees to leave the state. Id. at 27 (citation omitted); see also Spencer v. Texas, 385 U.S. 554, 566 (1967) ("Tolerance for a spectrum of state procedures . . is especially appropriate here. The rate of recidivism is acknowledged to be high, a wide variety of methods dealing with the problem exists, and experimentation is in progress.").

${ }^{314}$ See, e.g., Goodman v. Kunkle, 72 F.2d 334, 336 (7th Cir. 1934) (noting that recidivist statutes "do not create or define a new or independent crime, but they prescribe circumstances wherein one found guilty of a specific crime may be more severely penalized because of his previous criminalities as they are alleged and found").

315 See supra notes 194-99 and accompanying text.

316 538 U.S. 1, 7-8 (2003).

${ }^{317} I d$. at 7 .

${ }^{318} I d$. 
threaten a liberty interest. ${ }^{319}$ As a result, any procedural claim would likely be doomed as a threshold matter for want of a protectible liberty interest, ${ }^{320}$ mooting any argument that internal approach laws (unlike the Connecticut statute in Doe) condition registration eligibility on something more than merely whether a prior conviction for an enumerated offense exists. ${ }^{321}$

\section{THE FEDERALISM IMPLICATIONS OF INTERCONNECTION}

As the preceding discussion makes clear, interconnection has major implications for states and individuals alike. By its very nature, however, interconnection also unavoidably implicates federalism, its

319 See, e.g., Cutshall v. Sundquist, 193 F.3d 466, 478 (6th Cir. 1999) (holding that registration and community notification do not threaten a constitutionally protected liberty interest); Russell v. Gregoire, 124 F.3d 1079, 1094 (9th Cir. 1997) ("Since we have already rejected their privacy claims, we conclude that [the defendants] have no liberty interest at stake, and hence we reject their due process claims.").

${ }^{320}$ Conceivably, reviewing courts might attach significance to the fact that foreign convictions, unlike indigenous ones on record in the forum, are less likely to be within the ken of forum residents, thus lessening the likelihood of stigma. See, e.g., Russell, 124 F.3d at 1094 (deeming it important that conviction and offender residence information are otherwise publicly available in the jurisdiction); Femedeer v. Haun, $35 \mathrm{~F}$. Supp. 2d 852, 861 (D. Utah 1999) (concluding that conviction and address information are not protected because of their public availability); Doe v. Kelly, 961 F. Supp. 1105, 1112 (W.D. Mich. 1997) (explaining that the Michigan statute "does nothing more than compile truthful, public information and make it available"). However, such an outcome seems unlikely given the judicial predisposition to indulge the fantasy that forum residents would take it upon themselves to assemble the otherwise diffused information collectively purveyed by notification. Furthermore, with the increasing availability of state conviction records on the Internet, any such argument is additionally weakened. See Doron Teichman, Sex, Shame, and the Law: An Economic Perspective on Megan's Laws, 42 HARV. J. ON LEGIS. 355, 380-81 (2005) (noting that approximately forty states and the District of Columbia currently operate sex offender registry websites); see also supra note 23 (noting National Sex Offender Public Registry, which promises to "provide one-step access to registries" nationwide).

${ }^{321}$ In Creekmore v. Attorney General, 341 F. Supp. 2d 648, 665 (E.D. Tex. 2004), the court adopted the highly unusual position that the burdens associated with registration, alone, implicated a liberty interest and distinguished the Supreme Court's holding in Doe. According to the court, unlike the Connecticut law at issue in Doe, Texas law required that an out-of-state prior offense resulting in conviction be "substantially similar" to a statutorily prescribed offense warranting registration in Texas. Id. While prior Texas convictions for any such prescribed offenses might properly trigger automatic registration, the comparative law analysis required for out-of-state registrants involved a "contested fact" that was legally material to the Texas registration requirement, compelling that due process be afforded. Id. at 665-66. Ultimately, however, the court rebuffed Creekmore's facial challenge to the law, concluding that the Texas regime, see supra notes 151-52 and accompanying text, contained sufficient due process protections, but that they were not extended in Creekmore's case. Creekmore, $341 \mathrm{~F}$. Supp. $2 \mathrm{~d}$ at 667. 
horizontal genus in particular. The decisions by states to use the criminal justice outcomes of their fellow states, and their decisions on which evaluative approach to adopt (external or internal), shed important light on the functional and theoretical effects of horizontal federalism.

\section{A. The Internal Approach}

In a fundamental sense, internal approach states can be considered stalwarts of "fifty-labs" federalism. By insisting that foreign convictions warrant recidivist or registration treatment under their own laws, and not deferring to the judgments of the states where the convictions occurred, the states reify federalist values of self-governance and autonomy. While perhaps representing a slap in the face in terms of comity, the absence of deference underscores such states' resolve to honor their own criminal law standards and the normative positions they represent. As recently noted by the Georgia Supreme Court:

A state cannot express its public policy more strongly than through its penal code. When a state defines conduct as criminal and sets the punishment for the offender, it is conveying in the clearest possible terms its view of public policy. Full faith and credit ordinarily should not require a state to abandon such fundamental policy in favor of the public policy of another jurisdiction. ${ }^{322}$

By sticking to their sovereign guns, and adhering to recidivist and registrant eligibility criteria prescribed by their own legislatures, internal jurisdictions also serve the experimentalist values of federalism in a more indirect way. To the extent that interconnection functions to promote inter-governmental dialogue, ${ }^{323}$ if policy makers in the foreign state are listening, ${ }^{324}$ and they desire continued accountability of

${ }^{322}$ State v. Langlands, 583 S.E.2d 18, 20 n.4 (Ga. 2003); see also State v. Clough, 829 P.2d 1263, 1265 (Ariz. Ct. App. 1992) ("The obvious purpose of [the state's internal approach recidivist law] is to preclude the enhancement of a sentence if the conduct which led to a conviction in another state has not been judged by our legislature to be so egregious ... as to justify treating it as a felony.").

${ }^{323}$ The prospect was advanced most visibly by Justice Brennan with regard to vertical federalism. See William J. Brennan, Jr., The Bill of Rights and the States: The Revival of State Constitutions as Guardians of Individual Rights, 61 N.Y.U. L. REV. 535, 548 (1986) ("[T] he Court's contraction of federal rights and remedies on grounds of federalism should be interpreted as a plain invitation to state courts to step into the breach.").

${ }^{324}$ The experimentalist tradition in criminal justice is an ongoing, vibrant one, with countless innovative methods having originated in individual states only to be copied by fellow states (and even the federal government). See Susan R. Klein, Independent-Norm Federalism in Criminal Law, 90 CAL. L. REV. 1541, 1557 (2002) (noting state 
and social control over their migrating offenders, ${ }^{325}$ rejection by the internal state of the prior conviction might serve to hasten legal evolution there. This can entail changes to substantive law, such as clarifying aspects of statutory language, ${ }^{326}$ or procedures, such as when the foreign state provides less in the way of access to counsel or jury trial rights than the forum. ${ }^{327}$

Whether such change itself is salutary, of course, is in the eye of the beholder. For instance, offenders convicted of carrying a concealed weapon in the North, where such an offense commonly is punished harshly, can often travel south (where firearms are more loosely regulated) free of worry that their felony record will pose a risk of recidivist enhancement. ${ }^{328}$ Similarly, a conviction for possessing illegal drugs might warrant felony status in one state that takes an especially negative view of drug use, yet might be sanctioned mildly in another with a more lenient view. ${ }^{329}$ Under both circumstances, the forum's critical approach might encourage the foreign states to reconsider their harsh stance. On the other hand, the forum state's refusal to consider a foreign conviction because the offense did not warrant felony status there might prompt the foreign state to punish the offense more harshly. ${ }^{330}$

\footnotetext{
innovations including "boot camps, drug courts, and shaming devices"); Reitz, supra note 15, at 128 (noting that major penological movements have emanated from the state and local level, including modern sentencing guidelines and sentencing commission initiatives).

${ }^{325}$ As discussed later, there is some reason to doubt, however, that foreign jurisdictions have much incentive to care how another jurisdiction later handles an erstwhile resident ex-offender. See infra note 386 and accompanying text.

${ }^{326}$ See, e.g., Timothy v. State, 90 P.3d 177, 180 (Alaska Ct. App. 2004) (rejecting a prior foreign burglary conviction due to statutory ambiguity).

${ }^{327}$ See, e.g., State v. Sinagoga, 918 P.2d 228, 238 (Haw. Ct. App. 1996) (refusing to consider a prior foreign uncounseled conviction).

${ }^{328}$ See, e.g., Poole v. State, 445 So. 2d 967, 973 (Ala. Crim. App. 1983) (rejecting a Michigan felony conviction for carrying concealed weapon because the offense was not deemed a felony in Alabama).

329 See supra note 13 (noting the varied positions of North Dakota and Minnesota on marijuana possession); cf. Commonwealth v. Shaw, 744 A.2d 739, 744 (Pa. 2000) (rejecting a New York DUI conviction because the offense was triggered by "an appreciably lesser degree of impairment").

330 See, e.g., State v. Decker, 833 P.2d 704, 706 (Ariz. 1992) (rejecting a prior Iowa conviction because it was classified as an aggravated misdemeanor there, despite being classified as a felony in Arizona).
} 


\section{B. The External Approach}

The federalism implications of the external approach are at once more ambiguous and potentially more profound. In one sense, by deferring to outcomes in other states, the external approach honors state diversity and gives it effect. The approach embodies the notion that " $[\mathrm{g}]$ ood citizenship requires obedience and observance to the laws of sister states as much as those of this state." ${ }^{331}$ Much as the U.S. Constitution's Extradition Clause requires a state to surrender to another state an individual who has violated that state's criminal law, regardless of whether the behavior violates the law of the surrendering state, ${ }^{332}$ the external approach places premium importance on comity. ${ }^{333}$ Compared to the internal approach, which permits itinerant exoffenders to slip through the cracks as a result of its interpretive process, ${ }^{334}$ the external approach also better ensures continued accountability of offenders and hence serves more aggressive social control interests. It does so by tying registration and recidivist enhancement decisions to not just its own criteria, but those of other states as well.

Yet by the same token, there is no mistaking that the external approach, in achieving these goals, entails a disavowal of state autonomy. The ramifications of this for horizontal federalism are several-fold.

\section{Democratic Representativeness}

First and perhaps foremost, the external approach undercuts the democratic representativeness of the criminal law. By bootstrapping

331 State v. Prince, 132 P.2d 146, 149 (Idaho 1942).

${ }^{332}$ U.S. Const. art. IV, § 2; see also Puerto Rico v. Branstad, 483 U.S. 219, 226 (1987) ("[T] $[$ he Extradition Clause creates a mandatory duty to deliver up fugitives upon proper demand ....”).

${ }^{333}$ See Franchise Tax Bd. v. Hyatt, 538 U.S. 488, 493 (2003) (stating that comity is "an accommodation policy, under which the courts of one state voluntarily give effect to the laws and judicial decisions of another state out of deference and respect, to promote harmonious interstate relations").

${ }^{334}$ For criticism to this effect, see Galt, supra note 24, at 1135-39 (discussing the capacity of New York law to permit migrating offenders to escape recidivist accountability). Alaska law, however, provides an interesting example of governmental responsiveness in this regard. In Scroggins v. State, 951 P.2d 442, 444 (Alaska Ct. App. 1998), the court refused to find that the defendant's prior California conviction for lewd and lascivious acts upon a child was "similar" to any Alaska felony, and therefore refused to enhance his sentence. The legislature thereafter amended its recidivist law to specifically allow for this precise crime to be deemed a prior felony. See ALASKA STAT. § 12.55.145(a)(4)(B) (2004) ("[A] felony conviction in another jurisdiction making it a crime to commit any lewd and lascivious act upon a child under the age of sixteen years ... is a prior conviction for a sexual felony ...."). 
value judgments of their fellow sovereigns, external approach states flout the premise that state criminal laws reciprocally reflect ${ }^{335}$ and shape $^{336}$ the normative views of the jurisdiction that enacts them. As Dan Kahan has observed, the criminal law is "suffused with meaning. What it punishes (drug possession, sodomy) can tell us what kind of life the community views as virtuous; how it punishes (imprisonment, corporal punishment, fines) can tell us what forms of affliction it views as appropriate to mark wrongdoers' disgrace...." ${ }^{337}$ While some have argued that the decentralizing effect of federalism in itself fails to ensure politically representative, localized governance, ${ }^{338}$ the external approach renounces outright any such prospect, and with it what the Anti-Federalists lauded as state "individuality." 339 Much as a ventriloquist uses a dummy, states employing the external approach mimic the value judgments of other states ${ }^{340}$ with the revered "fifty

335 See Atkins v. Virginia, 536 U.S. 304, 312 (2002) (observing that the "clearest and most reliable objective evidence of contemporary values is the legislation enacted by the country's legislatures" (quoting Penry v. Lynaugh, 492 U.S. 302, 331 (1989))); Morris R. Cohen, Moral Aspects of the Criminal Law, 49 YALE L.J. 987, 1017 (1940) ("It is one of the functions of the criminal law to give expression to the collective feeling of revulsion toward certain acts, even when they are not very dangerous ....").

${ }^{336}$ See Stuart P. Green, Why It's a Crime to Tear the Tag Off a Mattress: Overcriminalization and the Moral Content of Regulatory Offenses, 46 EMORY L.J. 1533, 1555-56 (1997) (" $[\mathrm{J}]$ ust as the decision to make certain conduct criminal reflects publicly-held moral norms, so too are public perceptions of morality affected by what has been made criminal. The relationship that public morality and the criminal law bear to each other is thus a reciprocal one."); see also Paul H. Robinson \& John M. Darley, The Utility of Desert, 91 Nw. U. L. REv. 453, $471-77$ (1997) (providing an overview of the law's influence on the creation of social norms).

${ }^{337}$ Dan M. Kahan, Social Influence, Social Meaning, and Deterrence, 83 VA. L. REV. 349, 362 (1997); see also id. at 365 (referring to the "criminal law as a political institution"); Dorothea Kübler, On the Regulation of Social Norms, 17 J.L. ECON. \& ORG. 449, 451 (2001) (defining a norm as "a moral expectation shared by a group of people, entailing social stigmatization or at least moral indignation aimed at those who deviate").

338 See, e.g., DAVID L. Shapiro, Federalism: A Dialogue 93 (1995) (contending that some states are too large and diverse to reflect local concerns); $c f$. KENNETH J. ARROW, SOCIAL CHOICE AND INDIVIDUAL VALUES 46-60 (2d ed. 1963) (discussing theoretical barriers to incorporating individual concerns into collective preferences).

339 See SAMUel H. BeER, TO MAKe a NATION: THE Rediscovery OF AMERICAN FEDERALISM 239 (1993) (quoting Dr. Johnson of Connecticut who observed that the Anti-Federalists saw "the states as 'so many political societies,' each with its 'individuality,' while the [Federalists] considered the states as merely 'districts of people composing one political Society'”). On this point more generally, see Timothy Zick, Statehood as the New Personhood: The Discovery of Fundamental "States' Rights," 46 WM. \& MARY L. REV. 213, 226-43 (2004).

${ }^{340}$ The concept is borrowed from Justice Scalia who, in an anti-commandeering case invalidating congressional efforts to require states to implement the federal handgun control legislation, condemned Congress's having "dragooned" state officials and 
labs" model of horizontal federalism, and the dynamism and diversity it hopefully entails, consequently diminished. ${ }^{341}$

In turn, by creating a legal landscape in which it becomes difficult to ascribe value judgments with geo-political accuracy, the external approach also functions to undermine governmental transparency and political accountability. ${ }^{342}$ By deferring to the laws of other sovereigns, forum state officials become free riders: they avoid any possible negative political consequences that might attend enforcement of such laws in the first instance in the forum. ${ }^{343}$ For instance, a state with an external approach registration law can effectively codify "peeping" (South Carolina) or adultery (Kansas) as convictions requiring registration, if it is otherwise politically wary of adopting the requirements via the formal legislative process. ${ }^{344}$ The external ap-

reduced states to "puppets of a ventriloquist Congress." Printz v. United States, 521 U.S. 898, 928 (1997) (citations omitted).

${ }^{341}$ The internal approach raises political representativeness concerns as well, although not nearly so distinct. State legislatures adopting internal laws (especially with broad language) in effect cede their lawmaking authority to executive branch actors (prosecutors), who have discretion whether to invoke such laws and tender legal arguments in support. See William J. Stuntz, The Pathological Politics of Criminal Law, 100 MiCH. L. REV. 505, 509 (2001) ("As criminal law expands, both lawmaking and adjudication pass into the hands of police and prosecutors; law enforcers, not the law, determine who goes to prison and for how long."). Another measure is ceded to the judiciary, which must interpret state laws and ascribe meaning to their broad terms. Cf. Dan M. Kahan, Three Conceptions of Federal Criminal-Lawmaking, 1 BUFF. CRIM. L. REV. 5, 6-11 (1997) (asserting that by enacting broad statutes, Congress effectively cedes power to define the scope of criminal laws to the judiciary).

${ }^{342}$ Just such a concern inspired the Supreme Court, in New York v. United States, 505 U.S. 144, 168-69 (1992), to invalidate Congress's attempt to commandeer New York to dispose of low-level radioactive waste within its borders. Writing for the Court, Justice O'Connor noted:

Where the Federal Government directs the States to regulate, it may be state officials who will bear the brunt of public disapproval, while the federal officials who devised the regulatory program may remain insulated from the electoral ramifications of their decision. Accountability is thus diminished when ... elected state officials cannot regulate in accordance with the views of the local electorate in matters not pre-empted by federal regulation.

$I d$. at 169; see also id. at 183 (noting that when governments combine their efforts to disguise responsibility, "federalism is hardly being advanced").

${ }^{343}$ However, the legerdemain ultimately carries undisputed (non-political) costs: the financial expenditures associated with imposing registration requirements (possibly along with community notification) and enhancing prison terms, borne by the forum state alone. Moreover, defendants faced with enhancement might be less likely to plead guilty and decide to pursue trials in the forum instead, which would entail additional associated costs.

${ }^{344}$ This also serves to provide political cover for judges and prosecutors, especially when they must stand for popular election. 
proach thus permits jurisdictions to indulge in a kind of stealth legislation: laws are applied by the forum without having been subject to the debate and compromise common to the legislative process, ${ }^{345}$ depriving the public of an important occasion for norm identification and support. ${ }^{346}$ While it might be the case that the imported value judgment parallels that of the forum, this is not necessarily so, and the stealth quality of the approach undercuts the consensus-based (or at least majority-approved) value choices a formal law embodies. ${ }^{347}$

Importantly, this outcome does not derive from any strong-arm political measure by another sovereign, such as occurs in instances of federal commandeering. ${ }^{348}$ Nor does it stem from a "[d]enial of [states'] right to experiment," the concern animating Justice Brandeis in New State Ice, ${ }^{349}$ as occurs with federal usurpation of state criminal law prerogatives under vertical federalism; ${ }^{350}$ nor from any constitutional compulsion, such as the Full Faith and Credit Clause, requiring

${ }^{345}$ The situation presents an interesting contrast with the phenomenon of codified criminal laws that go unenforced. See Christopher R. Leslie, Creating Criminals: The Injuries Inflicted by "Unenforced" Sodomy Laws, 35 HARV. C.R.-C.L. L. REV. 103 (2000) (discussing the social harms caused by unenforced sodomy laws and the legitimacy they lend to prejudice). Here, rather than being formally enacted yet not enforced, the laws are enforced yet not formally enacted.

${ }^{346}$ As Paul Robinson has noted, the legislative process provides "an occasion for public debate that can help build norms, with the conclusion of the debate announced by legislative action, or inaction." Paul H. Robinson, Why Does the Criminal Law Care What the Layperson Thinks Is Just? Coercive Versus Normative Crime Control, 86 VA. L. REV. 1839, 1867 (2000); see also id. at 1868-69 ("The criminal law is ... a contributing mechanism by which the norm-nurturing process moves forward .... Our criminal law is, for us, the place we express our shared beliefs of what is truly condemnable.").

347 See Henry M. Hart, Jr., The Aims of the Criminal Law, 23 LAW \& CONTEMP. Probs. 401, 405 (1958) (describing criminal laws as embodying the "formal and solemn pronouncement of the moral condemnation of the community"). Use of the term "formal" here is in no way intended to mean legal formalism. As Elizabeth Anderson and Richard Pildes have pointed out:

Appropriate concern with form in law should not be equated with legal formalism. Legal formalism entails applying legal rules, categories, concepts, and forms without regard to the underlying purposes or values those rules ought to serve. Expressive constraints, by contrast, pay attention to these underlying purposes and values. Nothing in expressivist concern for form requires that such a concern be applied in a wooden, mechanical way.

Elizabeth S. Anderson \& Richard H. Pildes, Expressive Theories of Law: A General Restatement, 148 U. PA. L. REV. 1503, 1564 n.184 (2000).

348 See supra note 342.

${ }^{349}$ New State Ice Co. v. Liebmann, 285 U.S. 262, 311 (1932) (Brandeis, J., dissenting).

${ }^{350}$ See supra note 27. 
one state to recognize another's penal judgment, as none exists. ${ }^{351}$ Rather, the disempowerment is self-willed and self-imposed. ${ }^{352}$ Despite states' unquestioned sovereignty in the criminal law realm, which is so powerful that it permits multiple states to successively prosecute and convict the same individual for identical criminal misbehavior, ${ }^{353}$ the states self-consciously defer to the laws and judgments of their fellow governments.

In so doing, external approach states forsake what Professors Baker and Young have called the "negative freedom" of federalismthe right to act autonomously and independently, free of the constraining authority of other governmental units. ${ }^{354}$ Over eighty years ago, some ten years before Justice Brandeis' language in New State Ice, Justice Holmes extolled the capacity of federalism to foster "social experiments... in the insulated chambers afforded by the several states." 355 The external approach ignores this invitation and thus gainsays a central animating value of horizontal federalism. ${ }^{356}$

${ }^{351}$ See Nelson v. George, 399 U.S. 224, 229 (1970) (“[T]he Full Faith and Credit Clause does not require that sister States enforce a foreign penal judgment . ..." (citations omitted)); Williams v. North Carolina, 317 U.S. 287, 294 n.6 (1942) ("It has been repeatedly stated that the full faith and credit clause does not require one state to enforce the penal laws of another.").

${ }^{352}$ See Huntington v. Attrill, 146 U.S. 657, 669 (1892) (noting that state criminal laws "can have extraterritorial effect only by the comity of other States"); Clark v. Gladden, 432 P.2d 182, 185 (Or. 1967) ("No state is required to take notice of foreign convictions in sentencing those who violate its own criminal laws. Each state is free to give foreign convictions such force as it deems proper in the administration of local sentencing policy.").

${ }^{353}$ See Heath v. Alabama, 474 U.S. 82, 88 (1985) (upholding the right of Alabama to prosecute a defendant and seek the death penalty when Georgia had already imposed a life term on the defendant for the same killing on the basis of the "dual sovereignty doctrine"); see also id. at 93 ("A State's interest in vindicating its sovereign authority through enforcement of its laws by definition can never be satisfied by another State's enforcement of its own laws.").

${ }^{354}$ Lynn A. Baker \& Ernest A. Young, Federalism and the Double Standard of Judicial Review, 51 DUKE L.J. 75, 134 (2001). As Professor Young alone recently observed, "state governments cannot provide fora for political participation and competition unless meaningful decisions are being made in those fora." Ernest A. Young, The Rehnquist Court's Two Federalisms, 83 TEX. L. REV. 1, 52 (2004).

${ }^{355}$ Truax v. Corrigan, 257 U.S. 312, 344 (1921) (Holmes, J., dissenting); see also Deborah J. Merritt, Federalism as Empowerment, 47 FLA. L. REV. 541, 541-42 (1995) (surveying the various ways in which federalism empowers states to experiment with solutions to social problems).

${ }^{356}$ Sara Sun Beale, Too Many and Yet Too Few: New Principles to Define the Proper Limits for Federal Criminal Jurisdiction, 46 HASTINGS L.J. 979, 993-94 (1995) ("A decentralized federal system ... permits criminal justice policy to be tailored to local conditions and policy preferences; and it furthers political accountability."); $c f$. Kevin N. Wright, The Desirability of Goal Conflict Within the Criminal Justice System, 9 J. CRIM. JUST. 209, 214- 


\section{Pluralism and Competition}

In a related sense, the external approach impairs the pluralism and competition ideally fostered by autonomous state rule. With its predominant emphasis on comity, the approach ultimately constricts the range of normative choices available to individuals, diminishing what Alexander Hamilton called the competition "for the people's 'affection." "'557 This competition, Hamilton reasoned, has particular resonance with respect to the administration of justice, "the most powerful, most universal, and most attractive source of popular ... attachment" because it is "the immediate and visible guardian of life and property." ${ }^{358}$

If prior convictions constitute indelible matters of record, transgeographically affecting recidivism and registration decisions, as is the case with the external approach, geography is permitted to determine destiny ${ }^{359}$ - and individuals with such records will naturally be less inclined to move. ${ }^{360}$ This, one might infer, is the precise objective of legislators in such states-to discourage ex-offenders from moving into their states. Nonetheless, by in effect making laws more uniform, the

15 (1981) (endorsing diversity because it permits inevitable conflicts in community values to be fleshed out and resolved).

${ }^{357}$ Todd E. Pettys, Competing for the People's Affection: Federalism's Forgotten Marketplace, 56 VAND. L. REV. 329, 332 (2003) (quoting THE FEDERALIST No. 17, at 120 (Alexander Hamilton) (Clinton Rossiter ed., 1961)).

${ }^{358}$ THE FEDERALIST NO. 17, supra note 357, at 120.

359 See Bernhard Grossfeld, Geography and Law, 82 MICH. L. REV. 1510, 1512-13 (1984) (observing generally that "geography is fate . . not only for a country, but also for its culture and its law").

${ }^{360}$ This presumes, of course, that ex-offenders are aware of the registration and/or recidivist provisions of the state to which they might move. Charles Tiebout advanced the tenet that decentralized governance enables citizens to "vote with their feet" by moving to jurisdictions with laws that most benefit them. See Tiebout, supra note 3, at 418 ("The consumer-voter may be viewed as picking that community which best satisfies his preference pattern for public goods.”). Tiebout himself acknowledged that his analytic model presumed adequate legal knowledge of such comparative differences, which of course does not always reflect reality. See id. at 419 ("Consumer-voters are assumed to have full knowledge of differences among revenue and expenditure patterns and to react to those differences."). While ex-offenders arguably have greater incentives to conduct comparative legal analysis, given that their liberty is at stake, there is little reason to think that they would be any better informed, and thus equipped to choose, in this regard. Indeed, such competence is even less likely given the lower social and educational status of many ex-offenders. Cf. Richard Briffault, Our Localism: Part II-Localism and Legal Theory, 90 CoLum. L. REV. 346, 420-21 (1990) (suggesting that interjurisdictional mobility is constrained by "economic and social factors that tend to affect poorer people more than affluent ones" and that "investors of capital and owners of businesses, rather than residents, are the prime beneficiaries of" relocation options). 
external approach discourages exit rights, ${ }^{361}$ and limits freedom of movement, an accepted constitutional good. ${ }^{362}$ In a more instrumental sense, the approach can hinder the free transfer of human and social capital by, for instance, discouraging persons convicted of sodomy or peeping from migrating. Consequently, the prospective state residence may be deprived of such persons' talents and resources. As a result, overdeterrence can occur with consequent social inefficiencies being created. ${ }^{363}$

In short, ex-offenders atavistically become tribe-like members of the state in which their conviction occurred, ${ }^{364}$ ineradicably marked by the values and criminal law norms of their erstwhile residences, contrary to the free movement ideals of the nation's federal republic. ${ }^{365}$

\section{Race-to-the-Bottom Consequences}

Finally, the external approach can ultimately have race-to-thebottom consequences. While the concept is most familiar to economic and environmental concerns, ${ }^{366}$ a similar scenario is susceptible

361 See Larry E. Ribstein \& Bruce H. Kobayashi, An Economic Analysis of Uniform State Laws, 25 J. LEGAL STUD. 131, 140 (1996) ("[U]niform state laws tend to decrease exit opportunities.").

${ }^{362}$ See supra note 177 and accompanying text; see also JOHN HART ELY, DEMOCRACY AND DISTRUST: A THEORY OF JUDICIAL REVIEW 178-79 (1980) (asserting that the right to travel is important because it protects an individual's capacity to leave an "oppressive" community "and relocat[e] in a community whose values he or she finds more compatible").

${ }_{363}$ See generally Gary S. Becker, Crime and Punishment: An Economic Approach, $76 \mathrm{~J}$. POL. ECON. 169 (1968) (discussing the phenomenon of overdeterrence).

${ }^{364}$ As Seth Kreimer has noted, state-based identification is a relic of antebellum thought and behavior:

At the time of the Civil War, Robert E. Lee resigned his federal commission, and renounced his oath of allegiance because as a "Virginian" he could not bear to honor that oath. It is hard today to find a citizen of the United States who conceives of her primary identity as a "Virginian" or a "Pennsylvanian"....

Seth F. Kreimer, Lines in the Sand: The Importance of Borders in American Federalism, 150 U. PA. L. REV. 973, 984 (2003).

${ }^{365}$ As Douglas Laycock has observed, "[t] here are other ways to organize, but we did not choose them. An American state is not like a nomadic tribe, with membership based on kinship .... The state ... is defined by its territory, and 'its people' are defined by the territory in which they live." Douglas Laycock, Equal Citizens of Equal and Territorial States: The Constitutional Foundations of Choice of Law, 92 COLUM. L. REV. 249, 316-17 (1992); see also Lemmon v. People, 20 N.Y. 562, 609 (1860) ("The position that a citizen carries with him, into every state which he may go, the legal institutions of the one in which he was born, cannot be supported.").

366 See, e.g., Paul E. Peterson, The Price OF Federalism 121-24 (1995) (discussing the phenomenon in the context of state welfare laws); Richard L. Revesz, Rehabili- 
of occurring in the criminal justice realm. ${ }^{367}$ This is because criminal justice matters are subject to uniquely potent political pressures. ${ }^{368}$ No politician relishes the prospect of being cast as a coddler of criminals, ${ }^{369}$ especially sex offenders. ${ }^{370}$

In such a climate, the external approach, whereby the harshly idiosyncratic views of a state are exported to other states, can have particular resonance. ${ }^{371}$ For instance, before the Supreme Court invalidated state laws criminalizing consensual homosexual sodomy in Lawrence $v$. Texas, ${ }^{372}$ the external approach would compel recognition of

tating Interstate Competition: Rethinking the "Race-to-the-Bottom" Rationale for Federal Environmental Regulation, 67 N.Y.U. L. REV. 1210, 1213-19 (1992) (discussing the phenomenon in the context of environmental regulations).

${ }^{367}$ The "bottom" relative to criminal justice of course differs from that in the realm of commercial and environmental regulation. With the latter, states wishing to attract business are tempted to adopt laxer laws than they otherwise might. While states might logically be said to be fearful of being perceived as "anti-business," no such apprehension exists over being seen as "anti-criminal." As a result, undue laxness is the risk in the commercial realm, whereas undue harshness is the risk with criminal justice matters as states (and their politicians) endeavor to avoid being perceived as "soft" on crime.

${ }^{368}$ As William Stuntz has observed, "[i]f there is any sphere in which politicians have an incentive simply to please the majority of voters it's criminal law." Stuntz, supra note 341 , at 529-30.

${ }^{369}$ For extended discussions of this effect, see DAVID C. ANDERSON, CRIME AND THE Politics of Hysteria (1995); KATHERINe BecketT, MAKING CRIME PAY: LAW AND ORDER IN CONTEMPORARY AMERICAN POLITICS (1997).

${ }^{370}$ See Janus \& Logan, supra note 284, at 320-21 (noting the wave of harsh laws targeting sex offenders enacted in the 1990s, including registration and community notification provisions, which were rapidly approved in the wake of high-profile sexual victimizations).

${ }^{371}$ Importantly, by definition the external approach operates only in one direction: to systematically import laws of a harsher nature, despite the forum state's more permissive law (i.e., failing to expressly consider the behavior for registration or recidivist purposes). In this vein, Susan Klein has observed a kindred phenomenon in the realm of vertical federalism whereby Congress criminalizes conduct not the subject of state criminalization, or otherwise impedes state laws permitting behavior made criminal by the federal government, for instance with respect to medical marijuana or physician-assisted suicide. Susan R. Klein, Independent-Norm Federalism in Criminal Law, 90 CAL. L. REV. 1541, 1565-79 (2002). In such cases, federal laws intrude upon "statecreated liberty interests." Id. at 1544. Professor Klein reasons that "[w]hen only a few states are outliers, they will probably not succeed, via the national political process, in protecting their citizens from the majority's will." $I d$. "When the state's norm is independent of the federal norm, the outlier state will rarely obtain the allies necessary to win protection from contrary federal legislation in the political process." Id. at 1560 . Here, by analogy, by forsaking its prerogative to not count the foreign conviction, the state is eschewing its own independently created norm.

${ }^{372} 539$ U.S. 558, 578-79 (2003). 
such convictions for purposes of registration. ${ }^{373}$ Despite their laggard status, the states would in effect "rule the nation." ${ }^{374}$ This reflexive recognition, in addition to replicating the initial injustice, could ultimately foster a familiarity and comfort in the forum states with the foreign value judgment, bringing political pressure to formally recognize the laggard position via the legislative process. Similarly, states with laggard procedural rights and those with draconian sentences for drug offenses, for instance, could well catch the notice of more progressive states, fueling a downward spiral of harshness.

Such choices, of course, are part and parcel of the decentralized, autonomous quality of federalism itself. As Lynn Baker has observed, " $\mathrm{t}]$ he freedom of sub-national political communities to choose their own visions of the good society, like any other form of 'diversity,' predictably results in a mixed bag of results." ${ }^{375}$ Yet there is no mistaking that the policy of states adopting the external approach represents a disavowal of this local prerogative, which, as a consequence, permits the "mixed" (typically crime control oriented) decisions of certain states to have effect far beyond their territorial borders. As a result, what Madison called the "republican remedy" to renegade state positions on particular policy matters is undermined: rather than permit-

${ }^{373}$ For examples of pre-Lawrence state laws requiring registration for consensual sodomy convictions, see ALA. CODE $\S 13 A-11-200$ (1994); IDAHO CODE ANN. $§ 18$ 8304(1) (a) (Supp. 2002); KAN. STAT. ANN. § 22-4902(a) (5) (B) (Supp. 2003); LA. ReV. STAT. ANN. $\$ 15: 541(14.1)$ (2003). At one point, $40 \%$ of registrants in New Orleans were convicted of sodomy, which was typically used to target male and female prostitutes. Pamela Coyle, 400 Sex Offenders in Region; Web Site Lists Many in N.O.: $44 \%$ Probably Prostitutes, New ORLEANs Times-PicaYUne, May 2, 2000, at A1.

${ }^{374}$ In invalidating Texas's position, the Lawrence majority observed that "laws once thought necessary and proper [can] in fact serve only to oppress." Lawrence, 539 U.S. at 579; cf. Ann Althouse, Vanguard States, Laggard States: Federalism and Constitutional Rights, 152 U. PA. L. REv. 1745, 1746-48 (2004) (observing in the context of state constitutional rights the existence of "laggard" states, sovereigns that refuse to transform their norms in accord with the experience of their "vanguard" counterparts).

${ }^{375}$ Lynn A. Baker, Should Liberals Fear Federalism?, 70 U. CIN. L. REV. 433, 448 (2002). As Professor Baker points out, while Southern slavery is often attributed to states' rights-based federalism, abolitionism in fact first developed in Northern states, which struggled against national efforts to squelch such opposition. Id.; see also id. ("Diversity always entails the freedom to make wrong choices."); Klein, supra note 371, at 1568 ("Whose ox federalism gores may simply depend upon who controls Congress, the Court and each state."); cf. Young, supra note 354, at 55-56 ("One man's regulatory competition may be another's 'race to the bottom' ...."). 
ting such outlier positions to remain isolated and discrete, they are spread throughout the land. ${ }^{376}$

\section{CONCLUSION}

This Article has addressed a unique phenomenon with expansive repercussions: the use by states of criminal convictions rendered by fellow sovereign state governments. In particular, the Article has examined two types of state laws-criminal recidivist and sex-offender registration provisions-designed to ensure continued accountability of ex-offenders, who, like their fellow citizens, enjoy the constitutional right to travel among the respective states. Though interconnection is common in the federal-state (vertical) federalism context with respect to civil $^{377}$ and criminal $^{378}$ matters alike, it has been far less so in the state-state (horizontal) federalism context. Among the states, it is cus-

${ }^{376}$ According to Madison, federalism was created with such potentialities for state extremism in mind. Rather than nullifying such laws, federalism ideally allowed them to remain localized to specific states:

The influence of factious leaders may kindle a flame within their particular States but will be unable to spread a general conflagration through the other States .... A rage for paper money, for an abolition of debts ... or for any other improper or wicked project, will be less apt to pervade the whole body of the Union than a particular member of it.... In the extent and proper structure of the Union, therefore, we behold a republican remedy for the diseases most incident to republican government.

The Federalist No. 10, at 79 (James Madison) (Clinton Rossiter ed., 1961).

${ }^{377}$ See, e.g., Kahn v. INS, 36 F.3d 1412, 1416 (9th Cir. 1994) (Kozinski, J., dissenting) (noting that the U.S. Bankruptcy Code relies on state law for identification of the bankrupt's assets, that the U.S. Tax Code relies on state property law, and that the U.S. Social Security system relies upon state law definitions of marriage); 28 U.S.C. $\S$ 1346 (b) (2002) (incorporating state tort law into the Federal Tort Claims Act). Moreover, as noted, in the common law context, Erie requires the application of state substantive law in federal civil diversity suits. See supra notes 172-73 and accompanying text.

${ }^{378}$ See, e.g., 18 U.S.C. $\$ 922(\mathrm{~g})(1)$, (9) (2000) (making it a federal crime to possess a firearm after being convicted of state felonies and selected misdemeanors). See generally Wayne A. Logan, Creating a "Hydra in Government": Federal Recourse to State Law in Crime Fighting, 86 B.U. L. REV (forthcoming 2006) (surveying a variety of instances of federal use of state criminal laws to effectuate federal criminal justice goals). On the other hand, federal authorities often expressly eschew reliance on state criminal laws and policies. Most notably, in instances of concurrent jurisdiction, in deciding whether or not to indict for a federal capital crime, federal prosecutors need not defer to the anti-death-penalty views of states. See U.S. DEP'T OF JUSTICE, U.S. ATTORnEYs' MANUAL § 9-10.070 (2001), available at http://www.usdoj.gov/usao/eousa/foia_ reading_room/usam/title9/10mcrm.htm\#9-10.070; $c f$. United States v. Sampson, 300 F. Supp. 2d 278, 283 (D. Mass. 2004) (imposing a death sentence on a resident of Massachusetts, a non-capital jurisdiction, and designating that the execution take place in New Hampshire, which authorizes the death penalty). 
tomary to see more competition than cooperation, ${ }^{379}$ and a selfconscious fealty to the concept of independent and autonomous rule.

As the discussion here makes clear, however, states have over time shown an increasing willingness to use one another's criminal law dispositions, prompted by their unremitting desire to expand the bounds of crime control. In doing so, they model a game-theoretic form of iterated strategic coordination based on common interests, ${ }^{380}$ rather than a standardized one-shot prisoners' dilemma model based on conflicting competitive interests. ${ }^{381}$ Furthermore, the very process of interconnection undercuts the generally accepted wisdom that a sovereign's criminal laws have no effect beyond its borders. ${ }^{382}$ Recidivist and registration laws most certainly do have extraterritorial legal effects, on a daily basis significantly impacting the lives of ex-offenders who immigrate from one state to another.

Beyond its theoretical ramifications, interconnection has a variety of practical consequences. Borrowing one another's criminal law outcomes fulfills a basic evidentiary need for state justice systems, enabling them to effectuate their recidivist and registration regimes with information provided by other states. In addition, interconnection provides states with an opportunity to learn how their fellow sovereigns address anti-social behavior, which ideally affords them a salutary opportunity for self-analysis and evolutionary change.

Yet, at the same time, interconnection indisputably creates significant practical challenges. States must undertake the unusual task of interpreting the criminal laws and records of their fellow sovereigns, a

379 See generally COMPETITION AMONG STATES AND LOCAL GOVERNMENTS: EFFICIENCY AND EQUiTY In AMERICAN FEDERALISM (Daphne A. Kenyon \& John Kincaid eds., 1991) (discussing interstate competitiveness in a variety of contexts).

380 See ERIC RASMUSEN, GAMES AND INFORMATION: AN INTRODUCTION TO GAME THEORY 29-31 (3d ed. 2001) (discussing coordination games, in which parties have common interests that can be achieved only through coordinated strategies). On coordination games more generally, see RUSSELL W. COOPER, COORDINATION GAMES: COMPLEMENTARITIES AND MACROECONOMICS (1999); Duncan Snidel, Coordination Versus Prisoners' Dilemma: Implications for International Cooperation and Regimes, 79 AM. POL. SCI. REV. 923, 931-33 (1985).

381 See Herbert Gintis, Game Theory Evolving: A Problem-Centered IntroDUCTION TO MODELING STRATEGIC INTERACTION 19 (2000) (discussing this phenomenon).

382 See, e.g., Huntington v. Attrill, 146 U.S. 657, 669 (1892) (observing that state criminal laws lack "force of themselves beyond the jurisdiction of the State which enacts them"); $c f$. People v. Betts, 103 P.3d 883, 886 (Cal.) ("It long has been established that a state will entertain a criminal proceeding only to enforce its own criminal laws, and will not assume authority to enforce the penal laws of other states or the federal government ...."), cert. denied, 125 S. Ct. 2949 (2005). 
difficult and resource-intensive enterprise. For their part, exoffenders, while not typically trained in the law, must fathom foreign laws and records, and they often suffer unequal treatment compared to other similarly situated individuals.

Interconnection also has potentially troublesome policy-based ramifications. Very often, the borrowing that states undertake assumes the form of substitution; although not compelled to do so, states permit foreign criminal law norms to take the place of their own. As a result, a key advantage of federalism is undermined: its service to democratic pluralism and capacity to reflect local values. Interconnection can thus contribute to the development of a criminal law orthodoxy, which, when foreign laws embody draconian, illconceived practices or outdated social mores, can bear troublesome historically and geographically contingent consequences. Rather than isolating criminal justice experiments to the confines of individual states, interconnection replicates them across the nation as a whole, over time possibly contributing to a race-to-the-bottom of harshness.

Despite these concerns, state interconnection is likely to increase in coming years, given Americans' ever-growing anxiety over crime ${ }^{383}$ and criminal offenders (sex offenders in particular). ${ }^{384}$ Moreover, to the extent interconnection promotes greater uniformity and cooperation, states can be expected to find appeal in the increased efficiency it promises. ${ }^{385}$

${ }^{383}$ See Michael Tonry, Rethinking Unthinkable Punishment Policies in America, 46 UCLA L. REV. 1751, 1752 (1999) (arguing that "moral panics" about crime have led to draconian punishments and increased punitiveness in contemporary American society).

${ }^{384}$ See, e.g., People v. Franklin, 975 P.2d 30, 34 (Cal. 1999) ("California has a continuing interest in tracking sex offenders outside state boundaries, to assure continuing surveillance and notification to interested authorities in other states."); id. at 36 (Brown, J., dissenting) ("Given the 'continuing threat to society' posed by sex offenders, official knowledge of their whereabouts is imperative. That concern does not significantly diminish when they cross state lines ...." (citation omitted)).

${ }^{385}$ See David Charny, Competition Among Jurisdictions in Formulating Corporate Law Rules: An American Perspective on the "Race to the Bottom," in the European Communities, 32 HARV. INT'L L.J. 423, 436 (1991) (noting that interjurisdictional uniformity "saves the decisionmakers and transactors the costs of having to develop and learn a multiplicity of rules"); Ribstein \& Kobayashi, supra note 361, at 132 (noting that uniform laws can reduce inconsistency costs). Indeed, Congress has become increasingly interested in making the nation's network of disparate state-based sex-offender registration systems more uniform and integrated. See Josh Gerstein, N.Y.'s Senators Offer 2 Visions on One Subject, N.Y. Sun, Aug. 2, 2005, at 1 (quoting U.S. Senator Charles Schumer's statement that "[c] onvicted sex offenders shouldn't be able to escape the letter of the law just by moving across state lines"). 
By the same token, as the laws continue to evolve, it is unlikely that the ills associated with interconnection will be redressed, given the evident lack of institutional incentives. Of course, foreign states, where the predicate convictions occurred, will be unlikely to complain about ex-offenders that are now out of their hair, and, so far as they are concerned, the subsequent registration or sentencing decisions of other states are externalities that have no direct impact on them. For forum states, on the other hand, interconnection carries implementation costs, requiring expenditures in corrections (for example, prison beds and maintaining registration and perhaps communitynotification systems) and the justice system (for example, court time and resources). However, just as states do not usually complain about the increasing "federalization" of crime, ${ }^{386}$ they are unlikely to get upset over the more subtle, yet more pervasive, incursion by other states. States will very likely consider the resources expended to be simply a cost of doing business amid the nation's ongoing "get tough" political atmosphere, which ex-offenders are ill-equipped to politically combat. ${ }^{387}$ Finally, the judiciary will not likely have cause for concern, given that no winning issues of constitutional magnitude present themselves. ${ }^{388}$

This Article has sought to highlight a pervasive phenomenon that to date has eluded the attention of courts and commentators. Rather than focusing on the typical federalism concern of federal-state relations, and attendant worry of federal usurpation of state criminal justice prerogatives, discussion has centered on the far more common (and practically important) interrelations between states, which on a daily basis process the vast majority of criminal offenders in America. Much as states are increasingly now engaged in dialogues regarding the interpretation of their respective constitutions, ${ }^{389}$ so too are they

386

See Michael A. Simons, Prosecutorial Discretion and Prosecution Guidelines: A Case Study in Controlling Federalization, 75 N.Y.U. L. REV. 893, 908 (2000) (noting that "few local lawmakers or prosecutors are heard complaining about federalization").

${ }^{387}$ See supra notes 283-85 and accompanying text.

388 See supra notes 286-321 and accompanying text.

389 For discussion of this phenomenon, see Symposium, Dual Enforcement of Constitutional Norms, 46 WM. \& MARY L. REV. 1219 (2005). As Professors Garnder and Rossi observed in introducing the symposium, "State constitutions have entered into a new interpretative era. ... A borrowing mentality [has] emerged, as courts look[] outside of their jurisdictional territories to state constitutions to fill gaps in constitutional interpretation." James A. Gardner \& Jim Rossi, Foreword: The New Frontier of State Constitutional Law, 46 WM. \& MARY L. REV. 1231, 1231 (2005); see also id. at 1232 (noting the recent origins of a new "collective enterprise of democratic self-governance"); $c f$. Michael C. Dorf \& Charles F. Sabel, A Constitution of Democratic Experimentalism, 98 COLUM. 
reaching out to one another in their criminal justice missions. In doing so, however, they are compelled to reconcile federalism's inherent age-old tension between comity and autonomy. How they go about this, and the outcomes they reach, will have a significant impact on criminal justice policy and practice in the years to come.

L. REV. 267, 434 (1998) (asserting that federalism promotes a salutary "experimentalist collaboration between the states and the federal government"). 